


\section{Water-Quality Trends for the Cheyenne and Moreau Rivers, Cheyenne River Indian Reservation, South Dakota, 1972-94}

By Allen J. Heakin

Water-Resources Investigations Report 98-4092 
U.S. Department of the Interior

Bruce Babbitt, Secretary

\section{U.S. Geological Survey}

Thomas J. Casadevall, Acting Director

The use of firm, trade, and brand names in this report is for identification purposes only and does not constitute endorsement by the U.S. Geological Survey.

Rapid City, South Dakota: 1998

For additional information, write to:

District Chief

U.S. Geological Survey

1608 Mt. View Road

Rapid City, SD 57702

Copies of this report can be purchased from:

\section{U.S. Geological Survey}

Branch of Information Services

Box 25286

Denver, CO 80225-0286 


\section{CONTENTS}

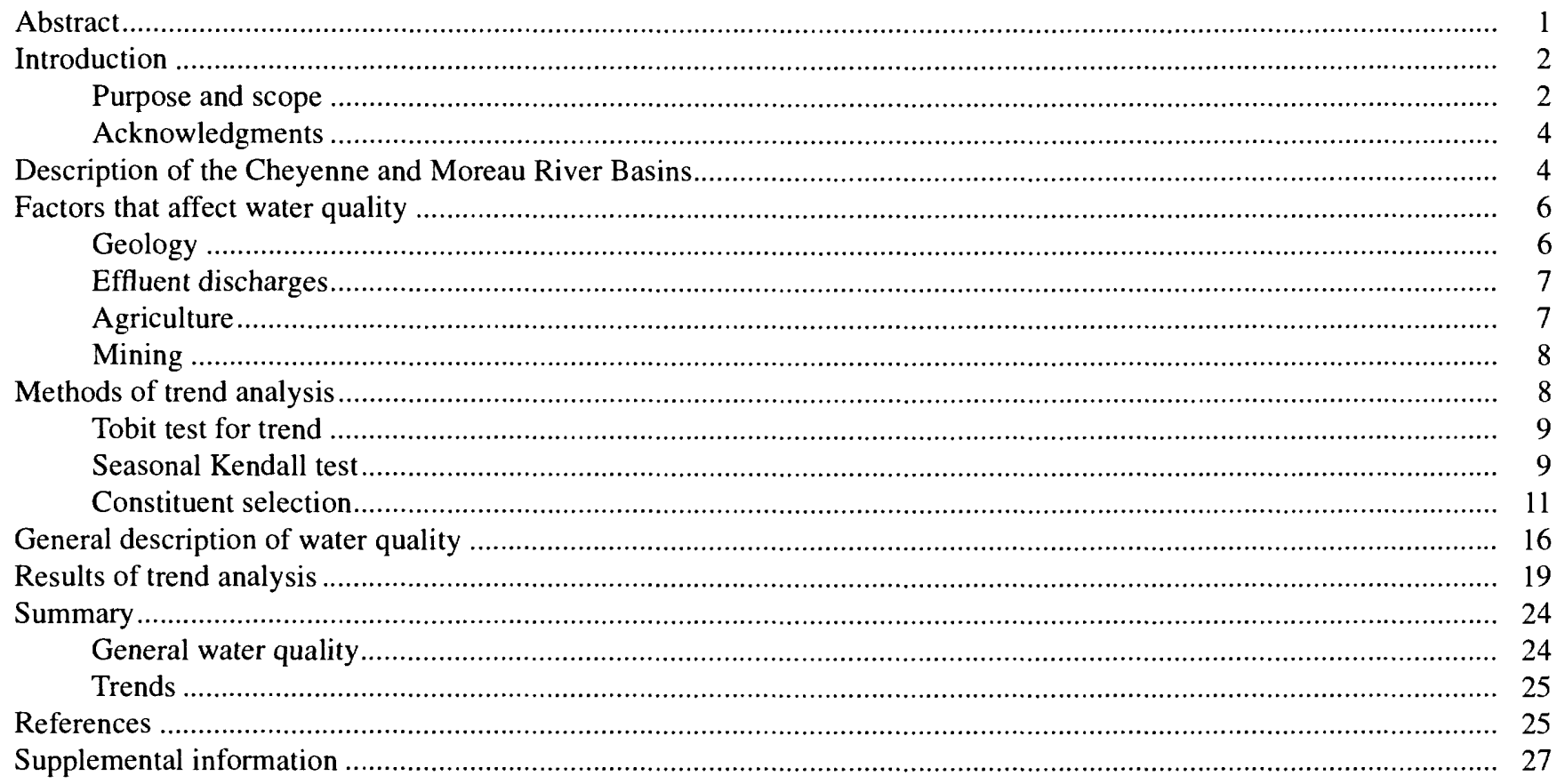

\section{ILLUSTRATIONS}

1. Map showing location of the Cheyenne River Indian Reservation showing streamflowgaging stations for which long-term water-quality data are available

2. Map showing location of major tributaries to the Cheyenne and Moreau Rivers................................................ 5

3. Graph showing mean monthly streamflow for station 06439300, Cheyenne River at Cherry Creek, and station 06360500, Moreau River near Whitehorse (1972-94).

4. Graphs showing relationship between dissolved solids and streamflow and suspended sediment and streamflow for Cheyenne River at Cherry Creek and Moreau River near Whitehorse.

5. Graph showing dissolved mercury concentrations for Cheyenne River at Cherry Creek, Moreau River near Whitehorse, and all other South Dakota NASQAN stations

6-19. Boxplots showing ranges in:

6. Specific conductance values for Cheyenne River at Cherry Creek and Moreau River near Whitehorse

7. $\mathrm{pH}$ values for Cheyenne River at Cherry Creek and Moreau River near Whitehorse.

8. Concentrations of fecal coliform for Cheyenne River at Cherry Creek and Moreau River near Whitehorse

9. Sodium-adsorption values for Cheyenne River at Cherry Creek and Moreau River near Whitehorse ......... 32

10. Concentrations of dissolved sulfate for Cheyenne River at Cherry Creek and Moreau River near Whitehorse

11. Concentrations of dissolved chloride for Cheyenne River at Cherry Creek and Moreau River near Whitehorse

12. Concentrations of dissolved solids for Cheyenne River at Cherry Creek and Moreau River near Whitehorse

13. Concentrations of dissolved ammonia as nitrogen for Cheyenne River at Cherry Creek and Moreau River near Whitehorse 


\section{ILLUSTRATIONS-Continued}

14. Concentrations of total nitrogen for Cheyenne River at Cherry Creek and Moreau River near Whitehorse .....

15. Concentrations of total phosphorus for Cheyenne River at Cherry Creek and Moreau River near Whitehorse

16. Concentrations of dissolved arsenic for Cheyenne River at Cherry Creek and Moreau River near Whitehorse

17. Concentrations of dissolved manganese for Cheyenne River at Cherry Creek and Moreau River near Whitehorse ......

18. Concentrations of dissolved selenium for Cheyenne River at Cherry Creek and Moreau River near Whitehorse

19. Concentrations of suspended sediment for Cheyenne River at Cherry Creek and Moreau River near Whitehorse

20-33. Graphs showing temporal trends:

20. In specific conductance for flow-adjusted values, using the seasonal Kendall test

21. In $\mathrm{pH}$ for flow-adjusted values, using the seasonal Kendall test.

22. In fecal coliform for raw concentrations, using the seasonal Kendall test.

23. In sodium-adsorption ratio for flow-adjusted values, using the seasonal Kendall test......

24. In dissolved sulfate for flow-adjusted concentrations, using the seasonal Kendall test.

25. In dissolved chloride for flow-adjusted concentrations, using the seasonal Kendall test

26. In dissolved solids for flow-adjusted concentrations, using the seasonal Kendall test.....

27. In dissolved ammonia as nitrogen for flow-adjusted concentrations, using the seasonal Kendall test.

28. In total nitrogen for flow-adjusted concentrations, using the seasonal Kendall test

29. For the Cheyenne River in total phosphorus for raw concentrations, using the Tobit test, and for the Moreau River for flow-adjusted concentrations, using the seasonal Kendall test

30. For the Cheyenne River in dissolved arsenic for raw concentrations, using the Tobit test, and for the Moreau River for flow-adjusted concentrations, using the seasonal Kendall test

31. In dissolved manganese for raw concentrations, using the Tobit test.....

32. For the Cheyenne River in dissolved selenium for raw concentrations, using the Tobit test, and for the Moreau River for raw concentrations, using the seasonal Kendall test.

33. In suspended sediment for flow-adjusted concentrations, using the Kendall test

\section{TABLES}

1. Water-quality criteria, standards, or recommended limits for selected properties or constituents

2. Summary statistics for water-quality data used to develop boxplots for station 06439300 ,

Cheyenne River at Cherry Creek

3. Summary statistics for water-quality data used to develop boxplots for station 06360500, Moreau

River near Whitehorse

4. Comparison of water quality for station 06439300. Cheyenne River at Cherry Creek, to criteria, standards, or recommended limits

5. Comparison of water quality for station 06360500, Moreau River near Whitehorse, to criteria, standards, or recommended limits

6. Results of Seasonal Kendall and Tobit test for trend on water-quality data for Cheyenne River at Cherry Creek.

7. Results of Seasonal Kendall and Tobit test for trend on water-quality data for Moreau River near Whitehorse

8. Summary statistics for water-quality data used for the analysis of trend at Cheyenne River at Cherry Creek.

9. Summary statistics for water-quality data used for the analysis of trend at Moreau River near Whitehorse 


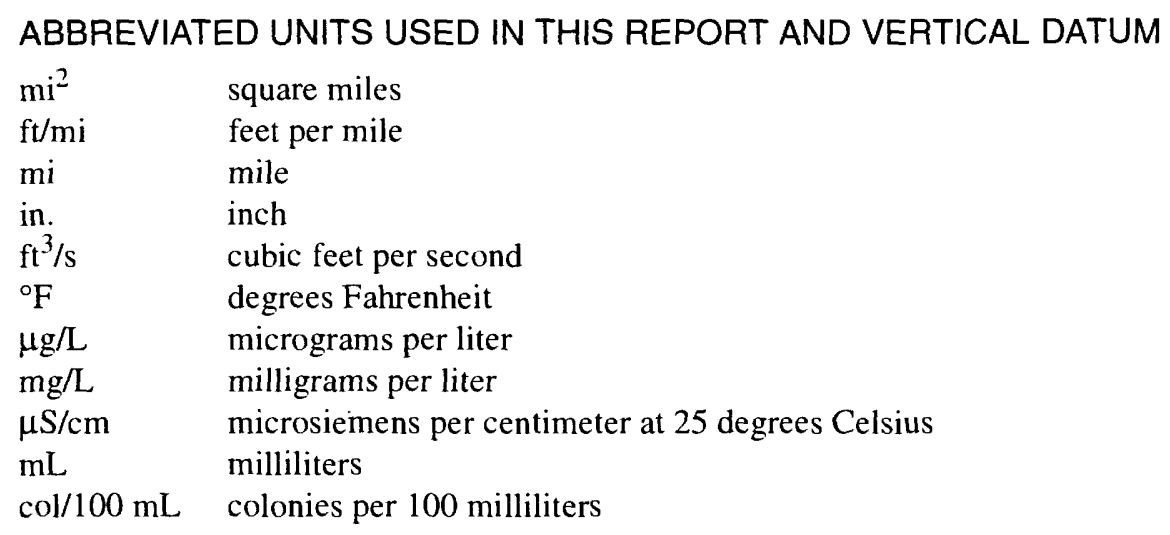

Sea level: In this report, "sea level" refers to the National Geodetic Vertical Datum of 1929 (NGVD of 1929)—a geodotic datum derived from a general adjustment of the first-order level nets of both the United States and Canada, formerly called Sea Level Datum of 1929. 



\title{
Water-Quality Trends for the Cheyenne and Moreau Rivers, Cheyenne River Indian Reservation, South Dakota, 1972-94
}

\author{
By Allen J. Heakin
}

\section{ABSTRACT}

This report describes temporal changes in water quality at one site on each of the two major rivers traversing the Cheyenne River Indian Reservation. The data were collected between 1972-94 at stations on the Cheyenne River, which forms the southern boundary of the Reservation, and on the Moreau River to the north. Waterquality constituents analyzed include field parameters (specific conductance, $\mathrm{pH}$, and bacterial concentration), common ions, nutrients, and selected trace elements.

Boxplots are used to display monthly distributions of concentrations for selected waterquality constituents at each station. Water-quality data are compared to standards for domestic water supply and drinking water, even though they are not assigned as beneficial uses of surface water for either the Cheyenne or Moreau Rivers. Comparisons also are made to standards and criteria that have been developed to support the beneficial uses assigned for the rivers at these stations, which include aquatic life value for fisheries, immersion recreation, wildlife propagation and stock watering, and irrigation.

No primary drinking-water standards (maximum contaminant levels-MCL's) for the constituents considered were exceeded for either river. However, the primary standard for total phosphorus entering a reservoir was frequently equalled or exceeded for both rivers.
Secondary standards (secondary maximum contaminant levels-SMCL's) for drinking-water supplies for dissolved sulfate were frequently equalled or exceeded at both the Cheyenne and Moreau River stations. Various exceedances of secondary standards for dissolved solids, fecal coliform bacteria, $\mathrm{pH}$, and manganese also were noted.

The standard for irrigation for sodiumadsorption ratio was equalled or exceeded on ?e at the Cheyenne River station and frequently at the Moreau River station. The standard for specific conductance was frequently equalled or excesded at both stations.

Standards for wildlife propagation and stock watering generally were met. Standards for warmwater permanent and marginal fish propagation were frequently exceeded for suspended sediment. Ammonia standards at both the Cheyenne and Moreau River stations were frequently equalled or exceeded.

The standard for chronic toxicity of selenium for aquatic life for fisheries was frequently equalled or exceeded at the Cheyenne River station, the standard for acute toxicity of selenium was not equalled or exceeded at either station. The standard for fecal coliform for immersion recreation waters was occasionally equalled or exceeded at the Cheyenne River station and frequently equalled or exceeded at the Morecu River station. 
Selected water-quality constituents collected at each station were analyzed for trend using both the Seasonal Kendall and Tobit test methods. Whenever possible, the results of the Seasonal Kendall test on flow-adjusted concentrations were used to define trends. The trend test that provided the most statistically significant $\mathrm{p}$ value was selected. Trends with p-values less than or equal to 0.050 were considered to be statistically significant.

Trend analysis for water-quality data collected from the Cheyenne River at Cherry Creek showed that of the 14 constituents considered, five had trends that were determined to be statistically significant, five were not statistically significant, and four showed no trend. Of the five statistically significant trends, three were increasing, and two were decreasing. Increasing trends included dissolved sulfate, dissolved chloride, and dissolved solids. The two statistically significant decreasing trends included dissolved arsenic and dissolved manganese. Previous investigations have shown that elevated concentrations of dissolved arsenic in the Cheyenne River are linked to mining practices in the Black Hills. The statistically significant decreasing trend in dissolved arsenic probably results from changes made in the methods used for the disposal of mine tailings.

Trends for the Moreau River near Whitehorse showed that, of the 14 constituents considered, one was determined to be statistically significant, and 10 were not statistically significant, and three showed no trend. The only statistically significant trend showed a decrease in dissolved manganese.

\section{INTRODUCTION}

Drinking water is a scarce and precious resource for the residents of the Cheyenne River Indian Reservation. Many residents obtain their drinking water from municipal water-supplies that utilize Lake Oahe as a source. However, a significant number of people in outlying areas obtain drinking water from other sources.
Water quality is known to be poor in some areas of the Reservation. A reconnaissance study conducted by the U.S. Geological Survey (USGS), in cooperation with the Bureau of Indian Affairs, determined that dissolved solids, nitrate, sodium, sulfate, iron, and manganese were present naturally in some locations at concentrations exceeding drinking-water standards established by the U.S. Environmental Protection Agency (USEPA) (Howells, 1979).

Members of the Cheyenne River Sioux Tribe are concerned about potential health hazards of poorquality water. The Tribe is planning to develop a set of standards to protect the quality of surface-water resources on the Reservation.

Planning for long-term water supplies requires that the Tribe develop a set of standards to manage their water resources. A study of water-quality trends for the Cheyenne and Moreau Rivers was con lucted by the USGS in cooperation with the Cheyenne River Sioux Tribe. Results will provide the Tribe w'ith the information necessary to evaluate natural and anthropogenic effects on surface-water quality and will assist the Tribe in the development of surface-water standards.

\section{Purpose and Scope}

The primary purpose of this report is to describe temporal trends in water quality for the Cheyenne and Moreau Rivers on the Cheyenne River Indian Reservation. Trend analyses were performed using water-quality data for USGS streamflow-gaging stations 06439300, Cheyenne River at Cherry Creek, and 06360500, Moreau River near Whitehorse (fig. 1), which were operated as part of the National StreamQuality Accounting Network (NASQAN). Boxplots are used to visually display the data distribution for each selected constituent. Data for the Cheyenne and Moreau Rivers apply for the period 1972-94. Because trends in constituent concentrations are examined for only one site on each river, it is beyond the scope of this report to determine how water quality is changing in a particular reach of the river, or for most constituents analyzed, to identify causes of the changes.

Water-quality data also are compared to standards and criteria promulgated by the USEPA and the South Dakota Department of Environment and Natural Resources (SDDENR). This is done to determine the frequency with which selected constituents have exceeded standards established for assigned beneficial uses. Water-quality data also are compared to 

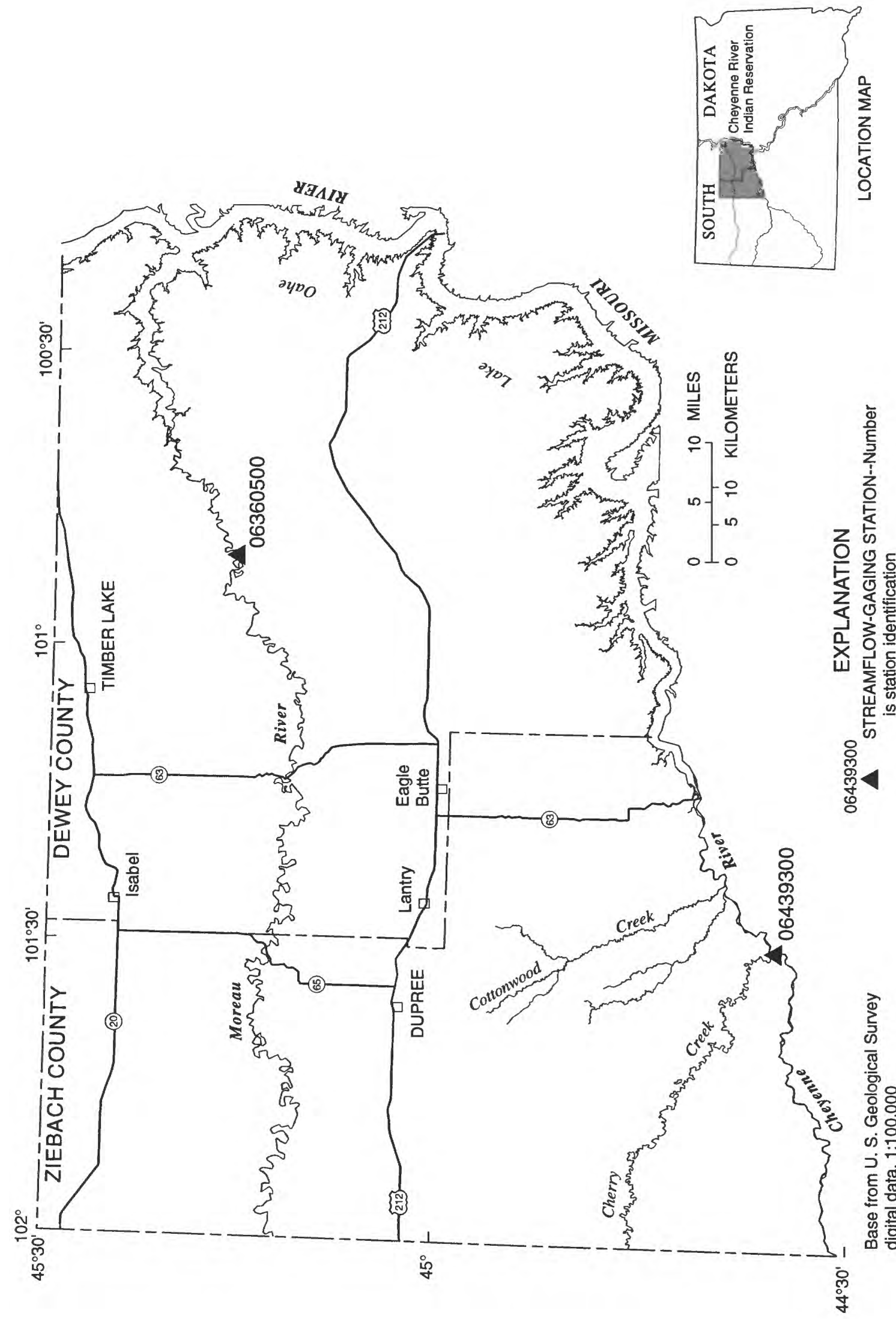
drinking-water standards that are not assigned as beneficial uses of surface water of the Cheyenne or Moreau Rivers by the SDDENR. These comparisons are made to assess general water-quality conditions for both rivers at the sampling stations. Selected water-quality constituents include field parameters (specific conductance, $\mathrm{pH}$, and bacterial concentration), common ions, nutrients, and selected trace elements.

Data collected by the USGS prior to 1979 were collected and analyzed according to protocols summarized by Rainwater and Thatcher (1960). Data collected after 1979 were collected and analyzed according to USGS protocols summarized by Skougstad and others (1979) and by Fishman and Friedman (1989).

\section{Acknowledgments}

The author is grateful to numerous individuals who facilitated the data compilation and statistical analyses presented in this report. Special thanks is extended to the staff of Environmental Department of the Cheyenne River Sioux Tribe, who provided support throughout this project. Special appreciation also is directed to Kathy Neitzert and Steve Sando of the USGS for their assistance.

\section{DESCRIPTION OF THE CHEYENNE AND MOREAU RIVER BASINS}

The Cheyenne and Moreau River Basins lie within the Great Plains physiographic province (Fenneman, 1946). The Cheyenne River Indian Reservation (fig. 1) lies on a gently northwest dipping flank of the Williston Basin in north-central South Dakota. The area of the Reservation is approximately $4,230 \mathrm{mi}^{2}$ and encompasses Dewey and Ziebach Counties. The topography of the Reservation is largely rolling upland that has been eroded by the Missouri River and its tributaries. Erosional processes have created a "badlands" type area known locally as "the breaks" (Howells, 1979). Elevations range from about $1,600 \mathrm{ft}$ above sea level along Lake Oahe to about $2,700 \mathrm{ft}$ above sea level at the top of Thunder Butte. About 88 percent of the land area is in native grass and is used primarily for grazing livestock.

The Cheyenne and Moreau Rivers are the largest rivers traversing the Cheyenne River Indian Reservation (fig. 1). To the east, the Reservation is bounded by Lake Oahe, which is a major impoundment on the Missouri River. The Cheyenne River forms the southern boundary of the Reservation and is the largest tributary to the Missouri River within South Dakota (drainage area of about $25,500 \mathrm{mi}^{2}$ ). The Cheyenne River originates in eastern Wyoming, flows southeast around the southern Black Hills, and then flows northeast across South Dakota to its mouth at Lake Oahe (fig. 2). In the reach from Edgemont to Wasta, the average gradient of the Cheyenne River is about $7.5 \mathrm{ft} / \mathrm{mi}$. Downstream from Wasta, the average gradient is about $6 \mathrm{ft} / \mathrm{mi}$. The Cheyenne River is joined by the Belle Fourche River approximately $15 \mathrm{mi}$ southwest of the Reservation boundary. The Belle Fourche River flows northeast in Wyoming and then flows southeast around the northern Black Hills to its confluence with the Cheyenne River. The Belle Fourche River is the largest tributary to the Cheyenne River and drains about one-third of the entire Cheyenne River Basin. The average gradient of the Belle Fourche River downstream from Belle Fourche is about $6 \mathrm{ft} / \mathrm{mi}$.

The climate of the Cheyenne River Basin is characterized as semi-arid continental, with large variations in precipitation and temperature. The high plains of eastern Wyoming are relatively dry. During the period 1931-90, the mean annual precipitation for the part of Cheyenne River Basin located in Wyoming was about 14 in., and the mean annual temperature was about $46^{\circ} \mathrm{F}$ (U.S. Department of Commerce, 1990a).

Orographic effects induced by the Black Hills are responsible for dramatic spatial changes in climate within western South Dakota. As elevation increases, precipitation generally increases and temperature generally decreases. Precipitation also varies spatially within the Black Hills, from a mean annual value of less than 12 in. in the southwest, to a maximum of more than 29 in. in the north. During the same period, the mean annual precipitation for the part of the Belle Fourche River Basin located in Wyoming was about $16 \mathrm{in}$, and the mean annual temperature was about $44^{\circ} \mathrm{F}$, based on climate data collected at Moorcroft and Sundance (U.S. Department of Commerce, 1990a).

Mean monthly streamflow during 1972-94 at station 06439300, Cheyenne River at Cherry Creek increases from about $280 \mathrm{ft}^{3} / \mathrm{s}$ in February to about $1,650 \mathrm{ft}^{3} / \mathrm{s}$ in March, mainly in response to snowmelt (fig. 3). The maximum mean monthly streamflow is about $2,000 \mathrm{ft}^{3} / \mathrm{s}$ in May, which coincides with the period of greatest rainfall. Monthly mean streamflow drops throughout the remainder of the year to a low of about $100 \mathrm{ft}^{3} / \mathrm{s}$ in January. 


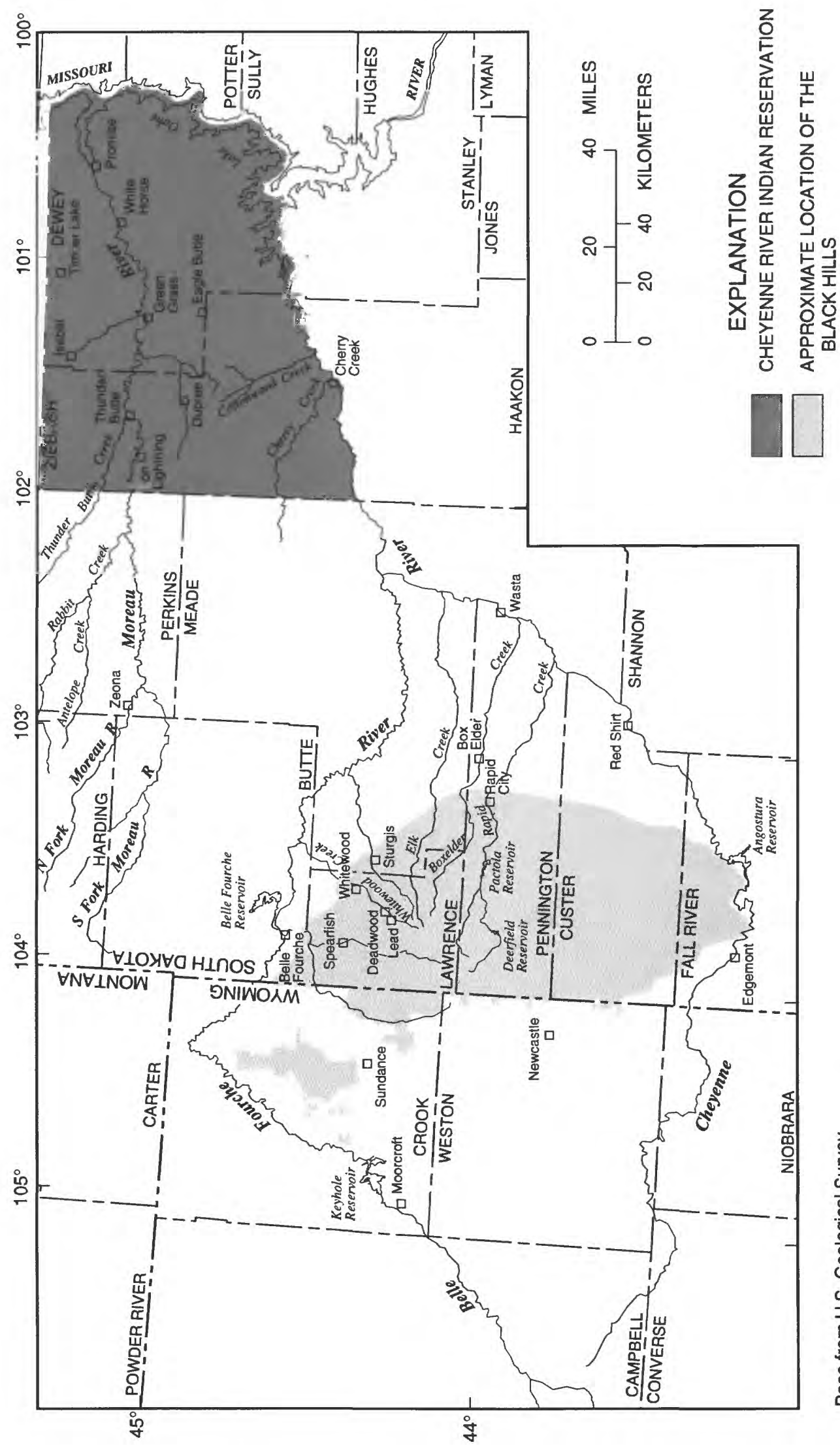

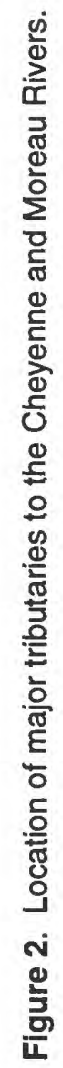




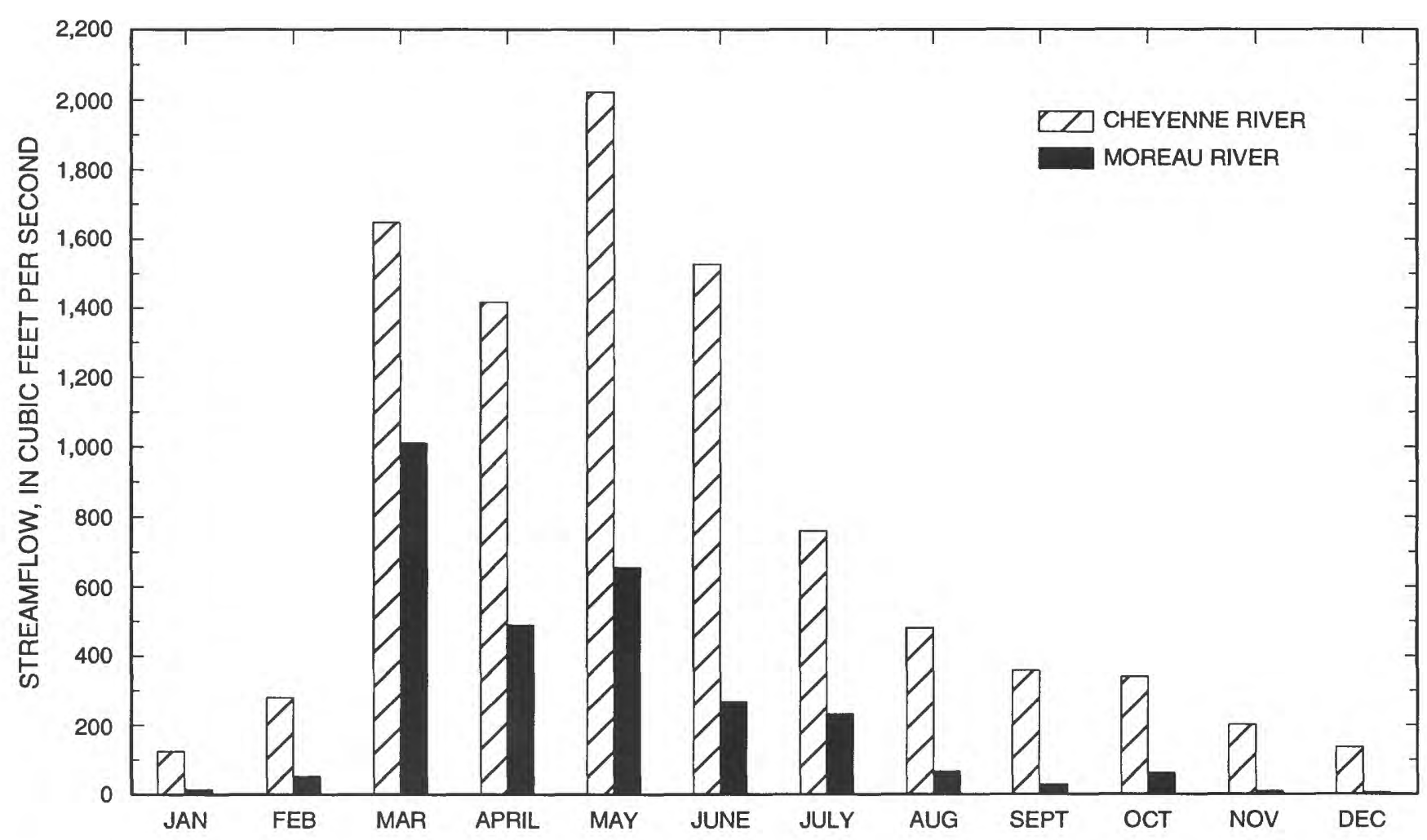

Figure 3. Mean monthly streamflow for station 06439300, Cheyenne River at Cherry Creek, and station 06360500, Moreau River near Whitehorse (1972-94).

The Moreau River originates in northwestern South Dakota, just east of the Montana border. It has a drainage area of nearly $5,000 \mathrm{mi}^{2}$ and flows approximately 180 river miles in an easterly direction, at a gradient of about $4 \mathrm{ft} / \mathrm{mi}$, to its mouth at Lake Oahe.

The Moreau River Basin has much less spatial variation in precipitation and temperature than the Cheyenne River Basin. During 1961-90, the mean annual precipitation at Zeona (fig. 2) was about 16.4 in., and the mean annual precipitation at Dupree, located approximately $100 \mathrm{mi}$ east, was about $15.4 \mathrm{in}$. During the same period, the mean annual temperatures at Zeona and Dupree were 46.1 and $45.3^{\circ} \mathrm{F}$, respectively (U.S. Department of Commerce, 1990b).

Mean monthly streamflow during 1972-94 at station 06360500, Moreau River near Whitehorse, increases from about $13 \mathrm{ft}^{3} / \mathrm{s}$ in January to about $1,000 \mathrm{ft}^{3} / \mathrm{s}$ in March, as a result of increased snowmelt (fig. 3). Mean monthly streamflow decreases to about $500 \mathrm{ft}^{3} / \mathrm{s}$ in April and then rises again in May to about $650 \mathrm{ft}^{3} / \mathrm{s}$, as a result of increased rainfall. Monthly mean streamflow decreases steadily throughout the remainder of the year to a low of about $5 \mathrm{ft}^{3} / \mathrm{s}$ in December.

\section{FACTORS THAT AFFECT WATER QUALITY}

Water quality in the Cheyenne and Moreau Rivers is affected by many natural and anthropogenic factors such as geology, effluent discharges, agricultural practices and irrigation return flows, and mining practices. The following sections describe these factors.

\section{Geology}

The Cheyenne and Belle Fourche Rivers both originate in east-central Wyoming in areas of Eoceneand Paleocene-age sedimentary rock exposures. The Paleocene-age rocks host thick, continuous coal seams. The two rivers flow around the domal Black Hills uplift where mostly metasedimentary rocks of Precambrian age, carbonate rocks of Paleozoic age, and mixed sandstones and shales of early Mesozoic age are exposed. The two rivers stay within the outcrop belts of Late Cretaceous-age shales and chalks as they flow around the uplift. The Cretaceous-age shales can be a source 
of sulfate and selenium. The rivers continue flowing eastward across flat-lying outcrops of Cretaceous-age Pierre Shale, which is a marine shale that contains high concentrations of iron, manganese, and limestone concretions. The Pierre Shale also is characterized by an abundance of low permeability bentonite clay. As a result, exposures of this unit are prone to high runoff during periods of intense or extended rainfall. Earlier flood-plain levels of the rivers are marked by Late Tertiary- and Quaternary-age gravel terraces, which are generally about $1 \mathrm{mi}$ wide and are now perched above the current alluvial flood plains.

Surficial geology of the Moreau River Basin consists of Late Cretaceous- and Tertiary-age shale and sandstone rocks with lesser areas of Tertiary- and Quaternary-age terrace gravels and alluvial deposits. The North Fork of the Moreau River is underlain by the Paleocene-age Fort Union Formation and has exposures of the Eocene- and Oligocene-age White River Group. It then flows across Late Cretaceous-age Hell Creek Formation mudstones and sandstones just upstream from the confluence with the South Fork of the Moreau River.

The South Fork of the Moreau River drains lands underlain by the Pierre Shale, Fox Hills Sandstone, and Hell Creek Formation as it flows towards its confluence with the North Fork. The Late Cretaceous-age Fox Hills Sandstone is very fine grained and consists of a thinly bedded sequence of claystone, siltstone, and sandstone beds (Howells, 1979).

The Moreau River flows eastward across the Pierre Shale between large ridges capped by the Fox Hills Sandstone, enroute to the Missouri River. Earlier flood-plain levels of the Moreau River and its tributaries are marked by gravel terraces now exposed by episodic erosion. The Moreau River flood plain is about one-half mile wide and is underlain by Quaternary-age alluvium.

\section{Effluent Discharges}

Sewage effluent can enter the Cheyenne and Moreau Rivers from several sources. Individual homes and small communities are located within the flood plains of these rivers and their tributaries, and they rely on individual septic systems to treat wastes. The SDDENR estimates that 25 percent of households utilize onsite wastewater-treatment systems to meet their sewage disposal needs. Because most of the communities are small, often less than 100 people, the construction of central collection and treatment facilities is unlikely due to cost (South Dakota Department of Environment and Natural Resources, 1996). Larger towns and villages generally use waste-treatment lagoons and settling ponds to treat their waste material, or employ municipal wastewater-treatment plants that discharge treated effluent directly into streams and rivers. Such communities are required to obtain effluent discharge permits from the SDDENR, authorizing them to discharge treated effluent. Permitted communities (tribal and nontribal) are required by SDDENR to routinely monitor the quality of their effluent and report the results to the State.

\section{Agriculture}

Ranching is the largest agricultural activit:" within the Cheyenne and Moreau River Basins. Beef cattle and sheep are the primary types of livestock. Information available from the U.S. Department of Agriculture (1976) indicates that approximately 76 percent of farm and ranch income in South Dakota was derived from the sale of livestock. Stock ponds and dugouts constructed to catch spring runoff, as well as shallow wells, provide most of the water for livestock. The U.S. Geological Survey (1975) estimated that during dry years, stock ponds can reduce the runoff from parts of the plains by more than 30 percent.

Winter wheat, alfalfa, spring wheat, and oats are the main crops (South Dakota Crop and Livestock Reporting Service, 1985). Hay crops include alfalfa and crested wheatgrass. Poor soils, low precipitation, and fairly steep topographic relief account for the minimal areal extent of farmlands.

Several irrigation areas exist within the Cheyenne and Moreau River Basins. The Bureau of Reclamation operates five reservoirs (Keyhole, Pelle Fourche, Angostura, Deerfield, and Pactola) with in the Cheyenne River Basin for storage of irrigation water (fig. 2). Numerous other smaller, privately owned impoundments also provide storage for irrigation. Instream flows of numerous tributaries also are diverted for irrigation. In some areas, ground water is utilized for irrigation.

Effects of irrigation return flows on water quality, bottom sediment, and biota have been documented for the Angostura and Belle Fourche irrigation units. A reconnaissance investigation for the Angostura Reclamation Unit (Greene and others, 1990, 
p. 55) concluded that "... there appeared to be minor differences between concentrations of trace elements in water of the Cheyenne River upstream of irrigated land and in water downstream from all irrigation return flow." A reconnaissance investigation for the Belle Fourche Reclamation Project (Roddy and others, 1991) concluded that the concentration of some dissolved constituents increased as a result of irrigation practices. Concentrations of trace elements were small, however, in comparison to relevant water-quality criteria, standards, or recommended limits.

\section{Mining}

Water quality within the Cheyenne River Basin is known historically to be affected by gold-mining activities in the Black Hills area. Gold was discovered near Custer, South Dakota, in 1875, initiating one of the largest industries in western South Dakota. As of 1991, five large-scale, open-pit, heap-leach mines and the Nation's largest underground gold mine were located within the Black Hills. In addition to gold, these mines produce other precious metals.

Between 1876 and 1977, an estimated 100 million metric tons of gold-mill tailings were deposited in Whitewood Creek, which is a tributary to the Belle Fourche River (Goddard, 1989). Concentrations of arsenic and mercury have been determined to be as much as several orders of magnitude larger in sediments along Whitewood Creek and the Belle Fourche River than in background samples. Goddard (1989, p. 2) estimated that between 1920 and 1977, about 270,000 tons of arsenic were discharged into Whitewood Creek. Trace elements commonly associated with gold-mill tailings such as antimony, cadmium, copper, iron, manganese, mercury, and silver also have been shown to be present at elevated concentrations in sediment samples collected along Whitewood Creek and the Belle Fourche River (Goddard, 1989).

In 1981, a reach of Whitewood Creek and the Belle Fourche River was designated as an Interim Priority Site under the Comprehensive Environmental Response Compensation and Liability Act (CERCLA). In 1983, the site was placed on the National Priorities List by the USEPA. Goddard (1989) documented increased concentrations of various constituents in sediments deposited along Whitewood Creek, and the Belle Fourche and Cheyenne Rivers. Arsenic was identified as the most important constituent of concern; however, increased concentrations of various other constituents were documented in flood-plain sediments. In 1996, the USEPA removed the site from the National Priorities List following implementation of mitigation measures.

Periods of high streamflow created overbank deposits of contaminated sediments in the flood plains of Whitewood Creek and the Belle Fourche River (Marron, 1988). These contaminated overbank deposits may be remobilized and transf orted downstream during periods of high streamflc ' $v$. Although the discharge of tailings into Whitewoo 1 Creek ceased in 1977, effects from contaminated sed ment continue to be a cause for concern. Marron (19\&8, p. 11) estimated that the "... metal-contaminated flood-plain deposits will continue to be a source of metals to adjacent streams for centuries."

Numerous studies have been undertaken in response to persistent concerns, specifically regarding arsenic and several other trace elements within the Cheyenne River Basin. Acid mine drainage is known to exist locally near sulfide ore deposits at various locations in the Black Hills. The individual and cumulative effects of numerous other mining operctions are difficult to quantify. Active coal and bentonite clay mines, as well as abandoned uranium mines, also are present within the Cheyenne River Basin. Documentation on potential effects at various other specif c sites can be found in the literature.

\section{METHODS OF TREND ANALY?IS}

Selected water-quality constituents were analyzed for trend using both parametric and nonparametric test methods. Parametric tests for trend assume that when a water-quality constituent is regressed against time, or any other independent variable, the resulting residuals are symmetrically distributed and form a bell-shaped (normal) curve. Wl an the assumptions of normality and equal variances of data are not valid, nonparametric tests for trend may be utilized. Nonparametric tests compare ranks of data rather than the actual data values.

The inherent variability of a data set is the primary factor responsible for the resulting loss of power when a parametric test is applied to waterquality data. Power is defined as the al ility of the test to reject the null hypothesis when it is false. Other factors such as the use of censored data ("less-than" values), outliers, and data sets with multiple detection limits also diminish the power of a parametric test to 
determine trend. Because nonparametric tests are not based on the distributional assumptions of parametric tests (symmetry or normality), they also are usually more powerful than parametric tests when assumptions of normality and equal variance are violated.

A computerized statistical and graphical program developed by the USGS is used for the analysis of trend in this report (Schertz and others, 1991). The program, EStimate TREND (ESTREND), incorporates statistical methods that overcome some of the common power problems encountered when conventional statistical techniques are used to evaluate trend in water-quality data.

Results of the ESTREND program may show trends that are increasing or decreasing over time, or the results may show that data values are neither increasing nor decreasing over time and have no trend. The null hypothesis for a trend test is that there is no trend in the data over time. The outcome of the trend test requires that a decision be made to either reject or not reject the null hypothesis. If the null hypothesis is rejected, the data show a trend. Failure to reject the null hypothesis does not necessarily indicate no trend in the data, but simply that the test result fails to conclude that there is a trend.

The statistical significance of the test used for the analysis of trend can be measured by the calculation of a p-value. The p-value allows the selection of a significance level according to individual preference. For this report, trend analyses with resulting p-values of 0.050 or less are considered to be statistically significant.

Water-quality data are displayed using boxplots and are presented in the Supplemental Information section at the end of this report. The data distribution for each constituent is related to month of the year so that changes in concentration can be compared.

\section{Tobit Test for Trend}

When water-quality data are censored by more than one reporting limit, conventional nonparametric techniques used to determine trend often are unreliable. This is because the outcome of the test is subject to the value selected to represent those data that fall below the detection limit. Water-quality data containing numerous values censored at multiple reporting limits were analyzed for trend using the Tobit parametric trend test (Cohen, 1976; Cohn, 1988). Tobit uses a maximum likelihood estimation (MLE) procedure
(Cohn, 1988) to estimate the parameters of a regression model relating concentration and time. Data use $f$ in the Tobit procedure are raw concentration data (P.CD) that have not been flow-adjusted and therefore lark the power of flow-adjusted techniques.

\section{Seasonal Kendall Test}

Stream-water quality can vary seasonally, mainly in response to fluctuations in streamflow. Another cause of seasonal changes in stream-water quality can be correlated to changes in the domirant source contributing to streamflow. For example, ground-water discharges may dominate during $\mathrm{d}^{\mathrm{y}} \mathrm{y}$ seasons, while surface runoff may dominate during wet seasons. Water quality of samples collected when ground water is the dominant source can differ substantially from water quality of samples collected when the converse is true.

The Seasonal Kendall test (Hirsch and othors, 1982) was used to analyze water-quality data for both long-term and seasonal trend. The Seasonal Kerdall test is a generalization of the Mann-Kendall test (Mann, 1945; Kendall, 1975). It is a nonparametr $r$ test designed to remove the variability in water-quality data caused by seasonality. Data used in the Seasonal Kendall test may be either flow-adjusted concentration (FAC) data or RCD.

The variability of water-quality data may be flow related. Many constituents decrease in concentration with increasing streamflow, as shown in figure 4 for dissolved solids at the Cheyenne and Moreau River stations. The decreasing concentrations of disso'ved solids result from dilution at higher streamflows. Concentrations of suspended constituents typically show the opposite effect (fig. 4). The increasing concentrations of suspended sediment may result from overland runoff or from resuspension of sedimerts previously deposited. Flow-related variability in water-quality data may interfere with the analysis of trend. The use of FAC data reduces flow-related variability and thereby increases the power of the test. The FAC data are therefore preferred over RCD when attempting to accurately define trends in environmental conditions. Although the use of FAC data increases the power of the Seasonal Kendall test to determine trend, flow adjustment should not be used on data sets that contain more than about 5 percent censored data. because the resulting trend slopes could be inaccirate (Schertz, 1991). 

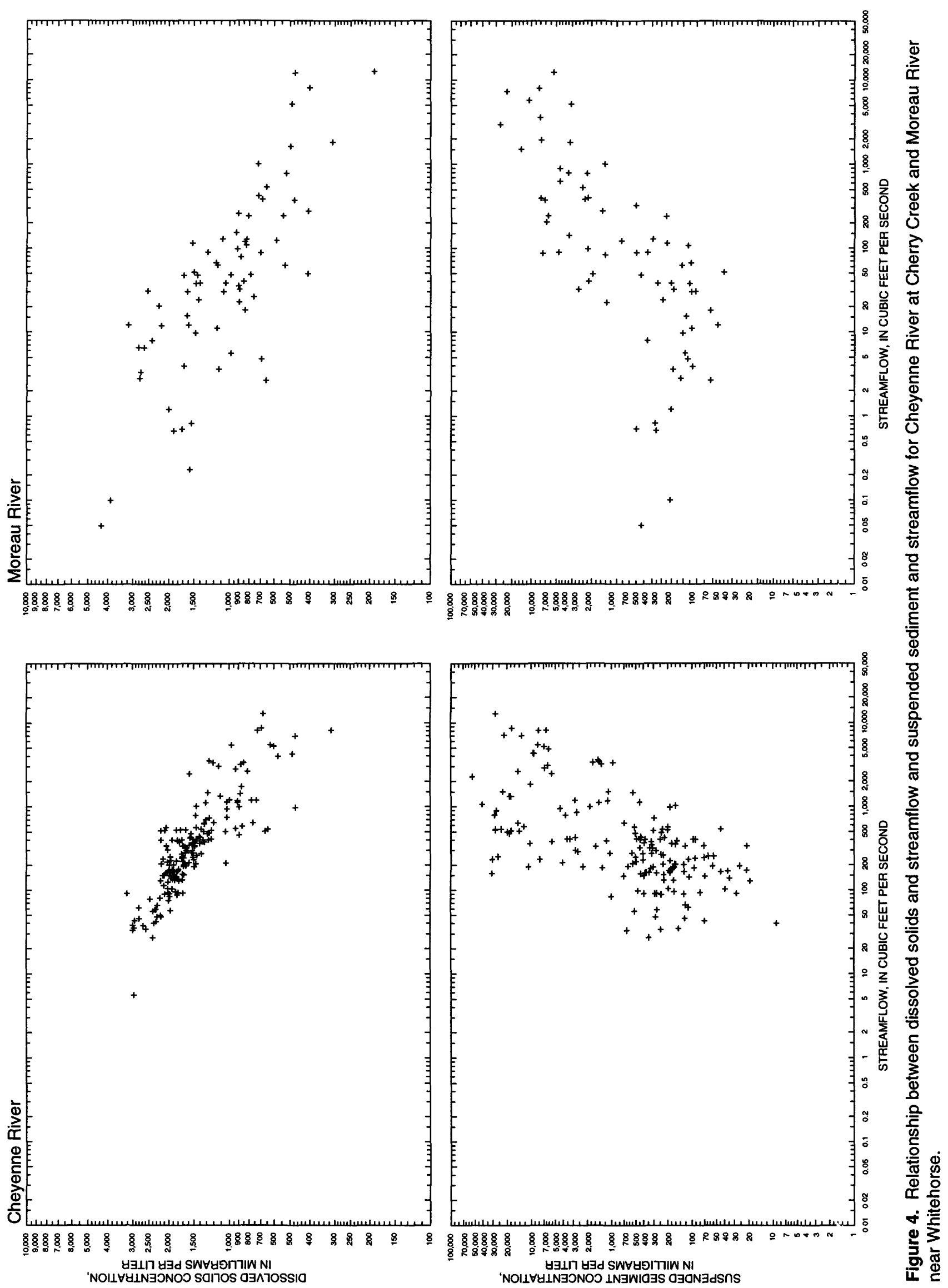


\section{Constituent Selection}

The two stations considered in this report have been operated for many years as part of the USGS National Stream-Quality Accounting Network (NASQAN) (Britton and others, 1983). More than 50 different water-quality constituents have been sampled at each site. Of these 50,14 constituents were selected for trend analysis. Except for total nitrogen, all the constituents selected for the trend analysis have standards, criteria, or recommended limits established by the State or the USEPA. A few constituents with established standards could not be analyzed for trend because of insufficient data. The 14 constituents selected for trend analysis were specific conductance, field $\mathrm{pH}$, fecal coliform bacteria, sodium-adsorption ratio, dissolved sulfate, dissolved chloride, dissolved solids, dissolved ammonia, total nitrogen, total phosphorus, dissolved arsenic, dissolved manganese, dissolved selenium, and suspended sediment. The water-quality criteria, standards, or recommended limits for selected constituents used to assess the water quality at the Cheyenne and Moreau River stations are summarized in table 1.

The results of previous water-quality investigations reported by universities and the USGS (U.S. Geological Survey, Office of Water Quality Technical Memorandum 91.10, Sept. 30, 1991) revealed sporadic contamination problems in reported concentrations of certain trace elements in water samples collected by the NASQAN program. The contamination was due to inadequacies in standard sampling and processing procedures used by the USGS nationwide. In 1993, the USGS changed sampling protocols and quality-control procedures to correct problems related to contamination during sampling and processing.

Because of documented sporadic contamination in USGS trace-element data, a thorough examination of NASQAN data collected by the USGS in South Dakota was performed to determine whether the variability in concentrations of dissolved arsenic was due to actual environmental variability or to sample contamination. The data analysis indicated that temporal trends in dissolved arsenic concentrations for the Cheyenne and Moreau River NASQAN stations were distinctively different from other South Dakota NASQAN stations during the same time periods (Steve Sando, U.S. Geological Survey, written commun., 1997). Although it is likely that some of the dissolved arsenic concentrations reported in this study may have been influenced by sample contamination, most arsenic values detected in environmental samples were in the range of 5 to $20 \mu \mathrm{g} / \mathrm{L}$, and it is unlikely that sample contamination could account for all the arsenic detected in the samples. Even if the arsenic data could be corrected for sample contamination, enough arsenic concentration data would exist above the detection limit in the environmental samples to perform a trend analysis. However, no corrections could be mad\%. Results of the arsenic data analysis support the conclusion that reported concentrations adequately represent actual environmental conditions. Therefore, no dissolved arsenic data were excluded from any of the analyses performed for this study based on uncertainties due to sample contamination.

Dissolved iron was not selected because an examination of the data showed that all South Dakota NASQAN stations have a similar decreasing trend in dissolved iron concentration over the period, from about 20 to $30 \mu \mathrm{g} / \mathrm{L}$ in 1980 to about $10 \mu \mathrm{g} / \mathrm{L}$ in 1995 (Steve Sando, U.S. Geological Survey, written commun., 1997). This decrease may be associated with changes made at the USGS National Water Quality Laboratory (NWQL) in Arvada, Colorado, in the analytical methods used to analyze samples for dissolved iron. Before 1980, the NWQL analyzed dissolved iron using flame atomic absorption spectrophotometry. Beginning in 1980, the NWQL began using the much more sensitive Inductively Coupled Argon Plasma (ICP) spectrophotometer to analyze dissolved iron. Analysis of quality assurance samples collected during 1980-94 in South Dakota indicate that dissolved iron is detected in about one-third to on:-half of blank samples collected, at concentrations of about 3 to $6 \mu \mathrm{g} / \mathrm{L}$. It therefore is likely that changing to a more sensitive analytical procedure and improvements in equipment cleaning and handling protocols may account for the decreasing trends in dissolved iron concentration at both sites.

Temporal trends in dissolved lead concentrations also were considered for the Cheyenne and Moraau River NASQAN stations. Unlike arsenic, the trends were not substantially different from those at otl or South Dakota NASQAN stations (Steve Sando, U.S. Geological Survey, written commun., 1997). Tre consistent patterns in temporal variability of dissolved lead concentrations at the various NASQAN stations probably indicate consistent sample contamination, in the very low micrograms per liter range, introdused during collection and processing of water samples at all of the NASQAN stations, and do not accurately represent changes in environmental conditions. Because the 


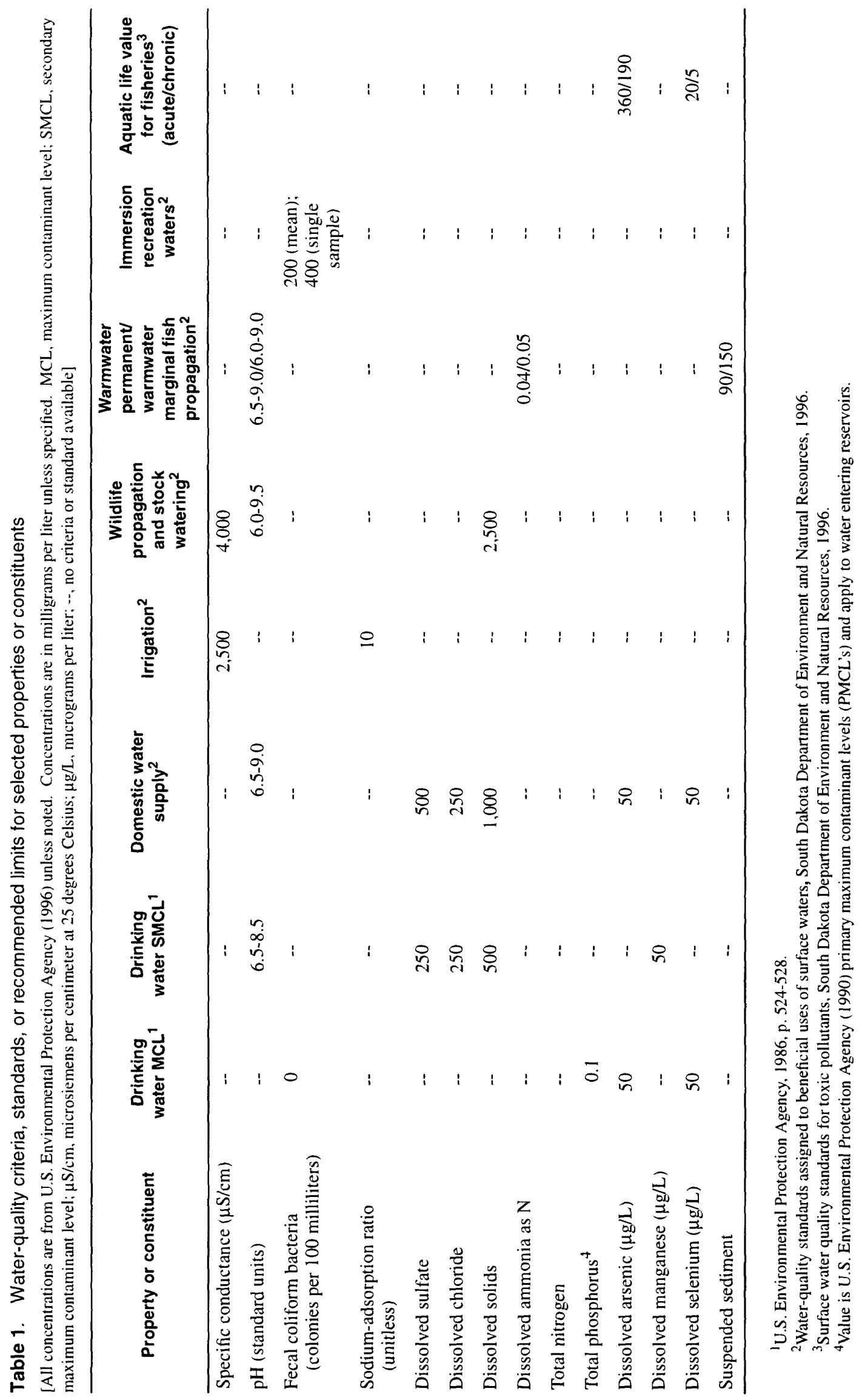


reported dissolved lead concentrations are typically very low (median values of 0.7 and $1.0 \mu \mathrm{g} / \mathrm{L}$ for the Cheyenne and Moreau Rivers, respectively), it is possible that sample contamination could account for most if not all of the lead detected in the samples. If the uncertainty introduced by contamination was accounted for, only lead concentration data at or below the reporting limit would remain for the environmental samples, and a trend analysis could not be performed. Therefore, dissolved lead data were excluded from all statistical distribution or trend analyses performed for this study.

Temporal trends in dissolved mercury also were considered at the Cheyenne and Moreau River NASQAN stations, and again, sample contamination problems were observed. Mercuric chloride was used as a preservative for nutrient samples collected by the USGS beginning in October 1980 (U.S. Geological Survey, Office of Water Quality Technical Memorandum 80.26 , Sept. 19, 1980). The use of mercuric chloride as a preservative is known to have contaminated water samples collected for dissolved mercury analysis (U.S. Geological Survey, Office of Water Quality Technical Memorandum 90.01, Oct. 3, 1989). Beginning in 1989, procedures were implemented to reduce contamination of trace-element samples resulting from the use of mercuric chloride. In October 1994, the USGS discontinued use of mercuric chloride as a preservative (U.S. Geological Survey, Office of Water Quality Technical Memorandum 94.16, Aug. 5, 1994). An examination of NASQAN data collected by the USGS in South Dakota indicated that during 1980 through 1990, sporadic contamination of water samples collected for dissolved mercury analysis was apparent (fig. 5). This is significant because dissolved mercury concentrations collected outside the period 1980 through 1990 generally were at or below the analytical detection limit and did not show a clear or consistent pattern of dissolved mercury contamination. Unlike arsenic, most mercury values detected in environmental samples were in the range of 0.2 to $0.5 \mu \mathrm{g} / \mathrm{L}$; it is possible that sample contamination accounted for most if not all of the mercury detected in the samples. If the uncertainty introduced by sample contamination could be accounted for, only mercury concentration data at or below the reporting limit might remain for the environmental samples and a trend analysis could not be performed. Therefore, dissolved mercury data were excluded from all statistical distribution or trend analyses performed for this study.
Specific conductance (conductivity) is a measure of the electrical conductance of a substance normalized to unit length and unit cross section at a specified temperature. Specific conductance of water is a function of the types and quantities of dissolved substances in water. As ion content increases in water, so does specific conductance. Therefore, pure water has a very low specific conductance. The USGS reports specific conductance in microsiemens per centimeter at 25 degrees Celsius. Specific conductance values also can be used to estimate the concentration of dissolved solids in water. The USEPA has not established a drinking-water standard for specific conductance. The State has established a standard of $2,500 \mu \mathrm{S} / \mathrm{cm}$ for irrigation and $4,000 \mu \mathrm{S} / \mathrm{cm}$ for water used for wildlife propagation and stock watering.

The negative log of the hydrogen ion activity $(\mathrm{pH})$, was selected as a constituent of concern because of the influence $\mathrm{pH}$ has on numerous dissolution reactions that are largely responsible for imparting chemical characteristics to water. Additionally, most biological systems function within a relatively narrow $\mathrm{pH}$ range. The USEPA has established that the secondary maximum contaminant level (SMCL) range should be between 6.5 to $8.5 \mathrm{pH}$ units for public water supplies (table 1). An SMCL is only a recommended level for a constituent and is considered nonenforceable by Federal guidelines outlined in the Safe Drinking Water Act of 1986, whereas a maximum contaminant level (MCL) established by the USEPA is enforceable. The State of South Dakota has established that the domestic water-supply criteria be between 6.5 to $9.0 \mathrm{pH}$ units.

Fecal coliform bacteria is a constituent of concern because it indicates water has been contaminated with animal feces. Potential sources of fecal coliform bacteria in surface waters are wild or domestic animals that use streams for drinking water, runoff from livestock impoundments, and effluent from sewage treatment facilities. The USEPA has established an MCL of $0 \mathrm{col} / 100 \mathrm{~mL}$ for public drinkingwater supplies. The State surface-water-quality standard states that coliform organisms may not exceed an MPN (most probable number) or MF (membrane filtration) of $5,000 \mathrm{col} / 100 \mathrm{~mL}$ as a geometric mean based on a minimum of five samples obtained during separate 24-hour periods for a 30-day period; may not exceed this value in more than 20 percent of the samples examined in the above described 30-day period; and may not exceed $20,000 \mathrm{col} / 100 \mathrm{~mL}$ in any one sample 


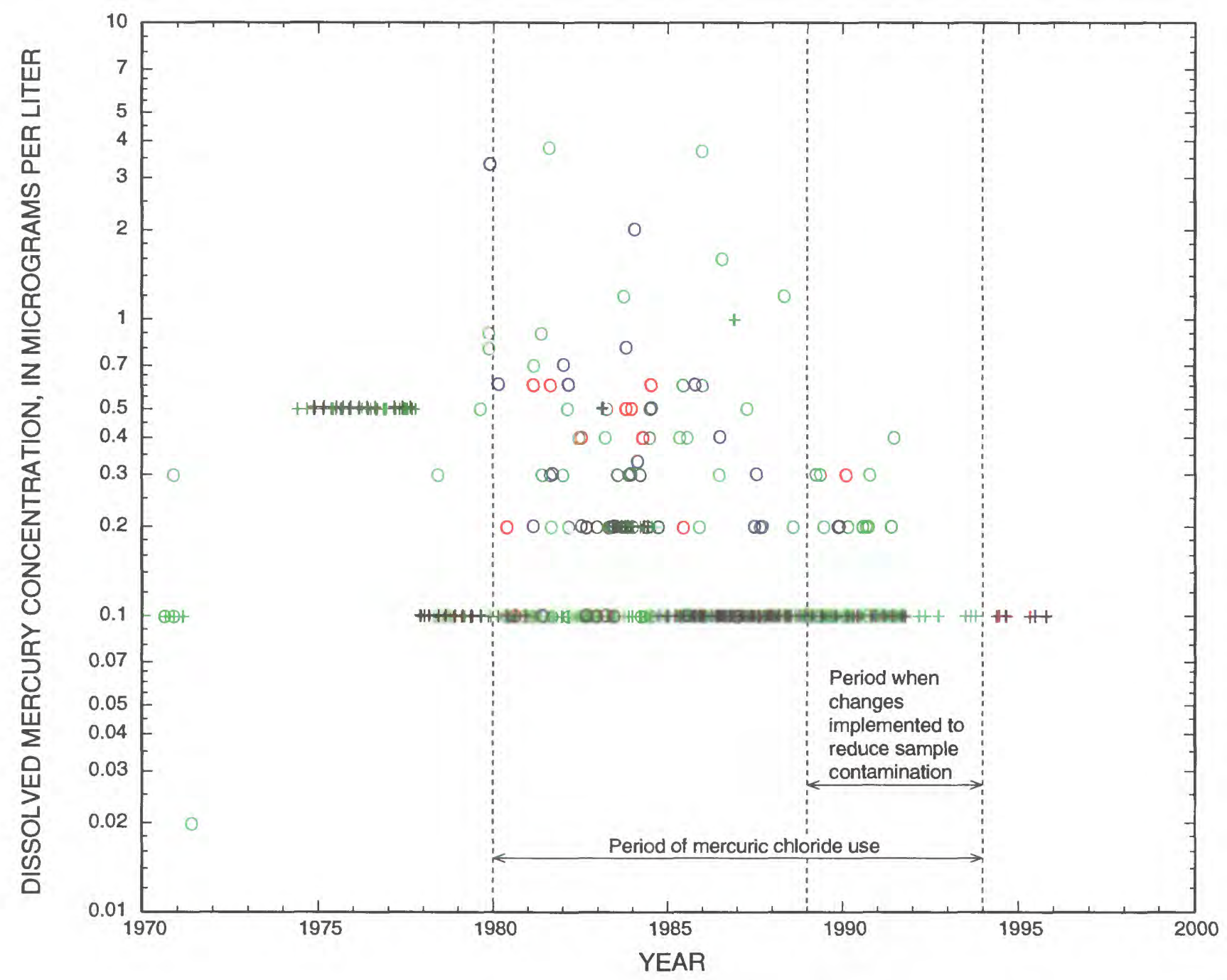

\section{EXPLANATION}

O CHEYENNE RIVER AT CHERRY CHREEK

+ CHEYENNE RIVER AT CHERRY CREEK--Censored values plotted at reporting limit

O MOREAU RIVER NEAR WHITEHORSE

+ MOREAU RIVER NEAR WHITEHORSE--Censored values plotted at reporting limit

- ALL OTHER SOUTH DAKOTA NASQAN STATIONS

+ ALL OTHER SOUTH DAKOTA NASQAN STATIONS--Censored values plotted at reporting limit

Figure 5. Dissolved mercury concentrations for Cheyenne River at Cherry Creek, Moreau River near Whitehorse, and all other South Dakota NASQAN stations. 
(South Dakota Department of Environment and Natural Resources, 1996). The State standard for immersion recreation water is $200 \mathrm{col} / 100 \mathrm{~mL}$ (mean) or $400 \mathrm{col} / 100 \mathrm{~mL}$ (single sample).

Sodium-adsorption ratio (SAR) is a value which may be used to predict the degree to which sodium in irrigation water will replace adsorbed calcium and magnesium in soil. When irrigation waters with high SAR values are applied, they have the potential to harm both plants and soil. The State has established an SAR value of 10 for irrigation waters.

High concentrations of sulfate in drinking water can have a laxative effect. Sulfate can be added to water through the oxidation of organic materials. Sulfate also can be produced by the bacterial oxidation of reduced sulphur compounds (Wetzel and Likens, 1979). Weathering of certain rock types, mine drainage wastes, and burning of high sulphur coal also can contribute sulfate to surface waters. The USEPA has established an SMCL of $250 \mathrm{mg} / \mathrm{L}$ for sulfate in public water supplies. The State has established a surfacewater-quality standard of $500 \mathrm{mg} / \mathrm{L}$ for domestic water-supply sources.

Chloride typically is present naturally in all fresh water at relatively low concentrations (Hem, 1985). Elevated chloride concentrations in surface water can result from numerous anthropogenic and natural sources. High concentrations of chloride can be harmful to humans, plants, and animals. The USEPA has established an SMCL for chloride in drinking water at $250 \mathrm{mg} / \mathrm{L}$. The State criteria for chloride in domestic water supplies also is $250 \mathrm{mg} / \mathrm{L}$.

Water with high concentrations of dissolved solids can have objectionable tastes or cause adverse physiological effects when consumed by humans and livestock. Dissolved solids result from the dissolution of rock in contact with water. Water containing high concentrations of dissolved solids can be corrosive and may require additional treatment. Highly mineralized water may have unfavorable effects on pumps and plumbing fixtures and adversely affect aquatic organisms. The USEPA has established an SMCL of $500 \mathrm{mg} / \mathrm{L}$ for dissolved solids in public water supplies. The State has established standards of $1,000 \mathrm{mg} / \mathrm{L}$ for domestic water-supply sources, and $2,500 \mathrm{mg} / \mathrm{L}$ for wildlife propagation and stock watering.

Inorganic nitrogen compounds such as ammonia $\left(\mathrm{NH}_{3}\right)$ are usually present naturally in fresh water at concentrations less than $1 \mathrm{mg} / \mathrm{L}$. They typically form from the decomposition of animal and plant proteins.
With low concentrations of dissolved oxygen, as in polluted waters, reduced nitrogen compounds (such as ammonia) can increase dramatically. Ammonia is a plant nutrient that can cause unwanted algal blooms and excessive plant growth when present at elevated levels in water bodies. Sources of ammonia incl ide agricultural and urban runoff and effluent from wastewater treatment plants. Neither the USEPA nor the State have established drinking-water standards for ammonia. The State has set the ammonia standa-d for warmwater permanent fish propagation at $0.04 \mathrm{mg} / \mathrm{L}$, and warmwater marginal fish propagation standard at $0.05 \mathrm{mg} / \mathrm{L}$.

Nitrogen is essential to all ecosystems beca'ise of its role in the synthesis and maintenance of protein, and therefore is very important in determining the productivity of an aquatic community. Derived originally from the atmosphere, nitrogen enters into a complex cycle involving plants and animals and occurs in several forms. Nitrogen compounds in natural waters can result from abiotic and biotic activities such as bacteria or algae within the body of water. Precipitation falling upon the land surface can carry nitrogen compounds (such as nitrate and ammonia), via surface runoff, into streams and lakes. Nonpoint sources of nitrogen include urban runoff, animal wastes, and agricultural chemicals. Neither the USEPA nor the : tate have established standards for total nitrogen.

Phosphorus is a nutrient for aquatic biota and a major cause of eutrophication in lakes (Hem, 1985). It is an extremely important element for maintainirg. biogeochemical cycles and is required for energy' transfer in cells. Phosphorus typically is present at low concentrations in unpolluted streams, but in sufficient quantities it can cause agal blooms and excessive plant growth. Phosphorus is present in some insecticides and fertilizers and can sometimes be traced to surface water through agricultural return flows. Phosphorus is present in sewage and may be found in surface water as a result of discharges of treated sewage effluents. leaking septic systems, and in runoff from livestock impoundments. The USEPA (1990) has established an MCL of $0.10 \mathrm{mg} / \mathrm{L}$ for phosphorus in streams that flow into reservoirs. The State does not have a surfacewater-quality standard for phosphorus.

Arsenic is a known carcinogen to humans (Lucius and others, 1992). Arsenic can be acutely toxic to humans and animals in large quantities, or chronically toxic in small quantities, because of the ability of arsenic to bioaccumulate within tissues. Acute toxicity 
refers to the ability of a substance to cause adverse health effects or death from a single short-term exposure. Chronic toxicity refers to the ability of a substance to cause long-term adverse health effects. In aqueous solution, arsenic can exist as $\mathrm{As}^{+3}$ (arsenite) or $\mathrm{As}^{+5}$ (arsenate), depending on reduction-oxidation conditions. Arsenite is more toxic than arsenate (U.S. Environmental Protection Agency, 1986), but either species may be harmful at elevated concentrations (Roberts and others, 1985). The USEPA has established an MCL for arsenic of $50 \mu \mathrm{g} / \mathrm{L}$ for sources of public drinking-water supply. The State also has established a water-quality standard for arsenic of $50 \mu \mathrm{g} / \mathrm{L}$ for sources of public drinking-water supply.

Manganese occurs naturally in various rocks and is essential for plant growth and development. Elevated concentrations of manganese in water supplies have a tendency to deposit undesirable black oxide stains (Hem, 1985). The USEPA has established an SMCL of $50 \mu \mathrm{g} / \mathrm{L}$ for manganese for sources of public drinking-water supplies. The State does not have a surface-water-quality standard for manganese.

Most of the selenium entering the aquatic environment comes from the weathering of selenium-rich sedimentary rocks or the erosion of seleniferous soils. Elemental selenium is considered to be relatively nonirritating and is poorly absorbed, although other selenium species can be extremely toxic. There is evidence that selenium is an essential trace element for man, but may be toxic above some concentration. Selenium is harmful to many aquatic organisms, and the State has established an aquatic life value for fisheries of $20 \mu \mathrm{g} / \mathrm{L}$ (acute) and $5.0 \mu \mathrm{g} / \mathrm{L}$ (chronic). The USEPA has established an MCL for selenium of $50 \mu \mathrm{g} / \mathrm{L}$ for sources of public drinking-water supplies. The State has proposed a surface-water-quality standard for selenium of $10 \mu \mathrm{g} / \mathrm{L}$ for sources of public drinking-water supply.

Suspended sediments typically result from rock erosion. Concentrations of suspended sediment generally are proportional to streamflow, or velocity (fig. 4). Human activities that disturb land cover such as mining, logging, farming, and construction have the potential to increase the availability of solid materials for transport. Suspended sediments can harm aquatic organisms and decrease reservoir capacity but also can provide food sources for bacteria. Suspended sediments also provide sorption sites for the transport of organic and inorganic constituents. Neither the USEPA nor the State have established drinking-water standards for suspended sediment. The State has set the standard for suspended sediment for warmwater permanent fish propagation at $90 \mathrm{mg} / \mathrm{L}$, and warmwater marginal fish propagation standard at $150 \mathrm{mg} / \mathrm{L}$.

\section{GENERAL DESCRIPTION OF V'ATER QUALITY}

Long-term water-quality data are available for stations 06439300, Cheyenne River at Cherry Creek, and 06360500, Moreau River near Whitehorse. Waterquality samples have been collected at $k$ th sites since 1972, as part of the USGS NASQAN program (Britton and others, 1983). Summary statistics of water-quality data for the period of record are presented in table 2 for the Cheyenne River station, and in table 3 for the Moreau River station.

Boxplots are used to visually display the data distribution for each selected constituent and are shown in figures 6-19 in the Supplemental Information section at the end of this report. The boxplots are constructed by ranking the data in order from the smallest to the largest concentration, and plotting selected percentiles. For example, the 75 th percentile, also called the upper quartile, is a value which exceeds no more than 75 percent of the data and is exceeded by no more than 25 percent of the data. The 25 th percentile, or lower quartile, is a value which exceeds no more than 25 percent of the data and is exceeded by no more than 75 percent of the data (Helsel and Hirsch, 1992). A box is then constructed from the 25th prontile to the 75 th percentile. The length of the box is defined as the interquartile range. A line is then drawn horizontally across the box at the median value. Heights of the box sections created by the median line represent the quartile skew. Vertical lines called whiskers, which represent adjacent values, are drawn down from the 25th percentile and up from the 75th percentile. The upper adjacent value is defined as the largest data point that is less than or equal to the upper quartile plus 1.5 times the interquartile range. The lower adjarent value is defined as the smallest data point that is greater than or equal to the lower quartile minus 1.5 times the interquartile range. A log-probability regression method (Helsel and Gilliom, 1985) is used to estimate median and percentile values for boxplots of trace elements because it improves estimates of distributional parameters when data that are less than reporting limits are present. 
Table 2. Summary statistics for water-quality data used to develop boxplots for station 06439300 , Cheyenne River at Cherry Creek

[Values are in milligrams per liter unless otherwise indicated. $\mu \mathrm{S} / \mathrm{cm}$, microsiemens per centimeter at 25 degrees Celsius; col $100 \mathrm{~mL}$, colonies per 100 milliliters: $\mu \mathrm{g} / \mathrm{L}$, micrograms per liter; <, less than analytical reporting limit; --, not calculated]

\begin{tabular}{|c|c|c|c|c|c|c|c|c|}
\hline $\begin{array}{l}\text { Property or } \\
\text { constituent }\end{array}$ & $\begin{array}{l}\text { Period } \\
\text { of } \\
\text { record }\end{array}$ & $\begin{array}{c}\text { Number } \\
\text { of } \\
\text { samples }\end{array}$ & Mean & Median & Minimum & Maximum & $\begin{array}{l}\text { Standard } \\
\text { deviation }\end{array}$ & $\begin{array}{l}\text { Stardard } \\
\text { errior of } \\
\text { the mean }\end{array}$ \\
\hline $\begin{array}{l}\text { Specific conductance } \\
(\mu \mathrm{S} / \mathrm{cm})\end{array}$ & $06 / 72-07 / 94$ & 269 & 2,085 & 2,145 & 610 & 3,900 & 594 & 36.2 \\
\hline $\mathrm{pH}$ (standard units) & $06 / 72-06 / 94$ & 228 & -- & 8.2 & 7.2 & 9.2 & -- & -- \\
\hline $\begin{array}{l}\text { Fecal coliform bacteria } \\
\quad(\mathrm{col} / / 100 \mathrm{~mL})\end{array}$ & $10 / 76-07 / 94$ & 108 & 266 & 30.0 & $<1.0$ & 8,400 & 961 & 92.5 \\
\hline $\begin{array}{l}\text { Sodium-adsorption ratio } \\
\text { (unitless) }\end{array}$ & $06 / 72-08 / 94$ & 197 & 3.27 & 3.10 & 1.46 & 15.2 & 1.47 & 0.1 \\
\hline Dissolved sulfate & $06 / 72-07 / 94$ & 200 & 991 & 1,025 & 140 & 1,900 & 334 & 23.6 \\
\hline Dissolved chloride & $06 / 72-07 / 94$ & 198 & 57.7 & 54.0 & 3.10 & 240 & 35.3 & 2.51 \\
\hline Dissolved solids & $06 / 72-07 / 94$ & 195 & 1,636 & 1,686 & 310 & 3,182 & 542 & $7 ? .8$ \\
\hline Dissolved ammonia as $\mathrm{N}$ & $08 / 72-08 / 94$ & 77 & 0.11 & 0.07 & 0.0 & 0.99 & 0.14 & 0.02 \\
\hline Total nitrogen & $08 / 72-08 / 92$ & 154 & 0.94 & 0.51 & 0.0 & 5.8 & 1.1 & 0.08 \\
\hline Total phosphorus & $06 / 72-07 / 94$ & 178 & 0.79 & 0.16 & 0.005 & 18.0 & 2.26 & 0.17 \\
\hline Dissolved arsenic $(\mu \mathrm{g} / \mathrm{L})$ & $10 / 74-07 / 94$ & 113 & 6.2 & 4.0 & 1.0 & 26.0 & 5.5 & 0.53 \\
\hline $\begin{array}{l}\text { Dissolved manganese } \\
(\mu \mathrm{g} / \mathrm{L})\end{array}$ & $06 / 72-07 / 94$ & 128 & 41.6 & 20.0 & 0.2 & 460 & 65.1 & 5.7 \\
\hline $\begin{array}{l}\text { Dissolved selenium } \\
(\mu \mathrm{g} / \mathrm{L})\end{array}$ & $10 / 74-07 / 94$ & 100 & 3.4 & 3.0 & 1.0 & 15.0 & 2.4 & 0.24 \\
\hline Suspended sediment & 07/72-07/94 & 166 & 4,562 & 393 & 9.0 & 53,900 & 8,885 & 697 \\
\hline
\end{tabular}

Median values for specific conductance were 2,145 and $1,410 \mu \mathrm{S} / \mathrm{cm}$ for stations 06439300 , Cheyenne River at Cherry Creek (table 2), and 06360500, Moreau River near Whitehorse (table 3), respectively. A maximum value of $3,900 \mu \mathrm{S} / \mathrm{cm}$ was recorded for the Cheyenne River station. A maximum value of $4,700 \mu \mathrm{S} / \mathrm{cm}$ was recorded for the Moreau River station.

The median $\mathrm{pH}$ values for both the Cheyenne and Moreau River stations were 8.2 and were within the acceptable range promulgated by the USEPA of 6.5 to 8.5 and the State of 6.5 to 9.0 for sources of public drinking-water supply. The maximum value of 9.2 for the Cheyenne River station exceeds the drinking-water SMCL and the State standard for domestic water supply, as well as the warmwater permanent and warmwater marginal fish propagation standard. A maximum value of 8.9 was recorded for the Moreau River station. This value exceeds the SMCL for domestic water supply.
Median values for fecal coliform bacteria concentration were 30 and $45 \mathrm{col} / 100 \mathrm{~mL}$ for the Cheyenne and Moreau River stations, respectively. The maximum value of $8,400 \mathrm{col} / 100 \mathrm{~mL}$ recorded at the Cheyenne River station exceeded the immersion recreation standard. The USEPA MCL for total coliform is for treated drinking water and is not applicable to raw water. The maximum value of $15,900 \mathrm{col} / 100 \mathrm{~mL}$ recorded for the Moreau $\mathrm{Ri}$ /er station also exceeded the immersion recreation standard.

Median values for SAR were 3.1 and 6.4 for the Cheyenne and Moreau River stations, respectively. The maximum SAR values of 15.2 and 21.2 recorded for the Cheyenne and Moreau Rivers, respectively, both exceed the irrigation standard.

Median values for dissolved sulfate were 1,025 and $550 \mathrm{mg} / \mathrm{L}$ for the Cheyenne and Moreau River stations, respectively. Both of these values exceed the SMCL drinking-water standard of $250 \mathrm{mg} / \mathrm{L}$ promulgated by the USEPA and the criteria for domestic water 
Table 3. Summary statistics for water-quality data used to develop boxplots for station 06360500 , Moreau Fiver near Whitehorse

[Values are in milligrams per liter unless otherwise indicated. $\mu \mathrm{S} / \mathrm{cm}$, microsiemens per centimeter at 25 degrees Celsius; col/100 mL, colonies per 100 milliliters; $\mu \mathrm{g} / \mathrm{L}$, micrograms per liter; $<$, less than analytical reportıng limit; --, not calculated]

\begin{tabular}{|c|c|c|c|c|c|c|c|c|}
\hline $\begin{array}{l}\text { Property or } \\
\text { constituent }\end{array}$ & $\begin{array}{l}\text { Period } \\
\text { of } \\
\text { record }\end{array}$ & $\begin{array}{c}\text { Number } \\
\text { of } \\
\text { samples }\end{array}$ & Mean & Median & Minimum & Maximum & $\begin{array}{l}\text { Standard } \\
\text { deviation }\end{array}$ & $\begin{array}{l}\text { Standard } \\
\text { error of } \\
\text { the mean }\end{array}$ \\
\hline $\begin{array}{l}\text { Specific conductance } \\
(\mu \mathrm{S} / \mathrm{cm})\end{array}$ & $11 / 77-07 / 94$ & 118 & 1,684 & 1,410 & 322 & 4,700 & 931 & 85.4 \\
\hline $\mathrm{pH}$ (standard units) & $11 / 77-07 / 94$ & 71 & -- & 8.2 & 7.4 & 8.9 & -- & -- \\
\hline $\begin{array}{l}\text { Fecal coliform bacteria } \\
(\mathrm{col} / 100 \mathrm{~mL})\end{array}$ & $11 / 77-05 / 94$ & 71 & 648 & 45.0 & 2.0 & 15,900 & 2,367 & 281 \\
\hline $\begin{array}{l}\text { Sodium-adsorption ratio } \\
\text { (unitless) }\end{array}$ & $11 / 77-07 / 94$ & 75 & 7.6 & 6.4 & 1.9 & 21.2 & 3.7 & 0.4 \\
\hline Dissolved sulfate & $11 / 77-07 / 94$ & 75 & 711 & 550 & 87 & 2,300 & 495 & 57.2 \\
\hline Dissolved chloride & $11 / 77-07 / 94$ & 75 & 14.6 & 9.9 & 0.9 & 91.0 & 14.3 & 1.6 \\
\hline Dissolved solids & $12 / 77-06 / 94$ & 74 & 1,266 & 983 & 191 & 4,305 & 826 & 96 \\
\hline Dissolved ammonia as $\mathrm{N}$ & $12 / 79-06 / 94$ & 58 & 0.06 & 0.05 & 0.0 & 0.38 & $0.0^{\prime}$ & 0.01 \\
\hline Total nitrogen & $03 / 78-06 / 94$ & 72 & 0.3 & 0.1 & 0.0 & 2.8 & 0.41 & 0.05 \\
\hline Total phosphorus & $11 / 77-07 / 94$ & 75 & 0.44 & 0.09 & 0.02 & 3.8 & 0.81 & 0.09 \\
\hline Dissolved arsenic $(\mu \mathrm{g} / \mathrm{L})$ & $11 / 77-07 / 94$ & 43 & 1.6 & 1.0 & $<1.0$ & 7.0 & 1.1 & 0.18 \\
\hline $\begin{array}{l}\text { Dissolved manganese } \\
\quad(\mu \mathrm{g} / \mathrm{L})\end{array}$ & $11 / 77-07 / 94$ & 49 & 20.9 & 8.0 & 0.2 & 140 & 29.9 & 4.28 \\
\hline $\begin{array}{l}\text { Dissolved selenium } \\
\quad(\mu \mathrm{g} / \mathrm{L})\end{array}$ & $11 / 77-07 / 94$ & 48 & 1.9 & 1.0 & 0.5 & 5.0 & 1.1 & 0.16 \\
\hline Suspended sediment & $07 / 72-07 / 94$ & 70 & 2,686 & 488 & 40 & 24,500 & 4,483 & 536 \\
\hline
\end{tabular}

supply of $500 \mathrm{mg} / \mathrm{L}$ set by the State. A maximum value of $1,900 \mathrm{mg} / \mathrm{L}$ was recorded for the Cheyenne River station. A maximum value of $2,300 \mathrm{mg} / \mathrm{L}$ was recorded for the Moreau River station.

Median values for dissolved chloride were 54.0 and $9.9 \mathrm{mg} / \mathrm{L}$ for the Cheyenne and Moreau River stations, respectively. A maximum value of $240 \mathrm{mg} / \mathrm{L}$ was recorded for the Cheyenne River station. A maximum value of $91.0 \mathrm{mg} / \mathrm{L}$ was recorded for the Moreau River station.

Median values for dissolved solids were 1,686 and $983 \mathrm{mg} / \mathrm{L}$ for the Cheyenne and Moreau River stations, respectively. Both of these values exceeded the SMCL, and the Cheyenne River value exceeds the State criteria. A maximum value of $3,182 \mathrm{mg} / \mathrm{L}$ was recorded for the Cheyenne River station. A maximum value of 4,305 $\mathrm{mg} / \mathrm{L}$ was recorded for the Moreau River station. Maximum values for both stations exceed standards for wildlife propagation and stock watering.
Median values for dissolved ammonia were 0.07 and $0.05 \mathrm{mg} / \mathrm{L}$ for the Cheyenne and Moreau River stations, respectively. The median values, as well as the maximum values of 0.99 and $0.38 \mathrm{mg} / \mathrm{L}$ recorded for the Cheyenne and Moreau River stations, respectively, meet or exceed the State standards of 0.04 and $0.05 \mathrm{mg} / \mathrm{L}$ for permanent and marginal warmwater fish propagation (table 1 ).

Median values for total nitrogen were 0.51 and $0.1 \mathrm{mg} / \mathrm{L}$ for the Cheyenne and Moreau River stations, respectively. Maximum values of 5.8 and $2.8 \mathrm{mg} / \mathrm{L}$ were recorded for the Cheyenne and Moreau River stations, respectively.

Median values for total phosphorus were 0.16 and $0.09 \mathrm{mg} / \mathrm{L}$ for the Cheyenne and Moreau River stations, respectively. A maximum value of $18.0 \mathrm{mg} / \mathrm{L}$ was recorded for the Cheyenne River station. A maximum value of $3.8 \mathrm{mg} / \mathrm{L}$ was recorded for the Moreau River station.

Median values for dissolved arsenic were 4.0 and $1.0 \mu \mathrm{g} / \mathrm{L}$ for the Cheyenne and Moreau River 
stations, respectively. A maximum value of $26.0 \mu \mathrm{g} / \mathrm{L}$ was recorded for the Cheyenne River station. A maximum value of $7.0 \mu \mathrm{g} / \mathrm{L}$ was recorded for the Moreau River station.

Median values for dissolved manganese were 20.0 and $8.0 \mu \mathrm{g} / \mathrm{L}$ for the Cheyenne and Moreau River stations, respectively. A maximum value of $460 \mu \mathrm{g} / \mathrm{L}$ was recorded for the Cheyenne River station. A maximum value of $140 \mu \mathrm{g} / \mathrm{L}$ was recorded for the Moreau River station.

Median values for dissolved selenium were 3.0 and $1.0 \mu \mathrm{g} / \mathrm{L}$ for the Cheyenne and Moreau River stations, respectively. A maximum value of $15.0 \mu \mathrm{g} / \mathrm{L}$ was recorded for the Cheyenne River station. A maximum value of $5.0 \mu \mathrm{g} / \mathrm{L}$ was recorded for the Moreau River station. Maximum values for both stations equal or exceed chronic aquatic life values for fisheries.

Median values for suspended sediment were 393 and $488 \mathrm{mg} / \mathrm{L}$ for the Cheyenne and Moreau River stations, respectively. Median values at both stations exceed standards for both warmwater permanent and warmwater marginal fish propagation. A maximum value of $53,900 \mathrm{mg} / \mathrm{L}$ was recorded for the Cheyenne River station. A maximum value of $24,500 \mathrm{mg} / \mathrm{L}$ was recorded for the Moreau River station.

Water-quality data are compared to standards and criteria promulgated by both the USEPA and the SDDENR in tables 4 and 5. Comparisons are made to determine the number of times the selected constituents exceeded standards established to support the assigned beneficial uses for the Cheyenne and Moreau Rivers. Water-quality data also are compared to drinking-water standards that are not assigned as beneficial uses of surface waters for the two rivers. The comparisons are made to assess general water-quality conditions for each river at the respective sampling station.

\section{RESULTS OF TREND ANALYSIS}

Water-quality concentration data for 14 constituents collected at two stations were analyzed using either the Seasonal Kendall test for raw concentration data (RCD) or flow-adjusted concentration (FAC) data or the Tobit test for RCD to determine if trends existed. Unadjusted constituent concentration data were plotted against time and a trend line was calculated using either the Seasonal Kendall or Tobit test. The trend test that provided the most statistically significant $p$-value was selected. Whenever possible, the results of the Seasonal Kendall test on FAC data were used to define trends. Use of FAC data results in a more powerf $x 1$ test and therefore is preferred over use of RCD when attempting to accurately define trends in environrental conditions.

The results of the two trend methods for exch constituent are compared in tables 6 and 7 for the two stations. Analysis of data for dissolved iron, lead, and mercury indicate that these data sets may be biased and therefore statistical distributions and trend analyses were not performed for these constituents. Summary statistics used for the analysis of trends at the two stations are presented in tables 8 and 9. Raw data and trends are displayed graphically in figures. 20-33 in the Supplemental Information section. The LOWErS method (Locally Weighted Scatterplot Smoothing; Cleveland, 1979) is used to create the trend line that depicts changes in constituent concentration ove" time (figs. 20-33). This method provides more information than a linear fit of the data, because LOWESS can depict slight changes in trend that may have occ'urred within a relatively small portion of the entire time interval examined. LOWESS trend lines are not presented for constituents for which no trend is indicated.

Five constituents had trends that were statistically significant for the Cheyenne River. One constituent had a trend that was statistically significant for the Moreau River.

Trend analysis, based on the Seasonal Kendall test, of dissolved sulfate concentration for the Cheyenne River at Cherry Creek showed an increasing trend of 1.27 percent of the median per year, or $12.7 \mathrm{mg} / \mathrm{L}$ per year for RCD. The FAC data showed an increasing trend of 0.70 percent of the median per year, or $7.0 \mathrm{mg} / \mathrm{L}$ per year. McKallip (1993) also examined trends in dissolved sulfate at the same station for the 10-year period between 1980-89. He also found a statistically significant increasing trend in dissol'ed sulfate, with median concentrations exceeding State standards for some uses.

Dissolved chloride concentration data for the Cheyenne River at Cherry Creek showed increasing trends for both the RCD and FAC data. The RCD was increasing at 1.87 percent of the median per year, or $1.0 \mathrm{mg} / \mathrm{L}$ per year, and the FAC data was increasing at 1.43 percent of the median per year, or $0.76 \mathrm{mg} / \mathrm{L}$ per year. 


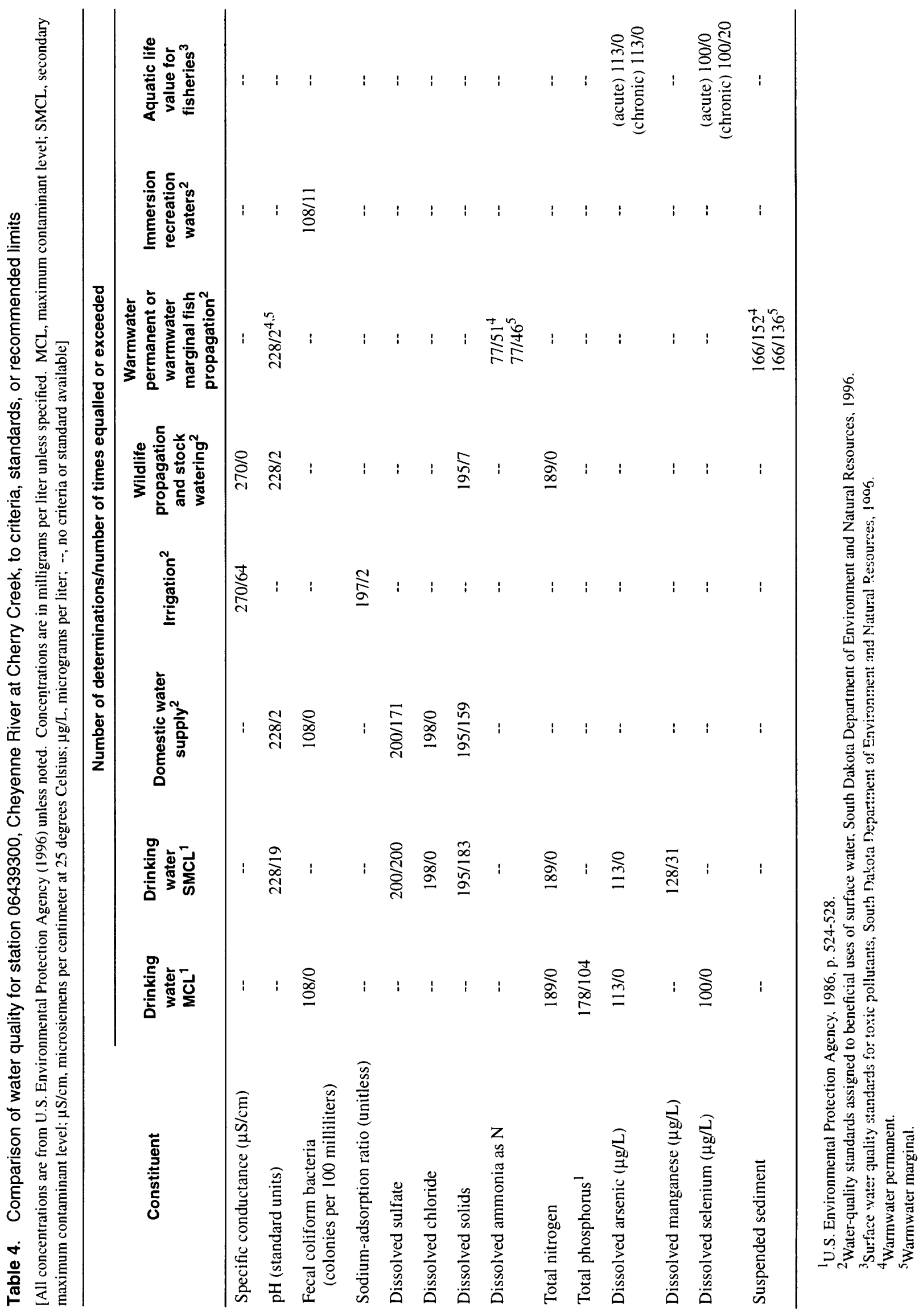




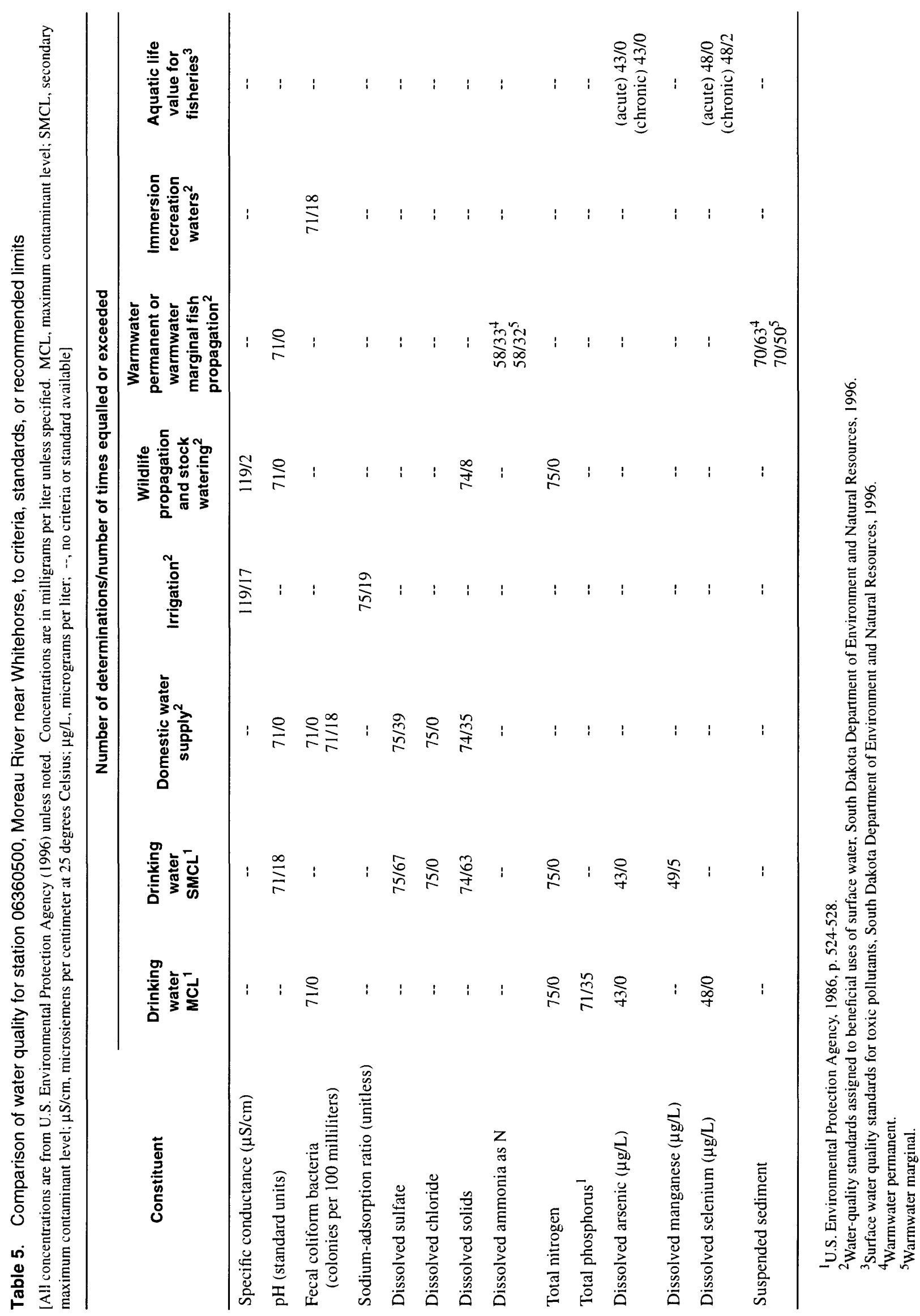


Table 6. Results of Seasonal Kendall and Tobit test for trend on water-quality data for Cheyenne River at Crerry Creek [Numbers in bold were used to assess trend magnitude and significance. Trend is in milligrams per liter per year unless otherwise indicated. $\mu \mathrm{S} / \mathrm{cm}$, microsiemens per centimeter at 25 degrees Celsius; col/100 mL, colonies per 100 milliliters; $\mu \mathrm{g} / \mathrm{L}$, micrograms per liter; <, less than; NT, no trend; --, no results]

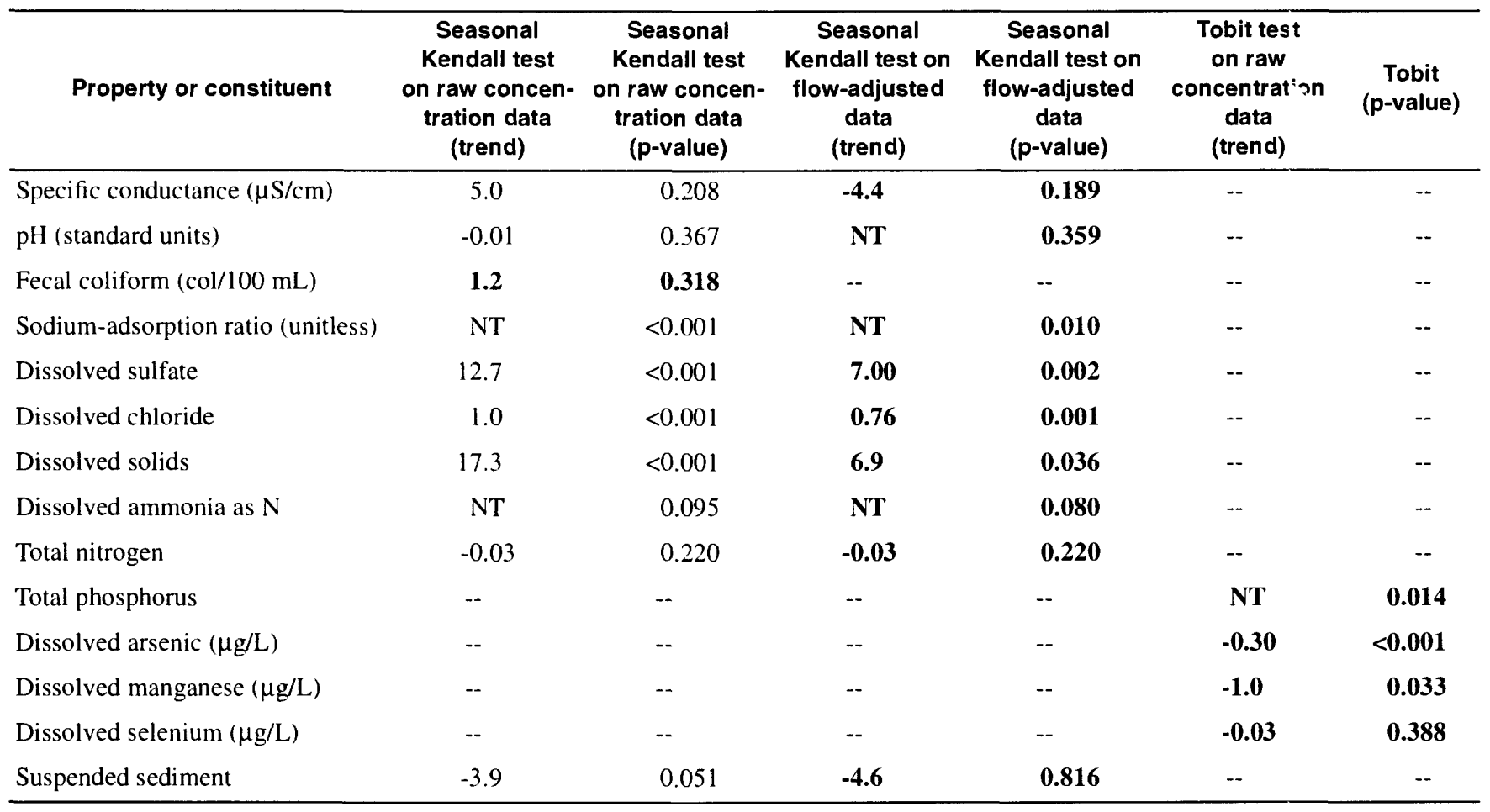

Table 7. Results of Seasonal Kendall and Tobit test for trend on water-quality data for Moreau River near W/-itehorse [Numbers in bold were used to assess trend magnitude and significance. Trend is in milligrams per liter per year unless otherwise indicited. $\mu \mathrm{S} / \mathrm{cm}$, microsiemens per centimeter at 25 degrees Celsius; col/100 mL. colonies per 100 milliliters; $\mu \mathrm{g} / \mathrm{L}$, micrograms per liter; NT, no trend; --, no results]

\begin{tabular}{|c|c|c|c|c|c|c|}
\hline Property or constituent & $\begin{array}{c}\text { Seasonal } \\
\text { Kendall test } \\
\text { on raw concen- } \\
\text { tration data } \\
\text { (trend) }\end{array}$ & $\begin{array}{c}\text { Seasonal } \\
\text { Kendall test } \\
\text { on raw concen- } \\
\text { tration data } \\
\text { (p-value) }\end{array}$ & $\begin{array}{c}\text { Seasonal } \\
\text { Kendall test on } \\
\text { flow-adjusted } \\
\text { data } \\
\text { (trend) }\end{array}$ & $\begin{array}{c}\text { Seasonal } \\
\text { Kendall test on } \\
\text { flow-adjusted } \\
\text { data } \\
\text { (p-value) }\end{array}$ & $\begin{array}{c}\text { Tobit test } \\
\text { on raw } \\
\text { concentration } \\
\text { data } \\
\text { (trend) }\end{array}$ & $\begin{array}{c}\text { Tobit } \\
\text { (p-value) }\end{array}$ \\
\hline Specific conductance $(\mu \mathrm{S} / \mathrm{cm})$ & 4.6 & 0.681 & 4.6 & 0.411 & - & - \\
\hline $\mathrm{pH}$ (standard units) & 0.02 & 0.038 & 0.02 & $\mathbf{0 . 0 5 7}$ & -- & -- \\
\hline Sodium-adsorption ratio (unitless) & NT & 0.934 & -0.1 & 0.155 & -- & -- \\
\hline Dissolved sulfate & 1.2 & 0.716 & -2.5 & 0.559 & -- & -- \\
\hline Dissolved chloride & NT & 0.935 & 0.09 & 0.253 & -- & -- \\
\hline Dissolved solids & 0.5 & 0.921 & 15.3 & 0.264 & -- & -- \\
\hline Dissolved arsenic $(\mu \mathrm{g} / \mathrm{L})$ & -0.04 & 0.43 & -- & -- & -- & -- \\
\hline Dissolved manganese $(\mu \mathrm{g} / \mathrm{L})$ & -- & -- & -- & -- & -0.1 & 0.001 \\
\hline Dissolved selenium $(\mu \mathrm{g} / \mathrm{L})$ & NT & 0.541 & -- & -- & -- & -- \\
\hline Suspended sediment & -5.7 & 0.049 & -6.0 & 0.156 &.- & -- \\
\hline
\end{tabular}


Table 8. Summary statistics for water-quality data used for the analysis of trend at Cheyenne River at Cherry Creek [Values are in milligrams per liter unless otherwise indicated. FAC, flow-adjusted concentration; RCD, raw concentration data; $\mu \mathrm{S} / \mathrm{cm}$, microsiemens per centimeter at 25 degrees Celsius; col/100 mL, colonies per 100 milliliters; $\mu \mathrm{g} / \mathrm{L}$. micrograms per liter; <, less than analytical reporting limit; --, rot calculated]

\begin{tabular}{|c|c|c|c|c|c|c|c|c|}
\hline Property or constituent & $\begin{array}{c}\text { Period } \\
\text { of } \\
\text { record }\end{array}$ & $\begin{array}{c}\text { Number } \\
\text { of FAC } \\
\text { obser- } \\
\text { vations }\end{array}$ & $\begin{array}{l}\text { Number } \\
\text { of RCD } \\
\text { obser- } \\
\text { vations }\end{array}$ & Median & Minimum & Maximum & $\begin{array}{l}\text { Standard } \\
\text { deviation }\end{array}$ & $\begin{array}{l}\text { Standard } \\
\text { error of } \\
\text { the mean }\end{array}$ \\
\hline Specific conductance $(\mu \mathrm{S} / \mathrm{cm})$ & $06 / 72-07 / 94$ & 205 & 205 & 2,095 & 610 & 3,900 & 604 & 42.2 \\
\hline $\mathrm{pH}$ (standard units) & $06 / 72-06 / 94$ & 44 & 44 & 8.2 & 7.2 & 9.2 & -- & -- \\
\hline $\begin{array}{l}\text { Fecal coliform bacteria } \\
\quad(\mathrm{col} / 100 \mathrm{~mL})\end{array}$ & 10/76-07/94 & 0 & 104 & 30.0 & 1.0 & 8,400 & 976 & 95.8 \\
\hline Sodium-adsorption ratio (unitless) & $06 / 72-08 / 94$ & 111 & 111 & 3.0 & 2.0 & 8.0 & 1.01 & 0.1 \\
\hline Dissolved sulfate & $06 / 72-07 / 94$ & 175 & 175 & 1,000 & 140 & 1,900 & 334 & 25.3 \\
\hline Dissolved chloride & $06 / 72-07 / 94$ & 174 & 174 & 53.0 & 3.1 & 150 & 33.1 & 2.51 \\
\hline Dissolved solids & $06 / 72-07 / 94$ & 173 & 173 & 1,680 & 310 & 3,180 & 543 & 41.3 \\
\hline Dissolved ammonia as $\mathrm{N}$ & $11 / 79-08 / 94$ & 75 & 75 & 0.1 & 0.0 & 0.6 & 0.11 & 0.02 \\
\hline Total nitrogen & 08/72-08/94 & 138 & 154 & 2.0 & 0.3 & 16.0 & 2.5 & 0.4 \\
\hline Total phosphorus & $06 / 72-07 / 94$ & 0 & 137 & 0.2 & 0.01 & 18.0 & 2.28 & 0.20 \\
\hline Dissolved arsenic $(\mu \mathrm{g} / \mathrm{L})$ & $10 / 74-07 / 94$ & 0 & 109 & 4.0 & 1.0 & 26.0 & 5.5 & 0.52 \\
\hline Dissolved manganese $(\mu \mathrm{g} / \mathrm{L})$ & $10 / 74-07 / 94$ & 0 & 122 & 20.0 & 0.2 & 460 & 67.6 & 6.1 \\
\hline Dissolved selenium $(\mu \mathrm{g} / \mathrm{L})$ & $10 / 74-07 / 94$ & 0 & 97 & 3.0 & 1.0 & 15.0 & 2.4 & 0.24 \\
\hline Suspended sediment & $07 / 72-07 / 94$ & 166 & 166 & 488 & 40.0 & 20,200 & 4,451 & 687 \\
\hline
\end{tabular}

Table 9. Summary statistics for water-quality data used for the analysis of trend at Moreau River near Whitehorse

[Values are in milligrams per liter unless otherwise indicated. FAC, flow-adjusted concentration: RCD, raw concentration data; $\mu \mathrm{S} / \mathrm{cm}$, microsiemens per centimeter at 25 degrees Celsius; col/100 mL, colonies per 100 milliliters; $\mu \mathrm{g} / \mathrm{L}$, micrograms per liter; <, less than analytical reporting limit; --, rot calculated]

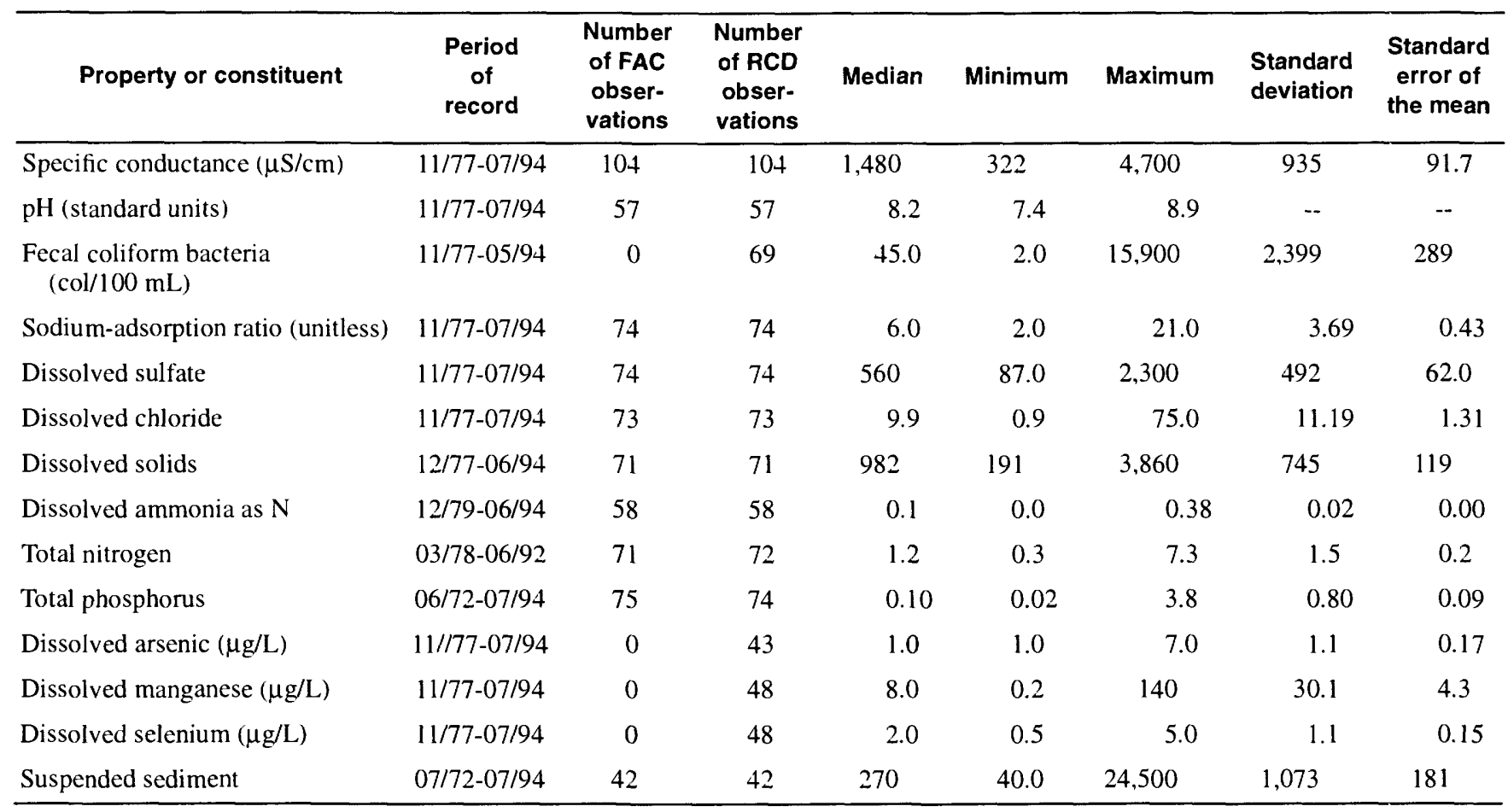


Analysis of dissolved solids concentrations data for the Cheyenne River at Cherry Creek showed an increasing trend of 1.03 percent of the median per year, or $17.3 \mathrm{mg} / \mathrm{L}$ per year for RCD. The trend test for FAC data also showed an increasing trend but was slightly lower at 0.36 percent of the median per year, or $6.9 \mathrm{mg} / \mathrm{L}$ per year.

Tobit trend analysis of arsenic concentration data for the Cheyenne River at Cherry Creek showed a decreasing trend. The RCD were decreasing at 8.29 percent of the median per year, or $0.3 \mu \mathrm{g} / \mathrm{L}$ per year. The statistically significant decreasing trend in dissolved arsenic probably results from changes made in the methods used for the disposal of mine tailings that were initiated in 1977.

Tobit trend analysis results of RCD for dissolved manganese showed decreasing trends at both the Cheyenne and Moreau River sampling stations. Decreasing trends of 5.0 percent of the median per year (or $1.0 \mu \mathrm{g} / \mathrm{L}$ per year) and 12.18 percent of the median per year (or $0.1 \mu \mathrm{g} / \mathrm{L}$ per year) were indicated for the Cheyenne and Moreau stations, respectively. It was not possible to perform trend analysis using FAC data at either station for dissolved manganese.

\section{SUMMARY}

Long-term water-quality data for two U.S. Geological Survey NASQAN stations are used to describe general water-quality conditions and to examine temporal trends in selected constituents for the Cheyenne and Moreau Rivers; data for 1972-94 for stations 06439300, Cheyenne River at Cherry Creek, and 06360500, Moreau River near Whitehorse are considered.

\section{General Water Quality}

Monthly distributions of concentrations for selected water-quality constituents are presented for each station. Descriptive statistics including mean, median, maximum, standard deviation, and standard error of the mean are summarized. Selected waterquality parameters analyzed include field parameters (specific conductance, $\mathrm{pH}$, and bacterial concentration), common ions, nutrients, and trace elements.

Water-quality data are compared to standards for drinking water and domestic water supply even though these beneficial uses do not apply for surface water at either the Cheyenne or Moreau River stations. Waterquality data also are compared to the stantards and criteria that do apply for the beneficial uses assigned for these rivers at these stations. Data are compared to standards and criteria for irrigation, wildlife propagation and stock watering, fish propagation, immersion recreation, and aquatic life values for fisheries.

No primary drinking-water standards (maximum contaminant levels-MCL's) for the constituents considered were exceeded for either river. However, the primary standard for total phosphorus entering a reservoir was equalled or exceeded in 58 and 49 percent of the samples for the Cheyenne and Moreau River stations, respectively.

Secondary standards (secondary maximum contaminant levels-SMCL's) for drinking-water supplies for dissolved sulfate were equalled or exceeded 100 percent of the time for the Cheyenne River station and 89 percent of the time for the Moreau River station. Standards for domestic supplies for dissolved sulfate were equalled or exceeced 85 and 52 percent of the time at the Cheyenne and Moreau River stations, respectively. Various exceedances of secondary standards for dissolved solids, fecal coliform bacteria, $\mathrm{pH}$, and manganese also were noted.

The standard for irrigation for sodium-adsorption ratio was equalled or exceeded 1 and 25 percent of the time for the Cheyenne and Moreau River stations, respectively. The standard for specific conductance was equalled or exceeded 14 and 24 percent of the time for the Cheyenne and Moreau River stations, respectively.

Standards for wildlife propagation and stock watering generally were met. Standards for dissolved solids were equalled or exceeded 4 percent of the time for the Cheyenne River station and 11 pe"cent of the time for the Moreau River station. The standard for $\mathrm{pH}$ was equalled or exceeded 1 percent of the time for the Cheyenne River station, and the standard for specific conductance was equalled or exceeded 2 percent of the time for the Moreau River station.

Standards for warmwater permanent and marginal fish propagation were frequentl:' exceeded for suspended sediment. For the Cheyenne River, the permanent standard was equalled or exceeded 90 percent of the time, and the marginal standard was equalled or exceeded 71 percent of the time. For the Moreau River, the permanent and margiral standards were equalled or exceeded 92 and 82 percent of the time, respectively. Ammonia standards for the 
Cheyenne River were equalled or exceeded 57 percent of the time for permanent and 55 percent of the time for marginal. For the Moreau River, the permanent and marginal standards were equalled or exceeded 66 and 60 percent of the time, respectively. The criteria for warmwater permanent fish propagation for $\mathrm{pH}$ was equalled or exceeded only 1 percent of the time for the Cheyenne River station and was not equalled or exceeded for the Moreau River station.

The standard for chronic toxicity of selenium for aquatic life for fisheries was equalled or exceeded 20 percent of the time at the Cheyenne River station, and 4 percent of the time at the Moreau River station. The standard for acute toxicity of selenium was not equalled or exceeded at either station. The standard for fecal coliform for immersion recreation waters was equalled or exceeded 10 percent of the time at the Cheyenne River station, and 25 percent of the time at the Moreau River station.

\section{Trends}

The Seasonal Kendall test for raw concentration data (RCD) or flow-adjusted concentration (FAC) data, or the Tobit test for RCD, were used to determine trend. Unadjusted constituent concentration data were plotted against time, and a trend line was calculated using either the Seasonal Kendall or Tobit test. The trend test that provided the most statistically significant p-value was selected. Trends with p-values less than or equal to 0.050 were considered to be statistically significant. Caution should be used when assessing the magnitude of trends with p-values determined not to be significant. Whenever possible, the results of the Seasonal Kendall test for FAC data are preferred to define trends.

Trend-analysis results for water-quality concentration data collected from the Cheyenne River at Cherry Creek showed that of the 14 constituents considered, five had trends that were determined to be statistically significant, five were not statistically significant, and four showed no trend present. Of the five statistically significant trends, three were increasing, and two were decreasing. Increasing trends included dissolved sulfate, dissolved chloride, and dissolved solids. Increasing trends for these constituents may be related, because increasing concentrations of dissolved sulfate and chloride would have a similar effect on dissolved solids. However, the potential causes for increasing trends for these constituents were not investigated. The two statistically significant decreasing trends included dissolved arsenic and dissolved manganese. Concentrations of dissolved arsenic in the Cheyenne River are known to have been affected by mining practices in the Black Hills. The statistically significant decreasing trend in dissolved arsenic probably results from changes made in the methods used for the disposal of mine tailings. Potential causes for the decreasing trend in dissolved manganese were not investigated.

Trend-analysis results for water-quality concentration data collected from the Moreau River near Whitehorse showed that, of the 14 constituents considered, one was determined to be statistically significant, 10 were not statistically significant, and three showed no trend present. The only statistically significant trend showed a decrease in dissolved manganese. Potential causes for the decreasing trend in dissolved manganese were not investigated.

\section{REFERENCES}

Britton, L.J., Goddard, K.E., and Briggs, J.C., 1983, Quality of rivers of the United States, 1976 water year-Based on the National Stream Quality Accounting Network (NASQAN): U.S. Geological Survey Open-File Report 80-594, 423 p.

Cleveland, W.S., 1979, Robust locally weighted regression and smoothing scatterplots: Journal of America 7 Statistical Association, v. 74, no. 368, p. 829-8:6.

Cohen, A.C., Jr., 1976, Progressively censored samp'ing in the three parameter log-normal distribution: Technometrics, v. 18, no. 1, p. 99-103.

Cohn, T.A., 1988, Adjusted maximum likelihood estimation of the moments of lognormal populations from type I censored samples: U.S. Geological Survey Open-File Report 88-350, 34 p.

Fenneman, N.M., 1946, Physical divisions of the United States: U.S. Geological Survey map prepared in cooperation with the Physiographic Commission, U.S. Geological Survey, scale 1:700,000 (reprinted 1964).

Fishman, M.J., and Friedman, L.C., eds., 1989, Methods for determination of inorganic substances in water and fluvial sediments: U.S. Geological Survey Tecr niques of Water-Resources Investigations, book 5, cha?. A1, $545 \mathrm{p}$.

Goddard, K.E., 1989, Composition, distribution, and hydrologic effects of contaminated sediments resulting from the discharge of gold milling wastes to Whitewood Creek at Lead and Deadwood, South Dakota: U.S. Geological Survey Water-Resources Investigations Report 87-4051, $76 \mathrm{p}$. 
Greene, E.A., Sowards, C.L., and Hansmann, E.W., 1990. Reconnaissance investigation of water quality, bottom sediment, and biota associated with irrigation drainage in the Angostura Reclamation Unit, southwestern South Dakota, 1988-89: U.S. Geological Survey WaterResources Investigations Report 90-4152, 75 p.

Helsel, D.R., and Gilliom, R.J., 1985, Estimation of distributional parameters for censored trace-level water-quality data; II, Verification and applications: U.S. Geological Survey Open-File Report 85-86, 21 p.

Helsel, D.R., and Hirsch, R.M., 1992, Statistical methods in water resources: Studies in Environmental Science 49 , Amsterdam, Netherlands, Elsevier Science, 522 p.

Hem, J.D., 1985, Study and interpretation of the chemical characteristics of natural water: U.S. Geological Survey Water-Supply Paper 2254, 263 p.

Hirsch, R.M., Slack, J.R., and Smith, R.A., 1982, Techniques of trend analysis for monthly water-quality data: Water Resources Research, v. 18, no. 6, p. 107-121.

Howells, Lewis, 1979, Geohydrology of the Cheyenne River Indian Reservation, South Dakota: U.S. Geological Survey Hydrologic Atlas HA-585, 3 sheets.

Kendall, M.G., 1975, Rank correlation methods (4th ed.): London, Charles Griffin.

Lucius, J.E., Olhoeft, G.R., Hill, P.L., and Duke, S.K., 1992, Properties and hazards of 108 selected substances- 1992 edition: U.S. Geological Survey Open-File Report 92-527, $554 \mathrm{p}$.

Mann, H.B., 1945, Non-parametric test against trend: Econometrica, v. 13, p. 245-259.

Marron, D.C., 1988, Transport and flood-plain storage of metals associated with sediment downstream from Lead, South Dakota, in Mallard, G.E., ed., U.S. Geological Survey toxic substances hydrology program-Surface-water contamination-Proceedings of the technical meeting, Denver, Colorado, February 2-4, 1987: U.S. Geological Survey Open-File Report 87-764, 160 p.

McKallip, T.E., 1993, South Dakota stream water quality, in U.S. Geological Survey, National water summary 1990-91-Hydrologic events and stream water quality: U.S. Geological Survey Water-Supply Paper 2400, p. 491-497.

Rainwater, F.H., and Thatcher, L.L., 1960, Methods for collection and analysis of water samples: U.S. Geological Survey Water-Supply Paper 1454 , p. 275-278.

Roberts, Kris, Stearns, Bruce, and Francis, R.L., 1985, Investigation of arsenic in southeastern North Dakota ground water, A Superfund Remedial Investigation Report: North Dakota State Department of Health, Bismarck, Superfund Cooperative Agreement No. V008414-01, $225 \mathrm{p}$.
Roddy, W.R., Greene, E.A., and Sowards, C.L., 1991,

Reconnaissance investigation of water quality, bottom sediment, and biota associated with irrigation drainage in the Belle Fourche Reclamation Project, western South Dakota, 1988-89: U.S. Geological Survey Water-Resources Investigations Report 90-4192, $113 \mathrm{p}$.

Schertz, T.L., Alexander, R.B., and Ohe, D.J., 1991, The computer program EStimate TREND (ESTREND), a system for the detection of trends in water-quality data: U.S. Geological Survey Water-Resourc's Investigations Report 91-4040, 63 p.

Skougstad, M.V., Fishman, M.J., Freidman, L.C., Erdmann, D.E., and Duncan, S.S., eds., 1979, Methods for determination of inorganic substances in water and fluvial sediments: U.S. Geological Sur'/ey Techniques of Water Resources Investigations, boo 5 , chap. Al, $626 \mathrm{p}$.

South Dakota Crop and Livestock Reporting Service, 1985, South Dakota agriculture-1979-85: 100 p.

South Dakota Department of Environment and Natural Resources, 1996, The 1996 South Dakota report to Congress, 305(b) Water quality assessment: Pierre, South Dakota: 254 p.

U.S. Department of Agriculture, 1976, South Dakota land use-1975 estimates: Soil Conservaticn Service, $63 \mathrm{p}$.

U.S. Department of Commerce, 1990a, Climatological data annual summary for Wyoming: v. 99, no. 13, 31 p.

1990b, Climatological data annual summary for South Dakota: v. 95, no. 13, 4 p.

U.S. Environmental Protection Agency, 1986, Maximum contaminant levels (subpart B of part 141), National interim primary drinking water regulations: U.S. Code of Federal Regulations, Title 40, Part 141, p. 524-528.

-1990, Drinking water regulations and health advisories: Office of Drinking Water, U.S. Environmental Agency Report, p. 1-10.

1996, Drinking water regulations and health advisories: Washington D.C, Office of Water, February 1996, EPA 822-R-96-001.

U.S. Geological Survey, 1975, Mineral and water resources of South Dakota: U.S. Congress, 94th, 1st Session, Interior and Insular Affairs Committee Print, $313 \mathrm{p}$.

Wetzel, R.G, and Likens, G.E., 1979, Limnological analyses: Philadelphia, W.B. Saunders Company, $357 \mathrm{p}$. 
SUPPLEMENTAL INFORMATION 



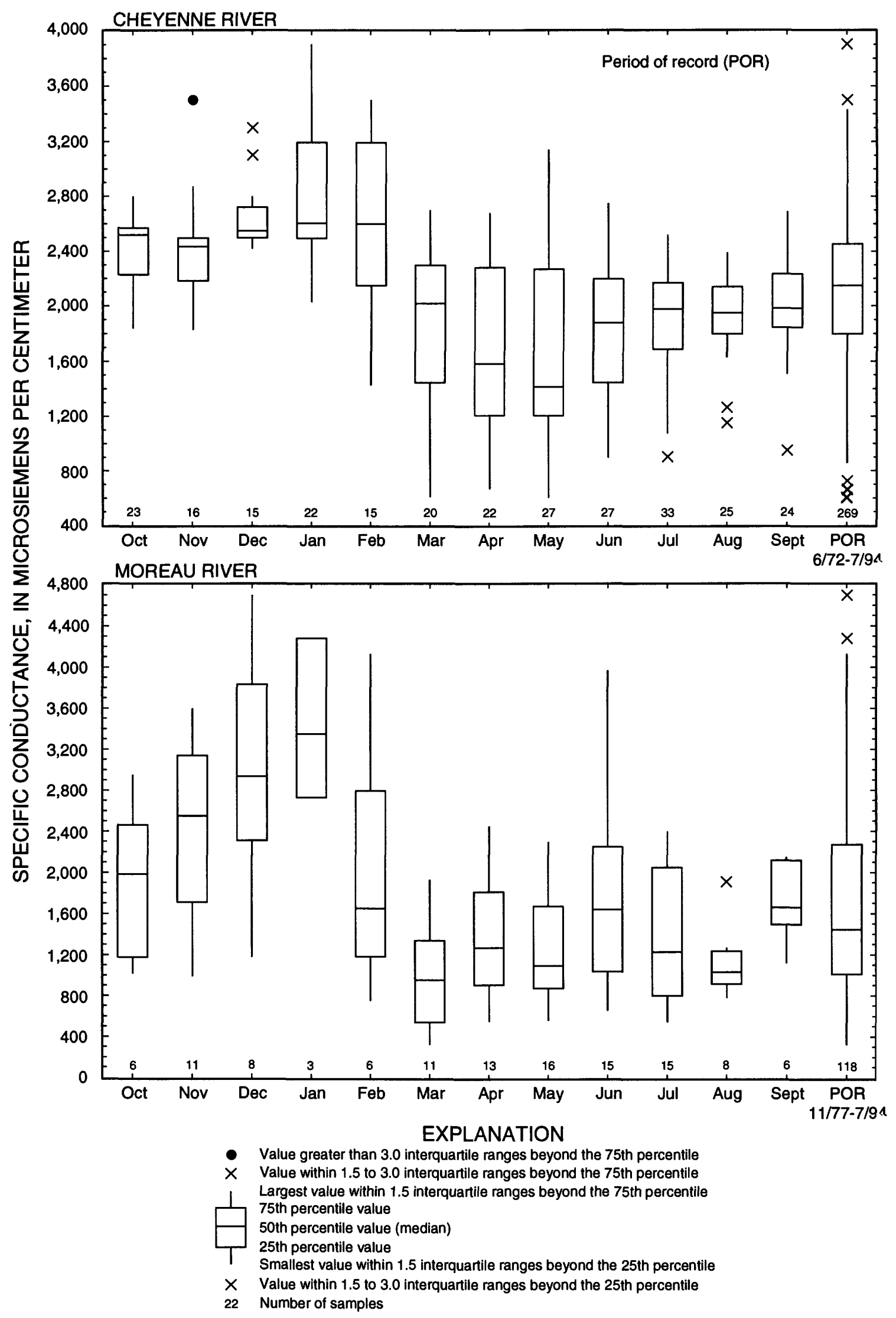

Figure 6. Ranges in specific conductance values for Cheyenne River at Cherry Creek and Moreau River near Whitehorse. 


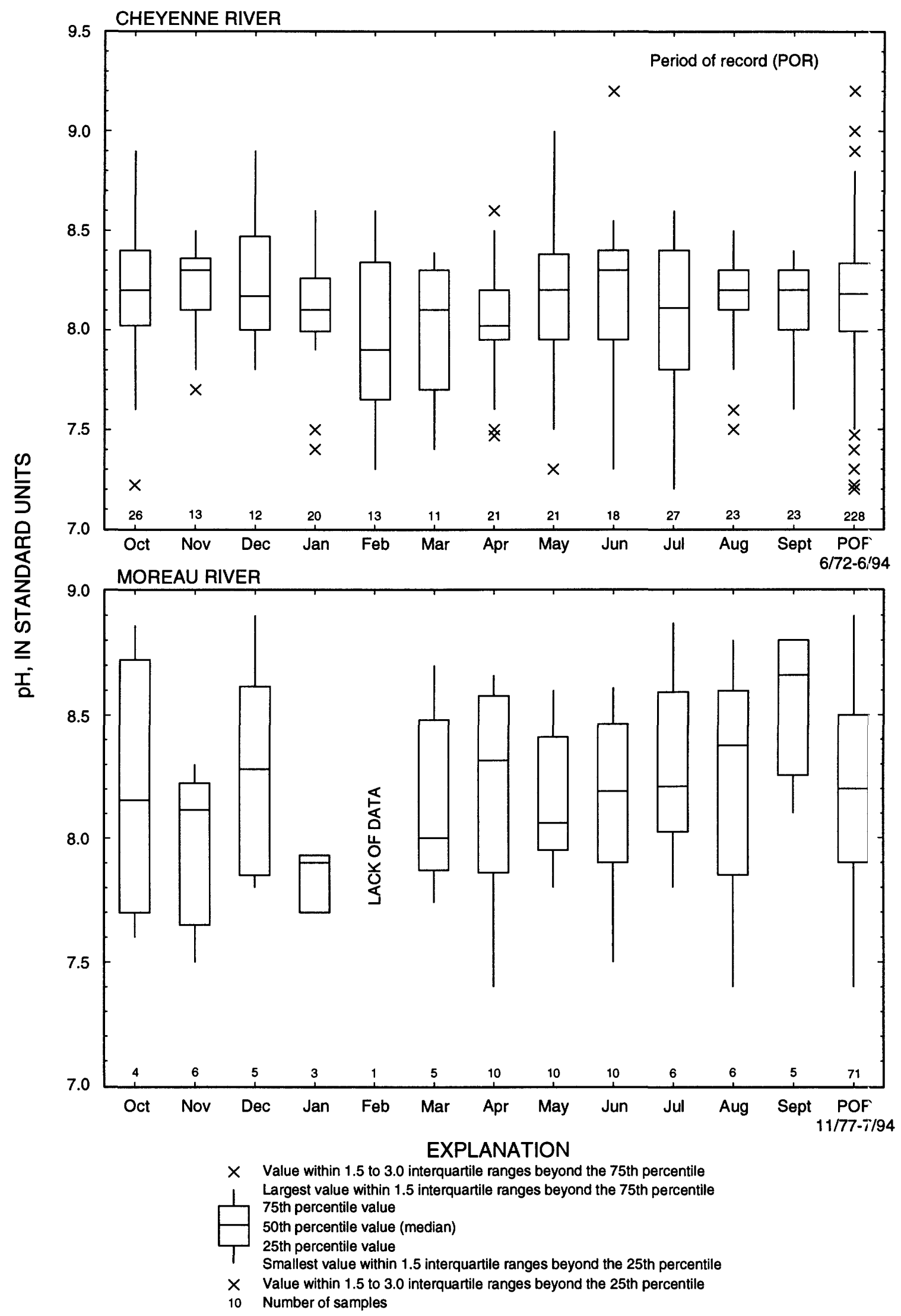

Figure 7. Ranges in pH values for Cheyenne River at Cherry Creek and Moreau River near Whitehorse. 


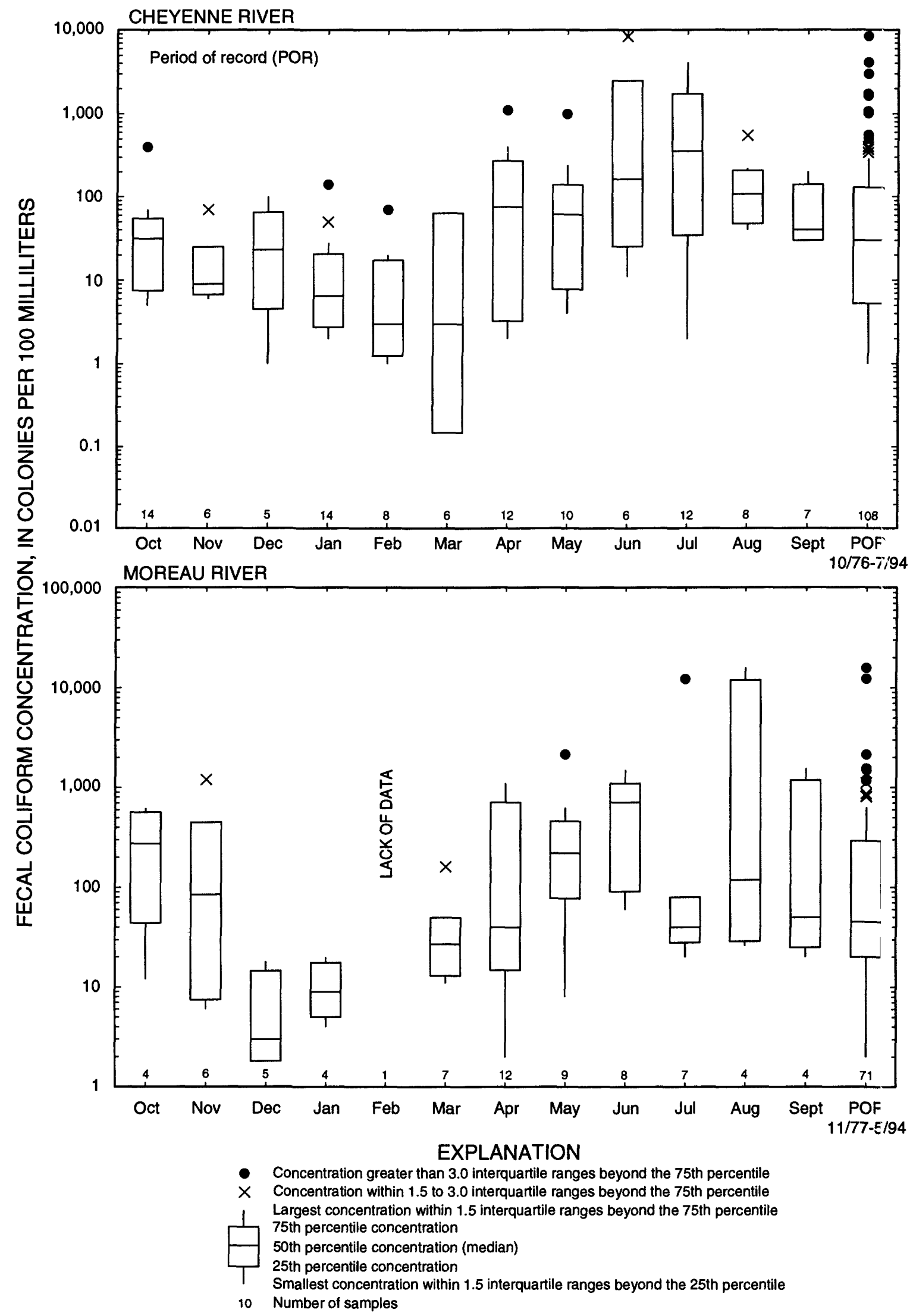

Figure 8. Ranges in concentrations of fecal coliform for Cheyenne River at Cherry Creek and Moreau Rivar near Whitehorse. 


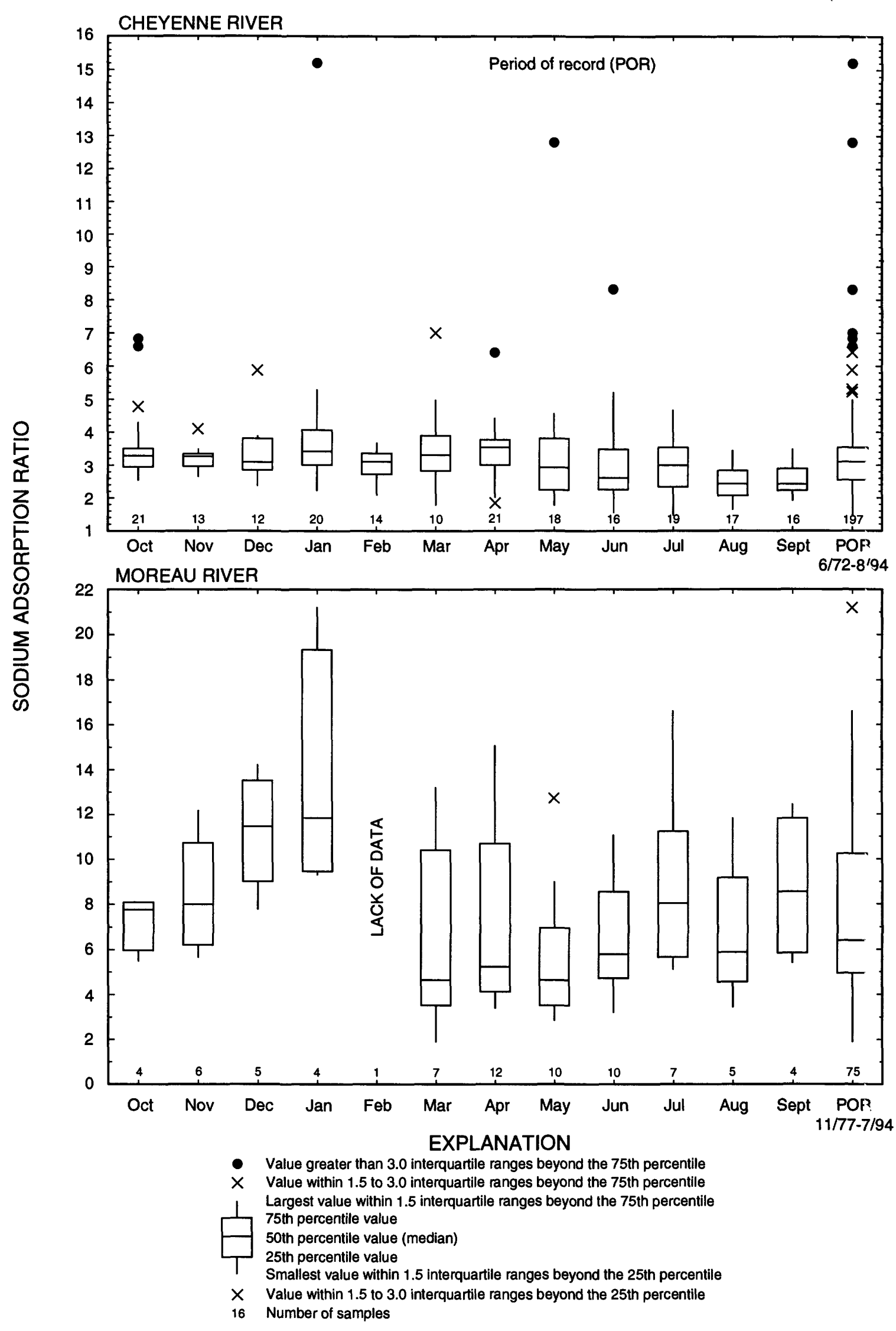

Figure 9. Ranges in sodium-adsorption values for Cheyenne River at Cherry Creek and Moreau River roar Whitehorse. 


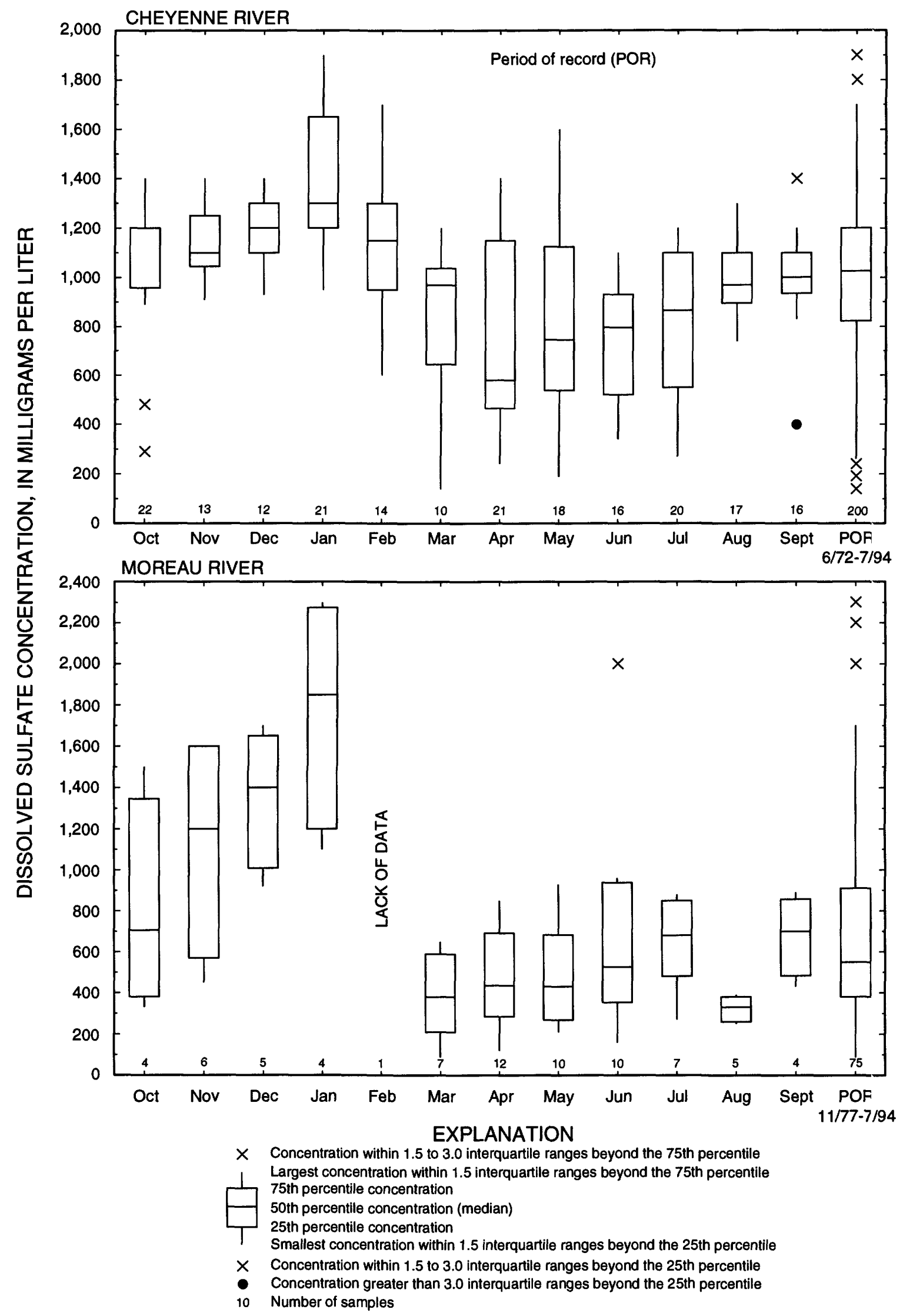

Figure 10. Ranges in concentrations of dissolved sulfate for Cheyenne River at Cherry Creek and Moreau River near Whitehorse. 


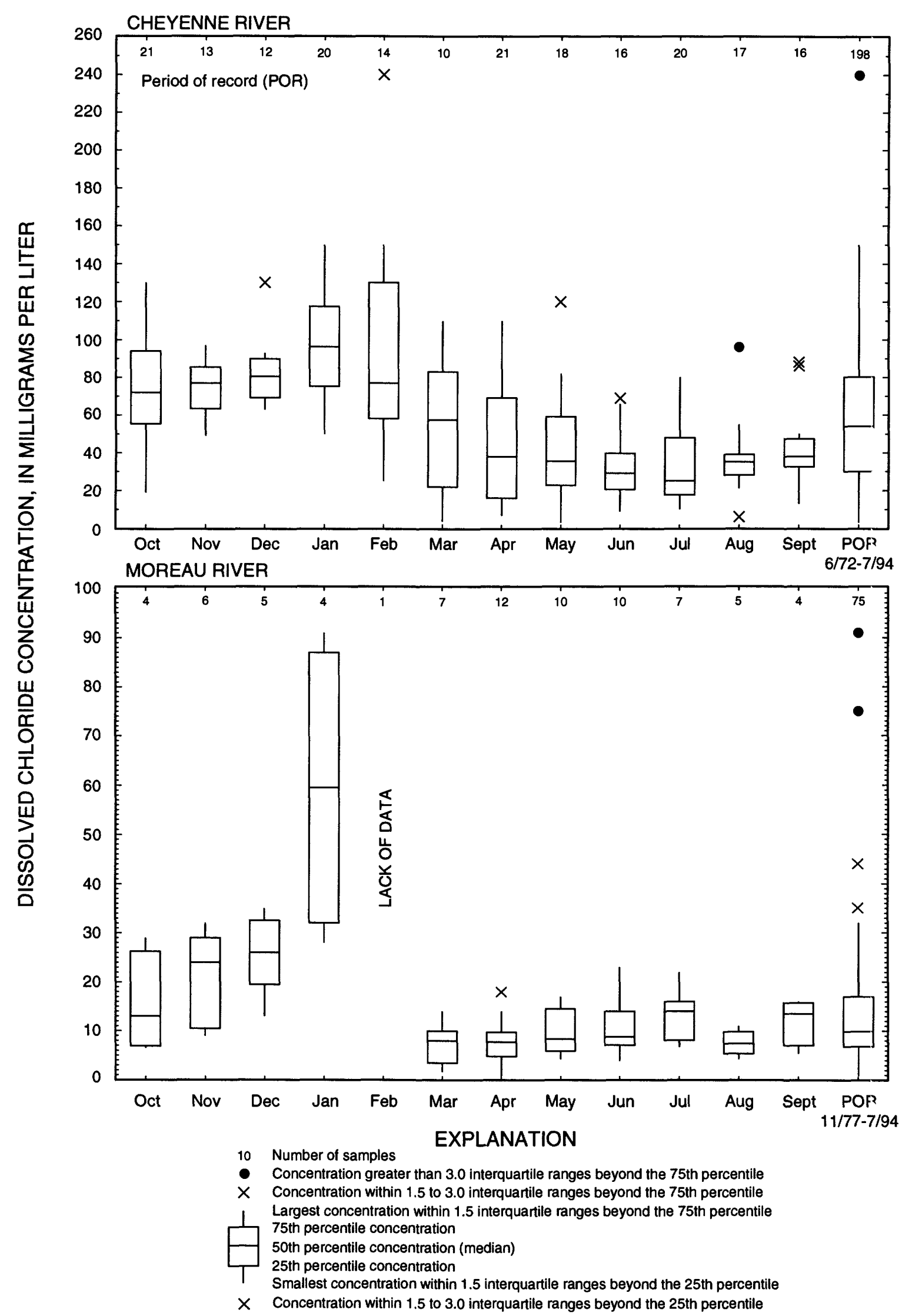

Figure 11. Ranges in concentrations of dissolved chloride for Cheyenne River at Cherry Creek and More zu River near Whitehorse. 


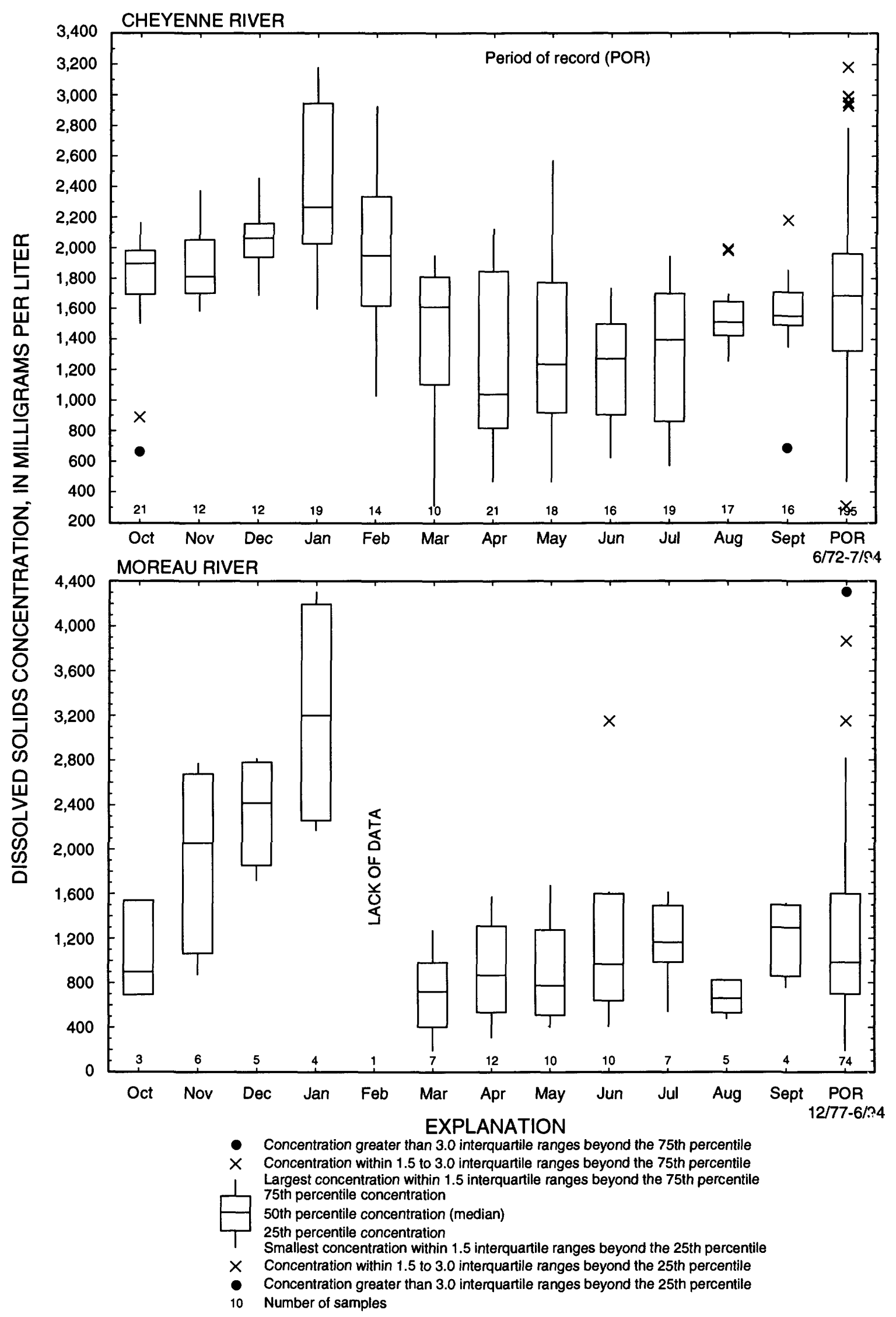

Figure 12. Ranges in concentrations of dissolved solids for Cheyenne River at Cherry Creek and Moreau River near Whitehorse. 


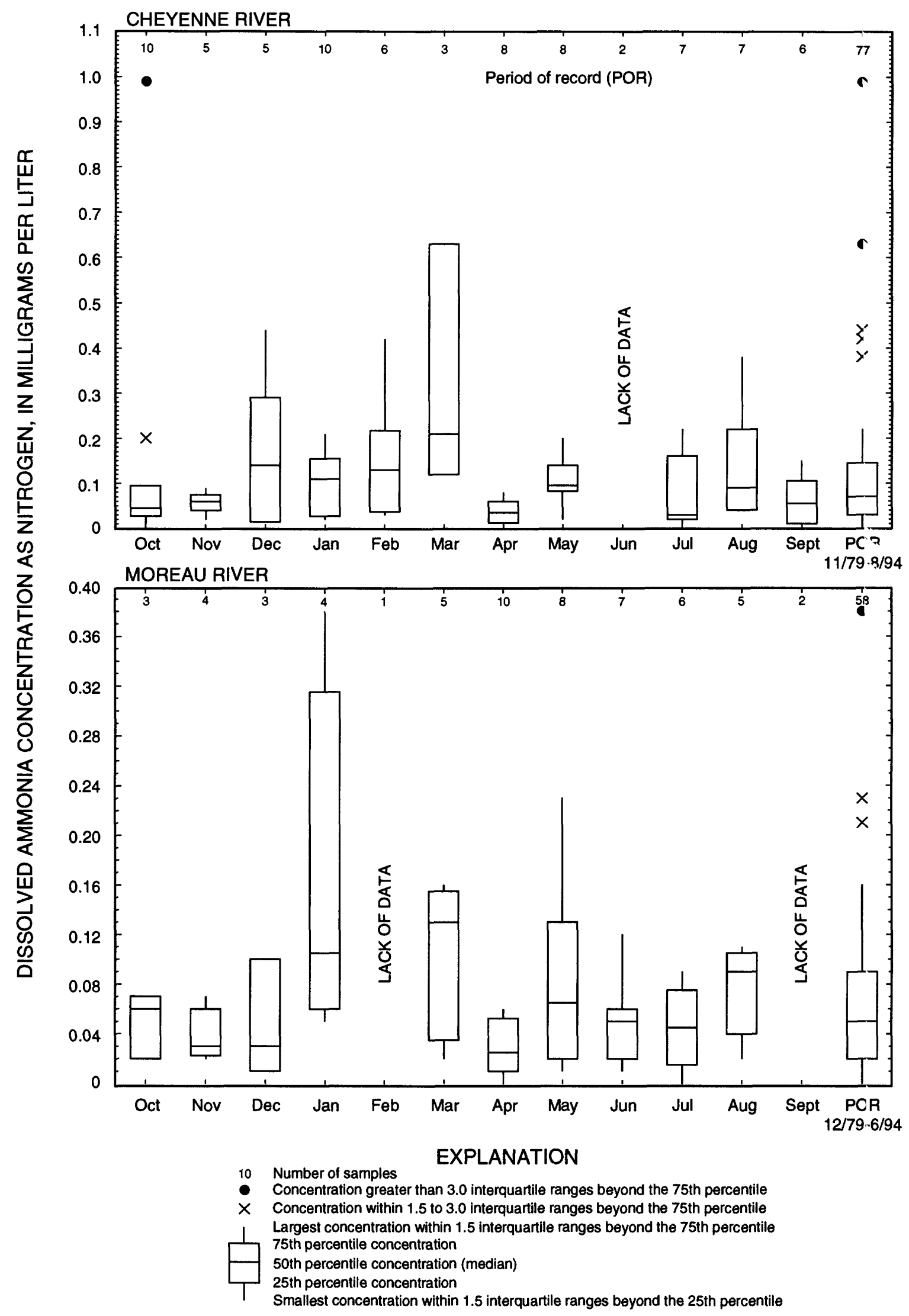

Figure 13. Ranges in concentrations of dissolved ammonia as nitrogen for Cheyenne River at Cherry $C$ sek and Moreau River near Whitehorse. 


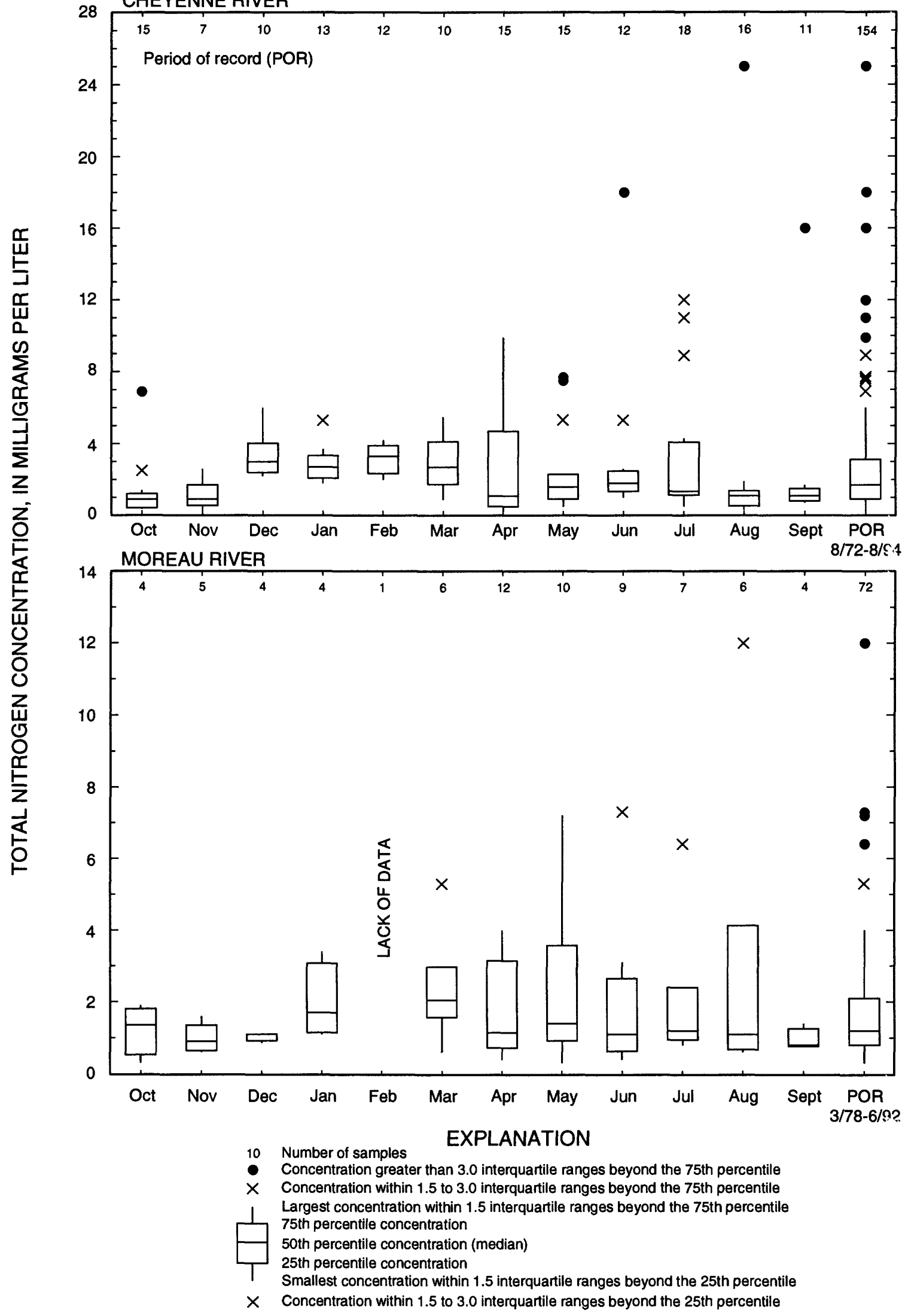

Figure 14. Ranges in concentrations of total nitrogen for Cheyenne River at Cherry Creek and Moreau River near Whitehorse. 


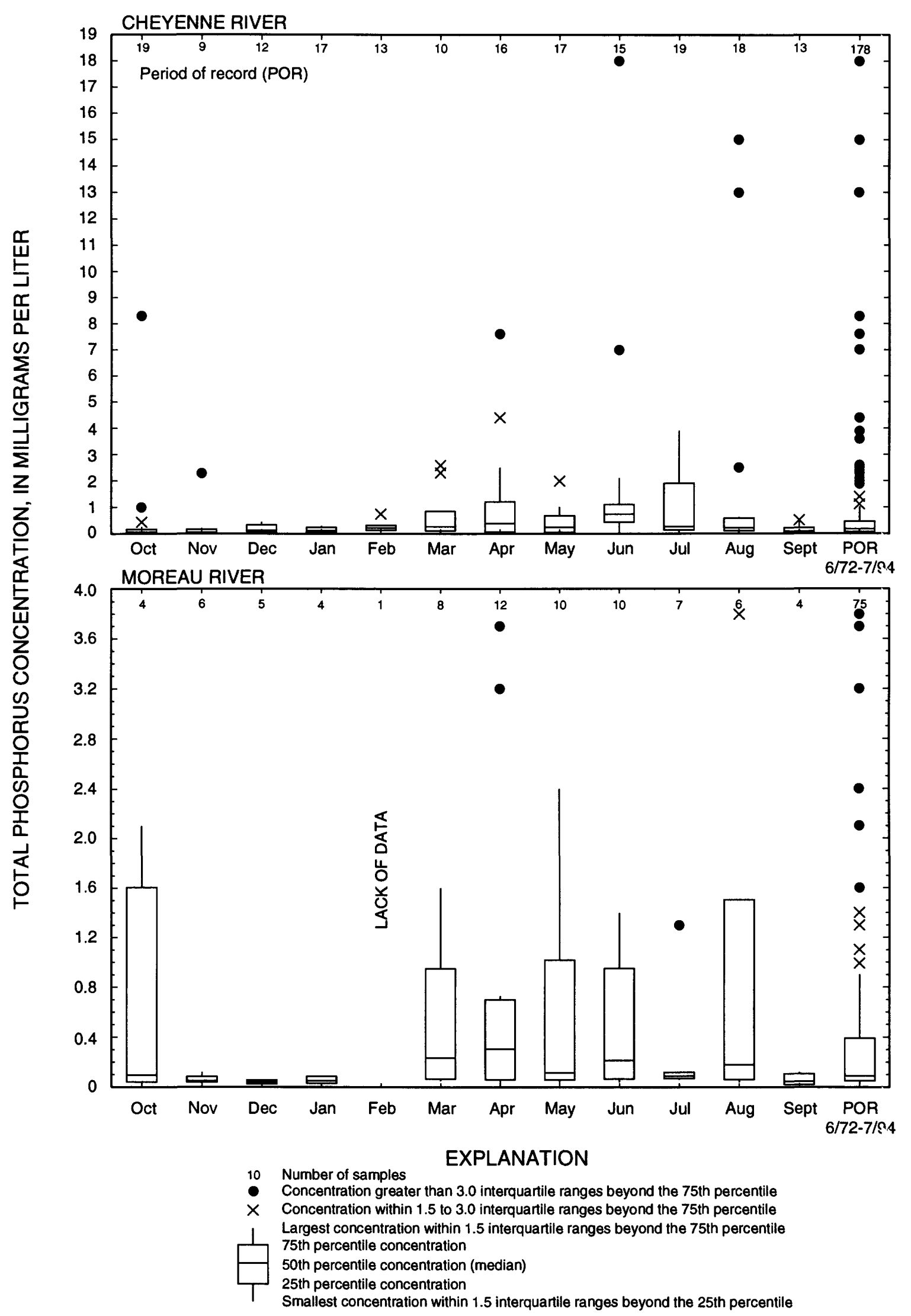

Figure 15. Ranges in concentrations of total phosphorus for Cheyenne River at Cherry Creek, and Moreau River near Whitehorse. 


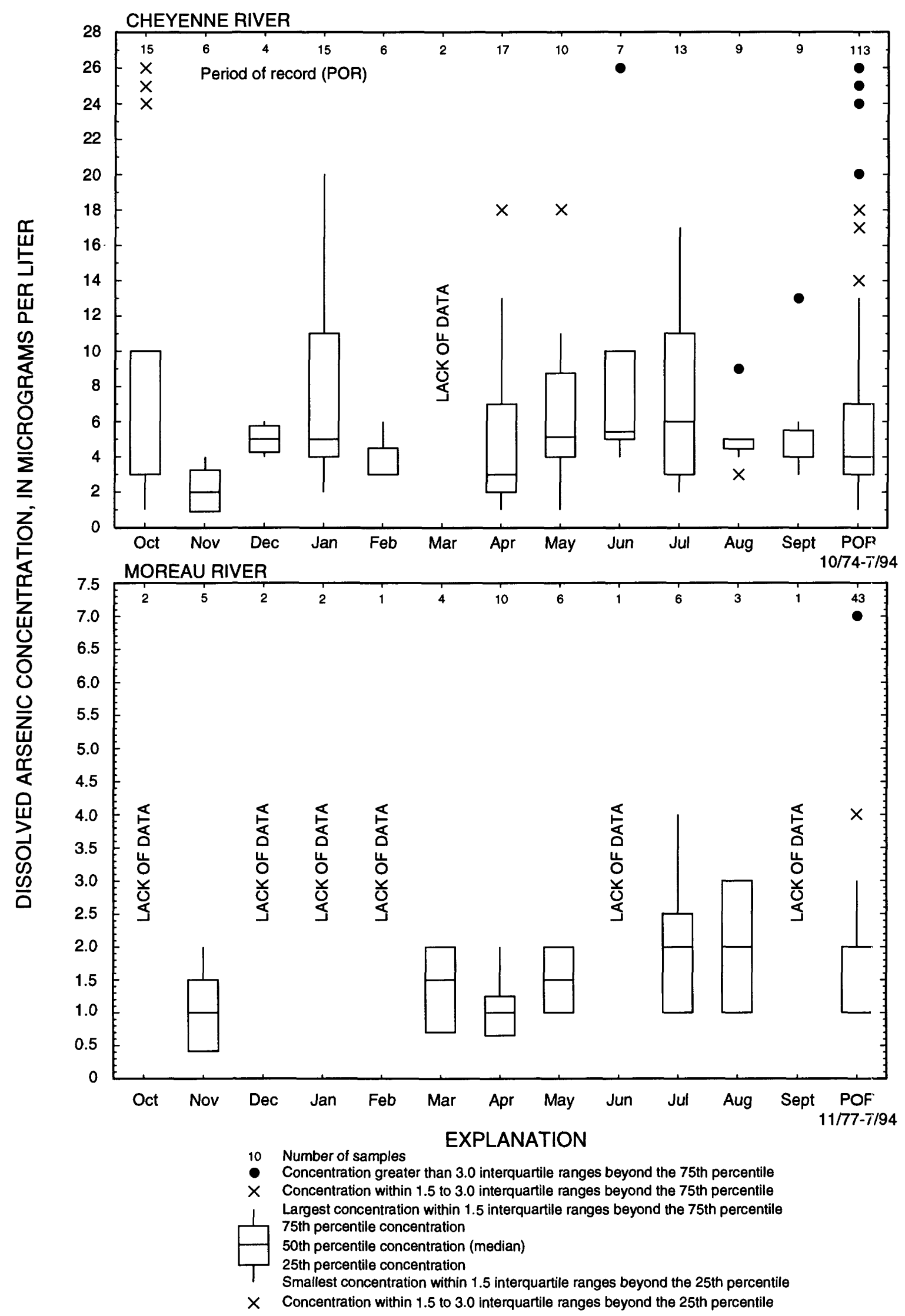

Figure 16. Ranges in concentrations of dissolved arsenic for Cheyenne River at Cherry Creek, and Moreau River near Whitehorse. 


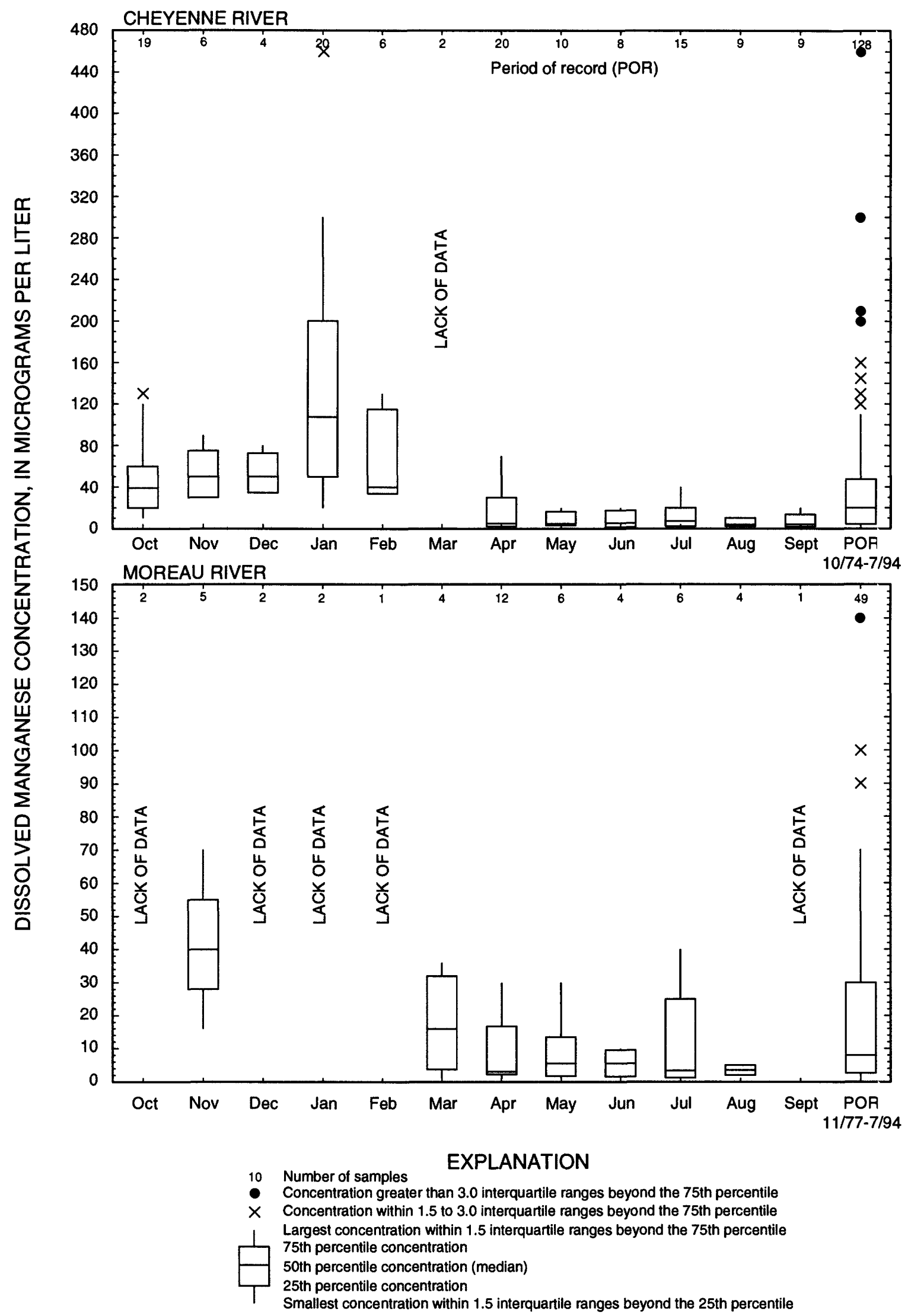

Figure 17. Ranges in concentrations of dissolved manganese for Cheyenne River at Cherry Creek and Moreau River near Whitehorse. 


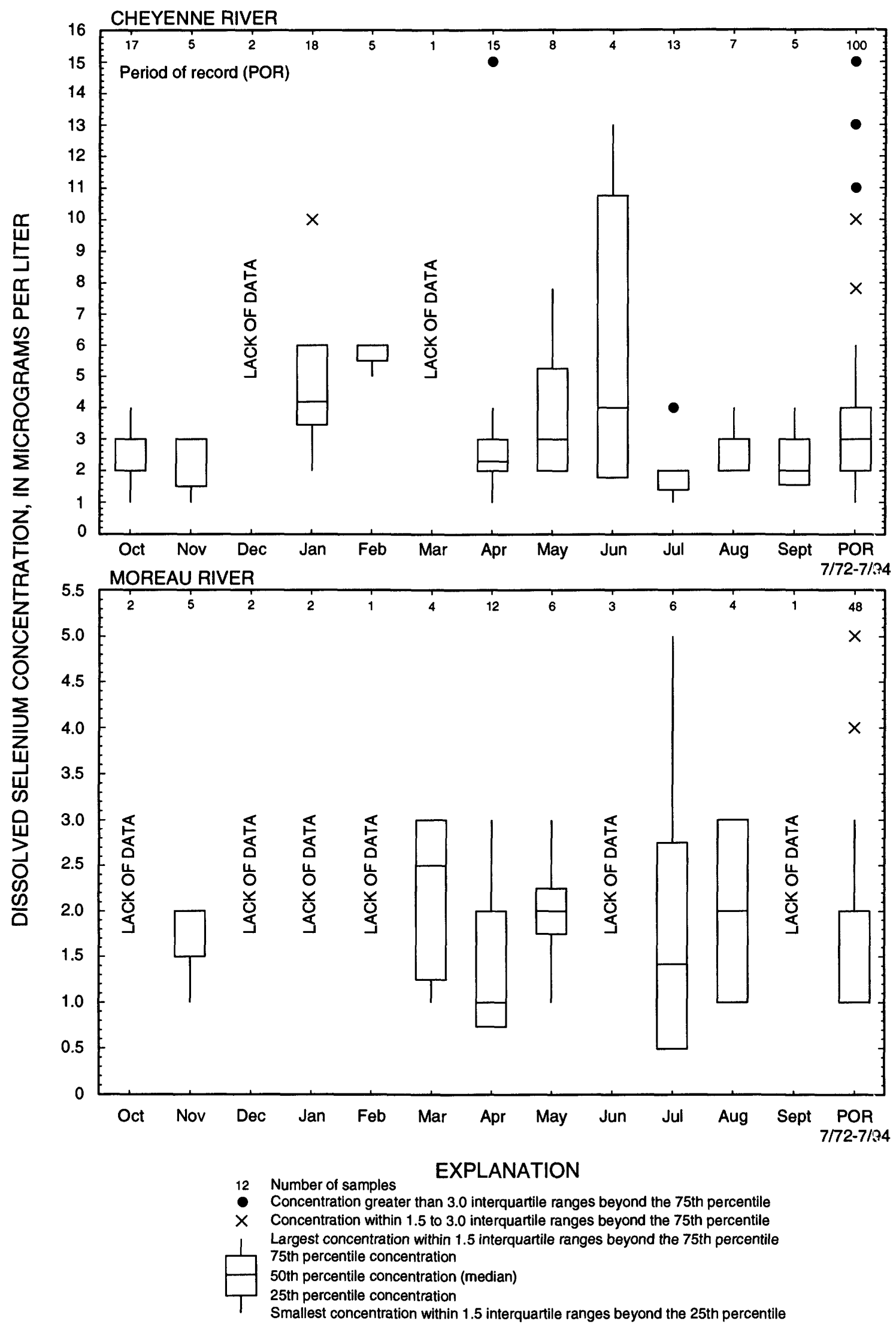

Figure 18. Ranges in concentrations of dissolved selenium for Cheyenne River at Cherry Creek and Moreau River near Whitehorse. 


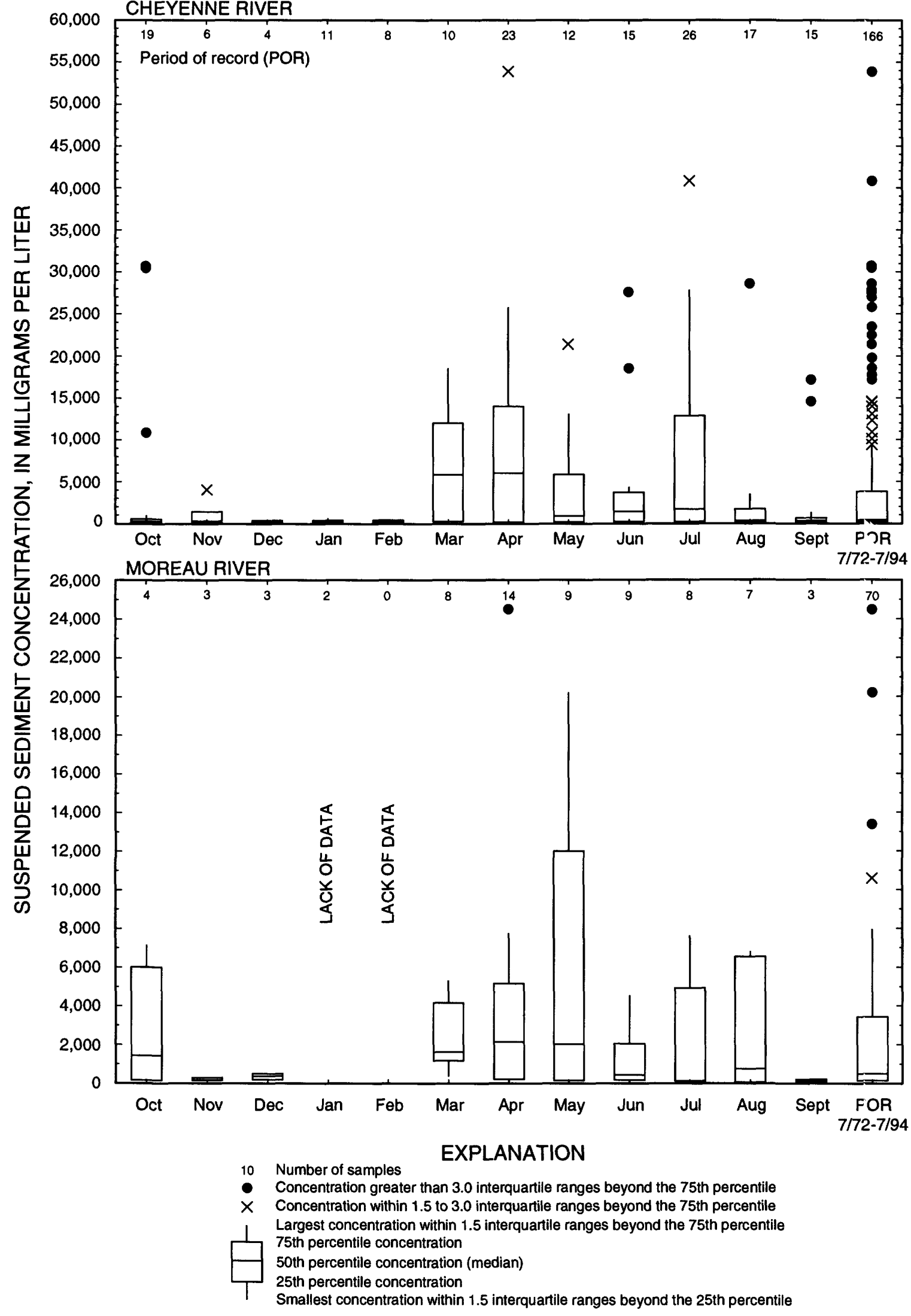

Figure 19. Ranges in concentrations of suspended sediment for Cheyenne River at Cherry Creek and Moreau River near Whitehorse. 


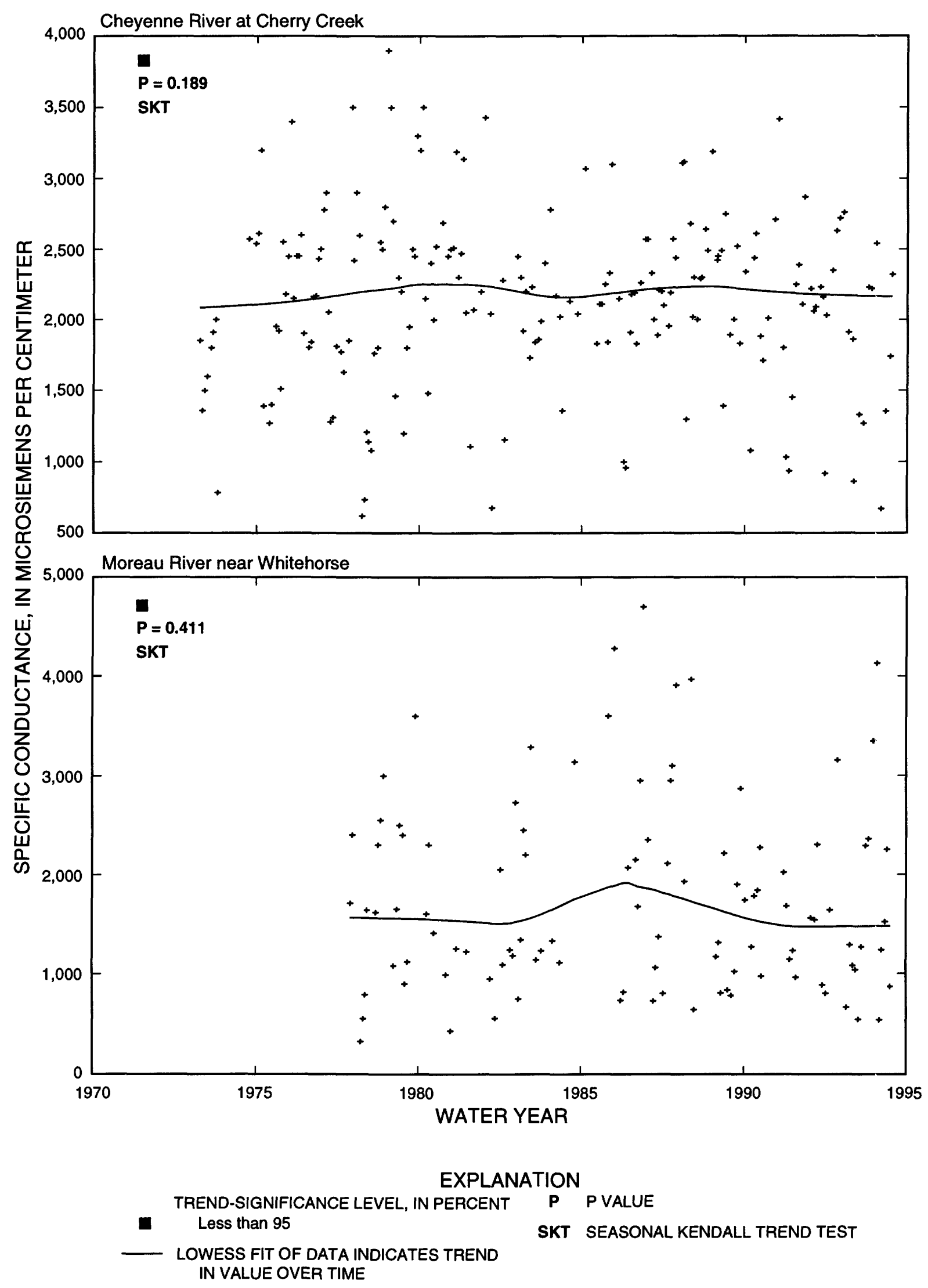

Figure 20. Temporal trends in specific conductance for flow-adjusted values, using the seasonal Kendall test. 


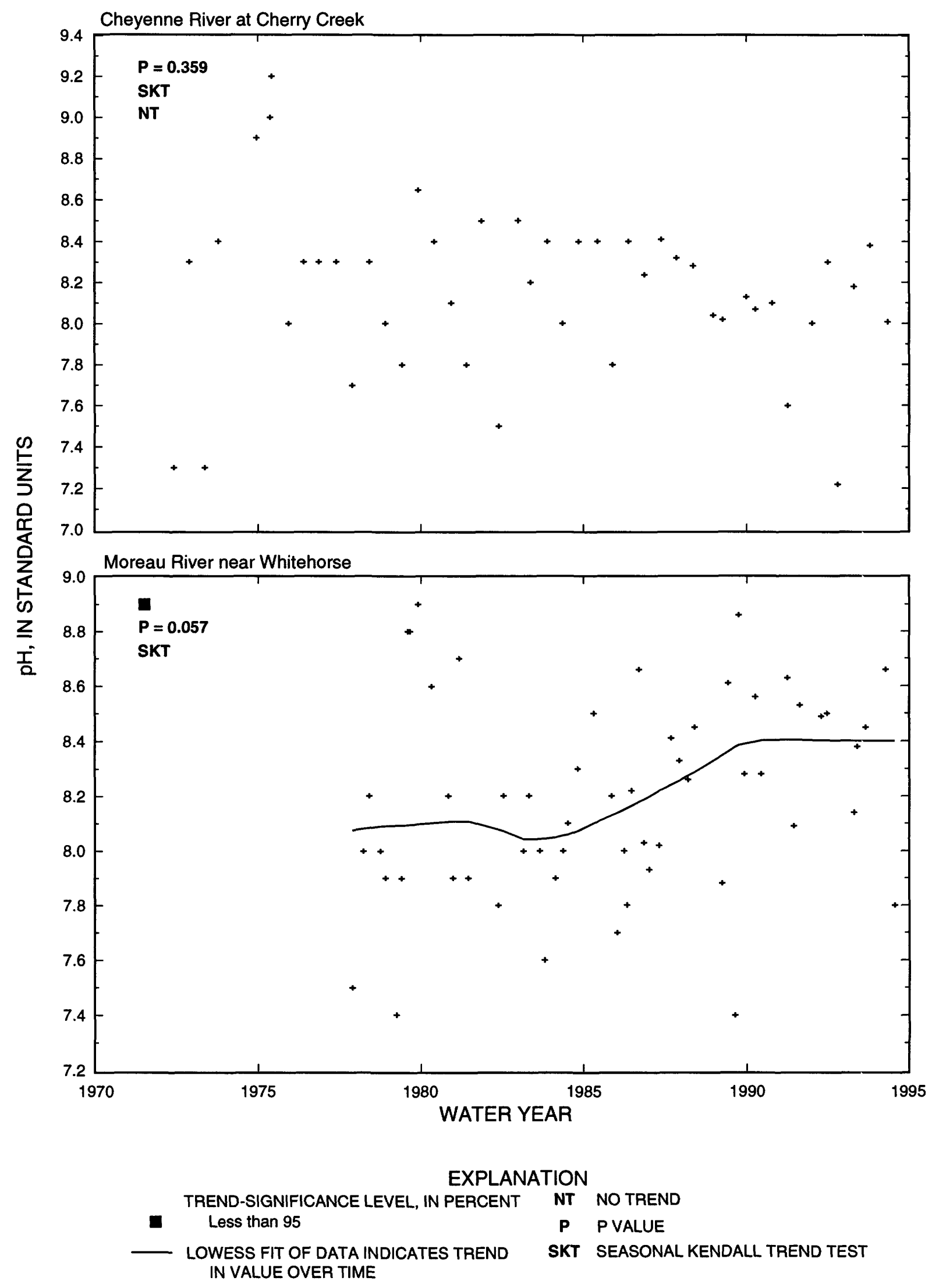

Figure 21. Temporal trends in $\mathrm{pH}$ for flow-adjusted values, using the seasonal Kendall test. 

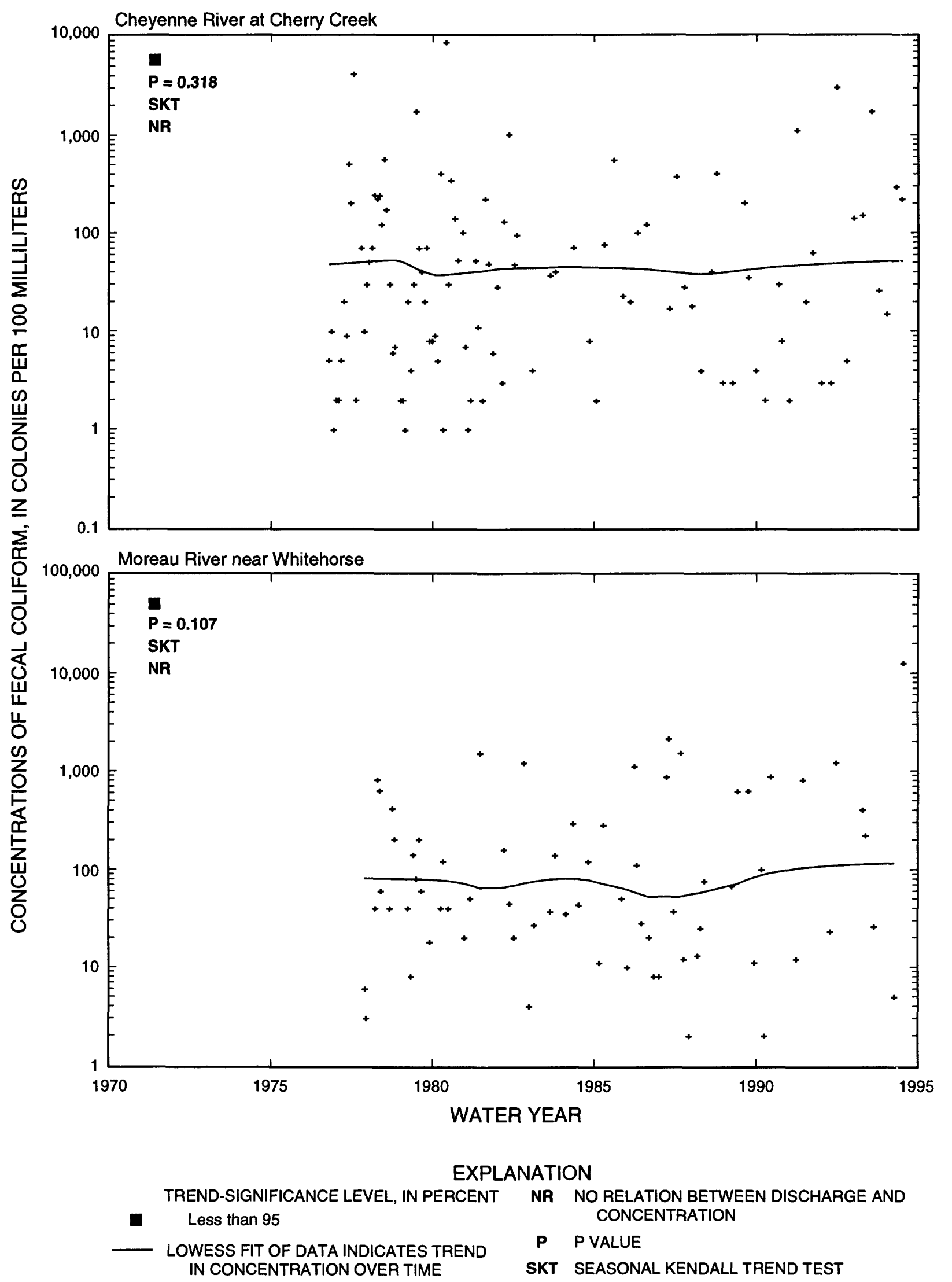

Figure 22. Temporal trends in fecal coliform for raw concentrations, using the seasonal Kendall test. 


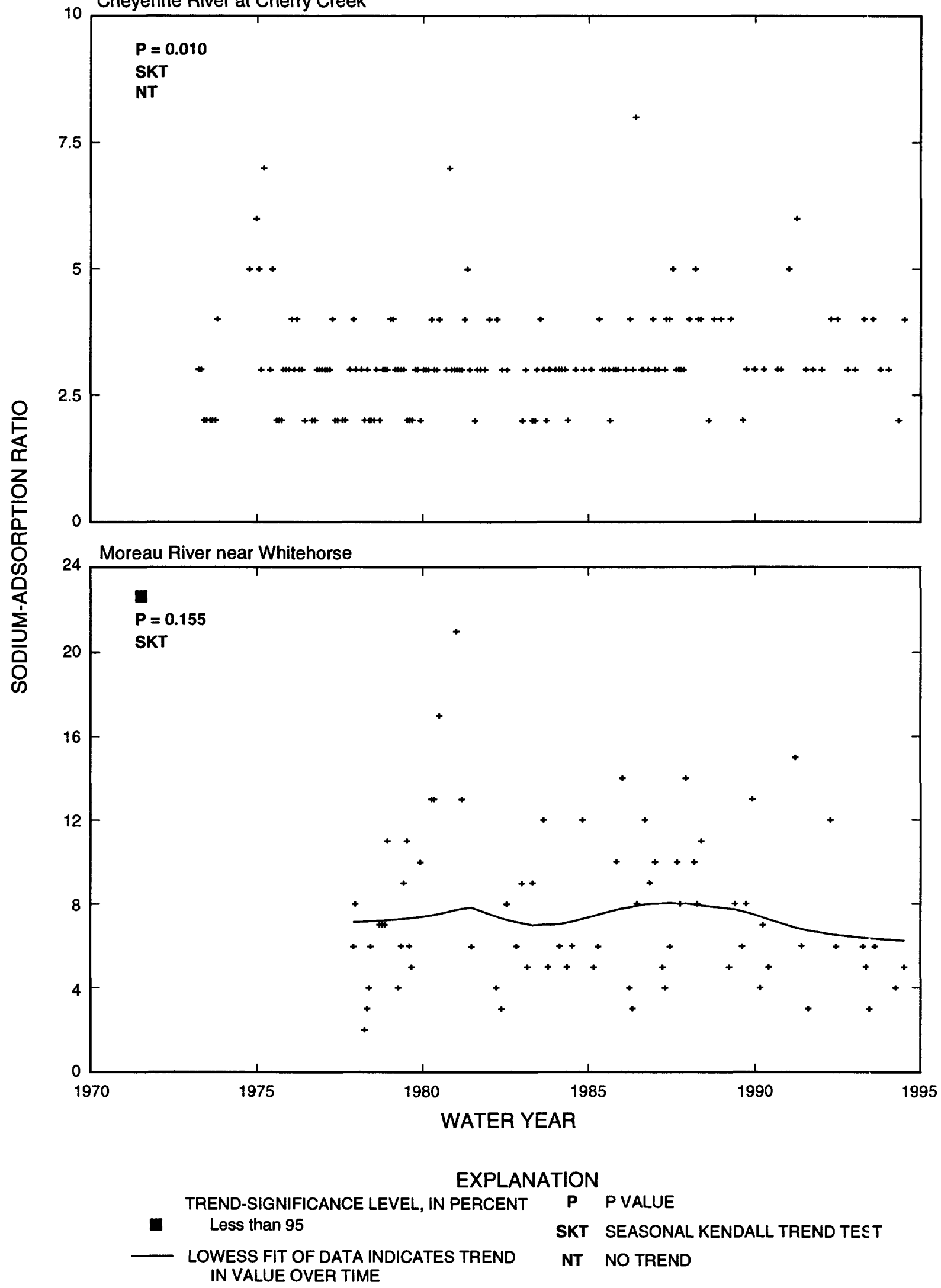

Figure 23. Temporal trends in sodium-adsorption ratio for flow-adjusted values, using the seasonal Kentall test. 


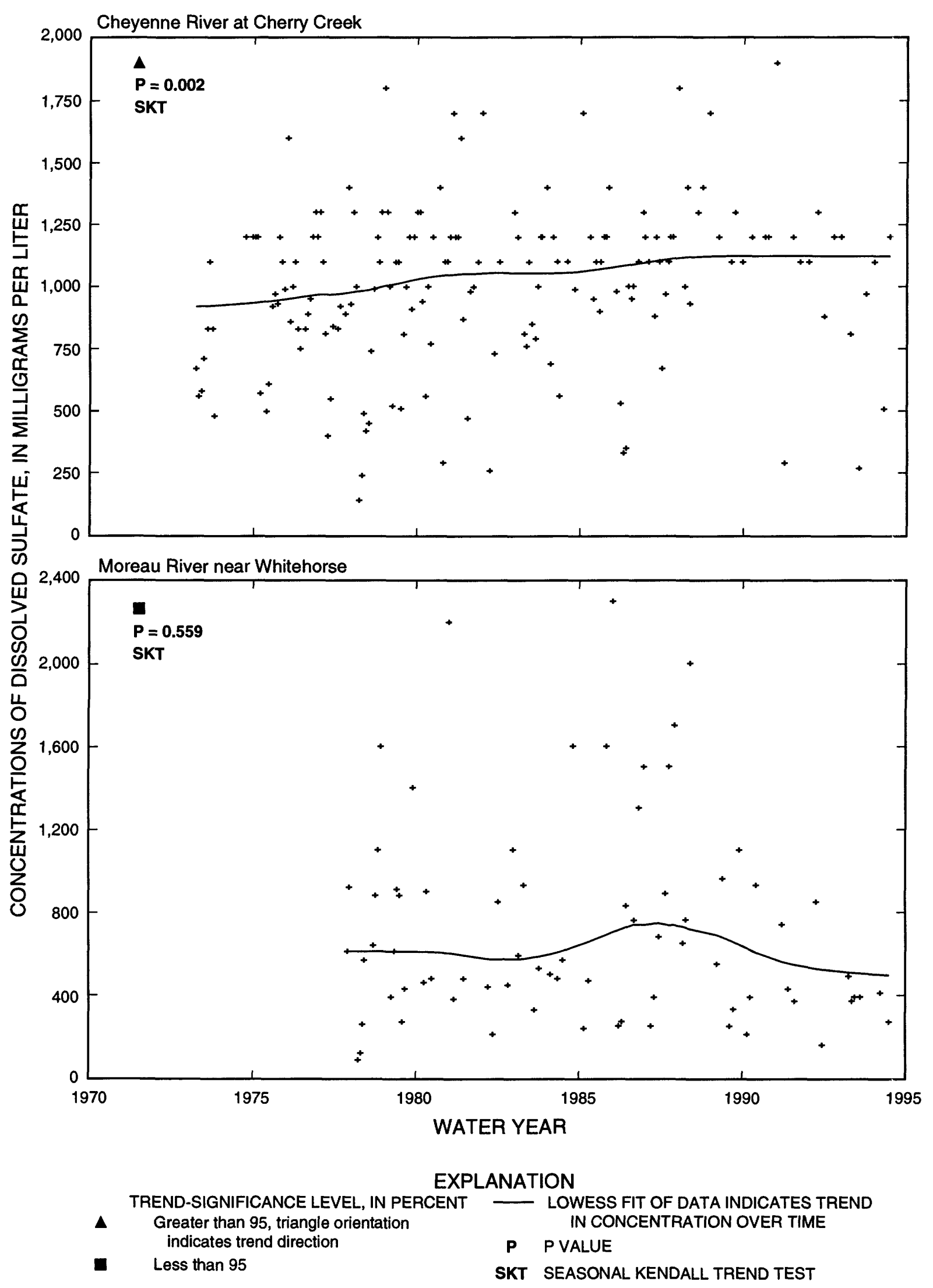

Figure 24. Temporal trends in dissolved sulfate for flow-adjusted concentrations, using the seasonal Kendall test. 


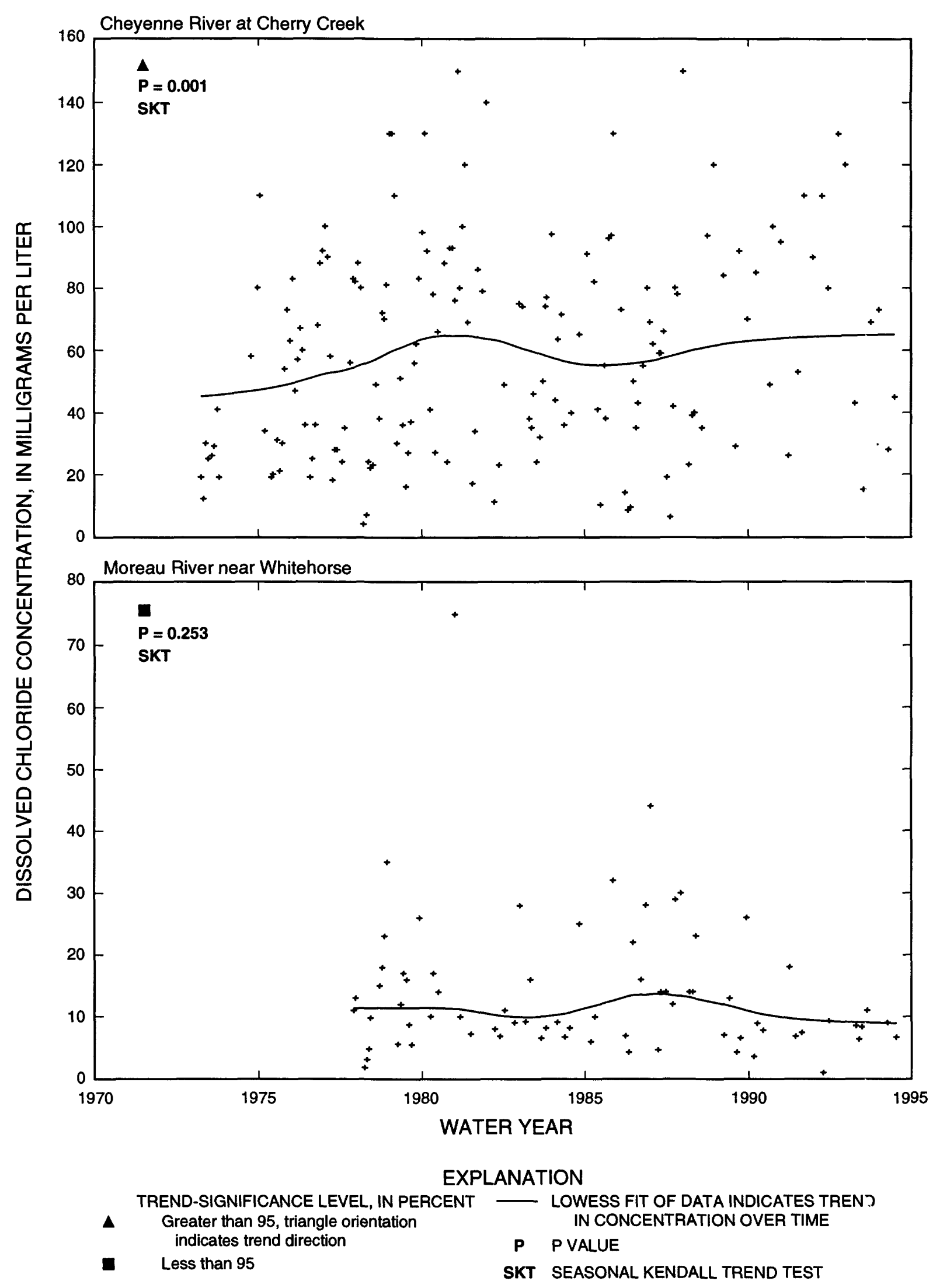

Figure 25. Temporal trends in dissolved chloride for flow-adjusted concentrations, using the seasonal Kendall test. 


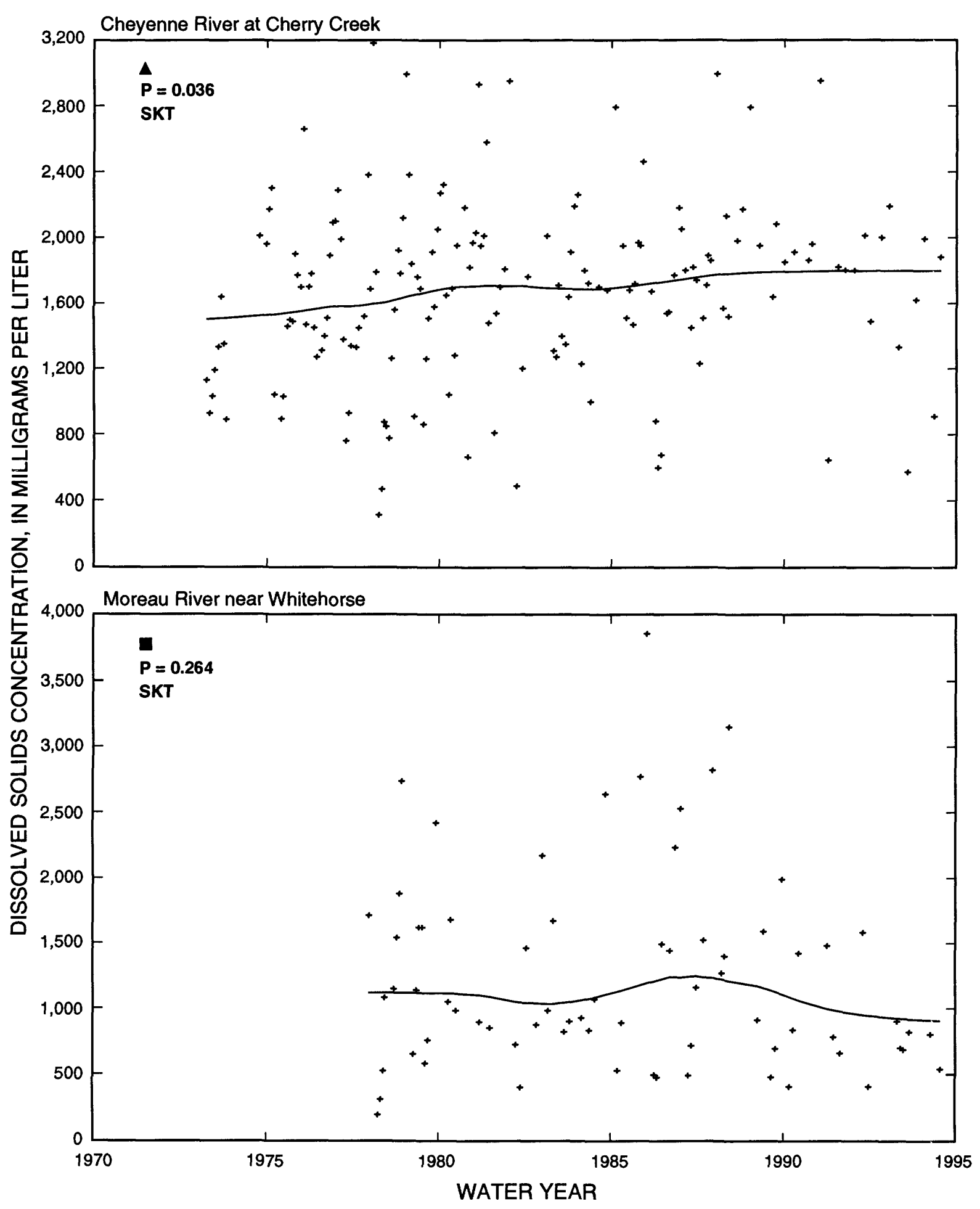

EXPLANATION

TREND-SIGNIFICANCE LEVEL, IN PERCENT — LOWESS FIT OF DATA INDICATES TREND

Greater than 95 , triangle orientation indicates trend direction

Less than 95

P P VALUE

SKT SEASONAL KENDALL TREND TEST

Figure 26. Temporal trends in dissolved solids for flow-adjusted concentrations, using the seasonal Kendall test. 


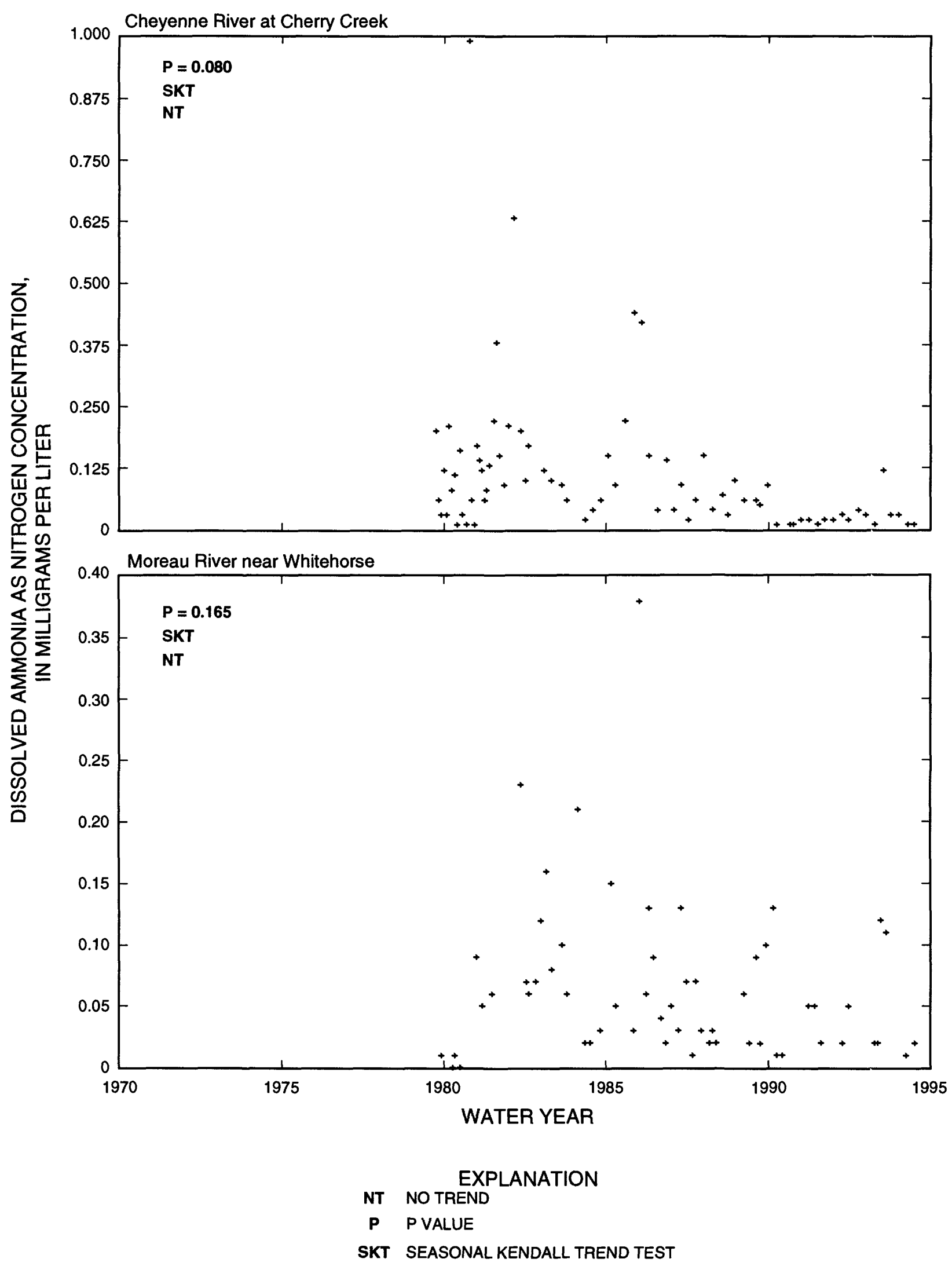

Figure 27. Temporal trends in dissolved ammonia as nitrogen for flow-adjusted concentrations, using the s?asonal Kendall test.

50 Water-Quality Trends for the Cheyenne and Moreau Rivers, Cheyenne River Indian Reservation, South Dak ?ta, $1972-94$ 


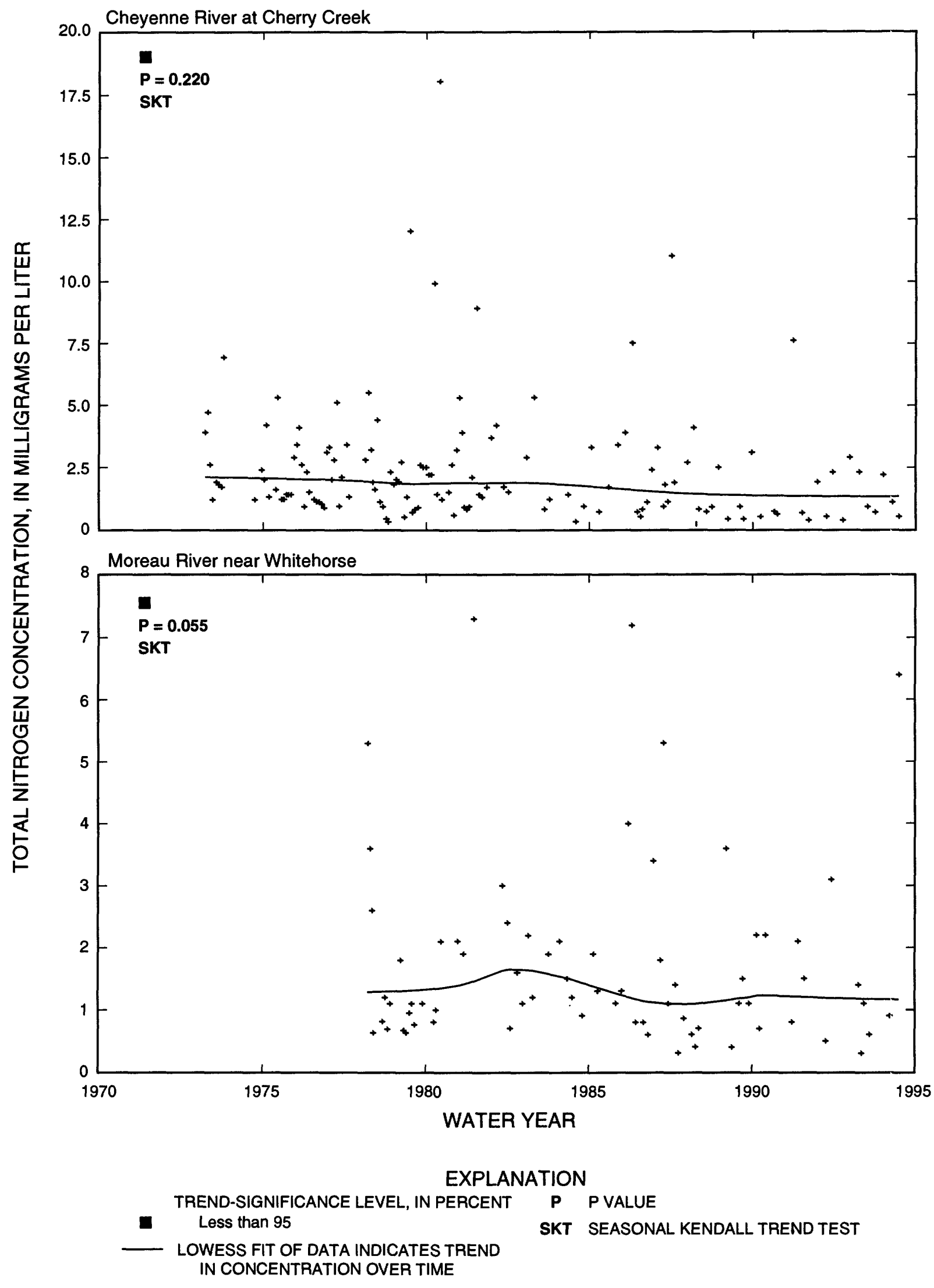

Figure 28. Temporal trends in total nitrogen for flow-adjusted concentrations, using the seasonal Kendall test. 


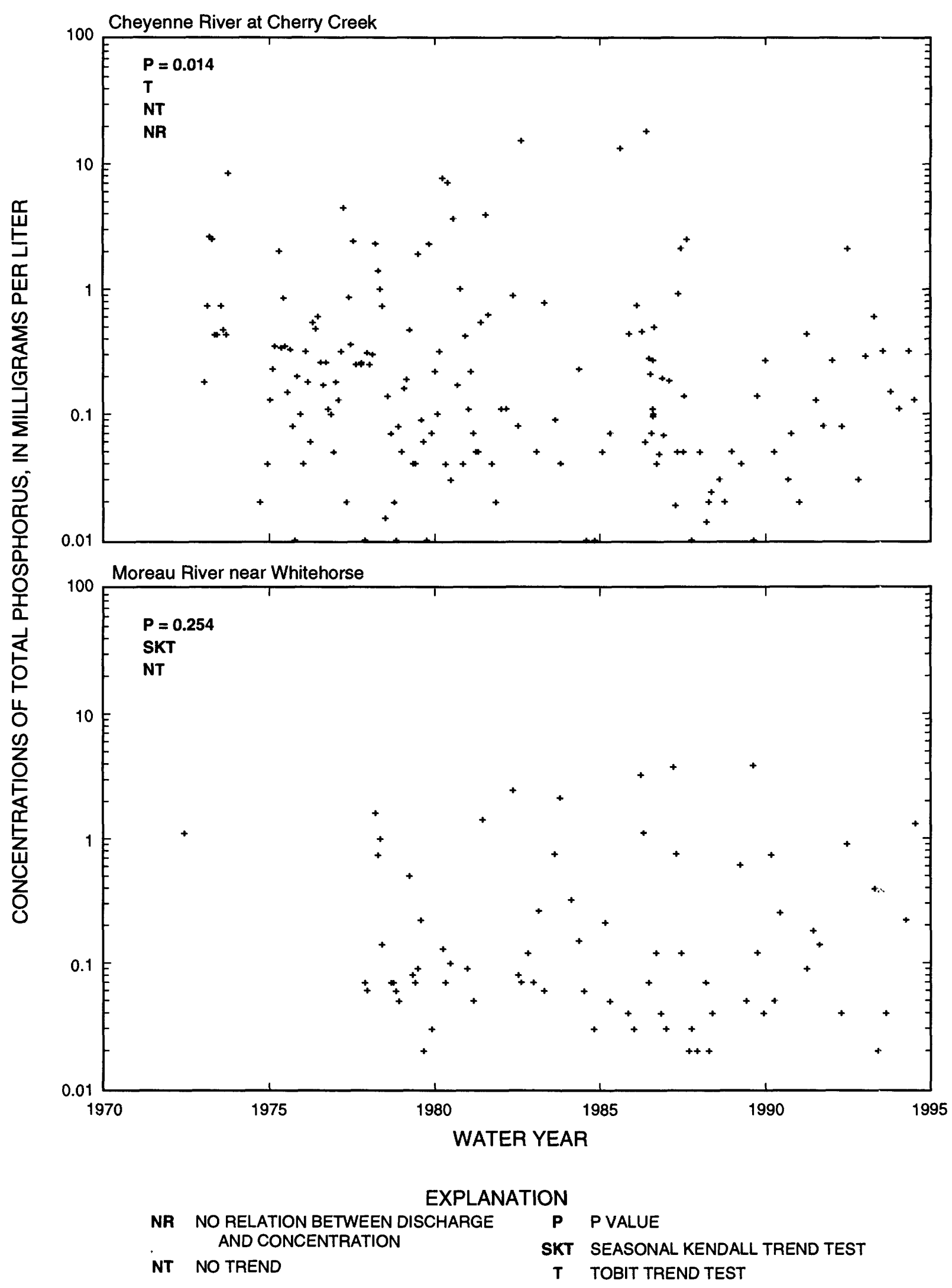

Figure 29. Temporal trends for the Cheyenne River in total phosphorus for raw concentrations, using the -obit test, and for the Moreau River for flow-adjusted concentrations, using the seasonal Kendall test. 


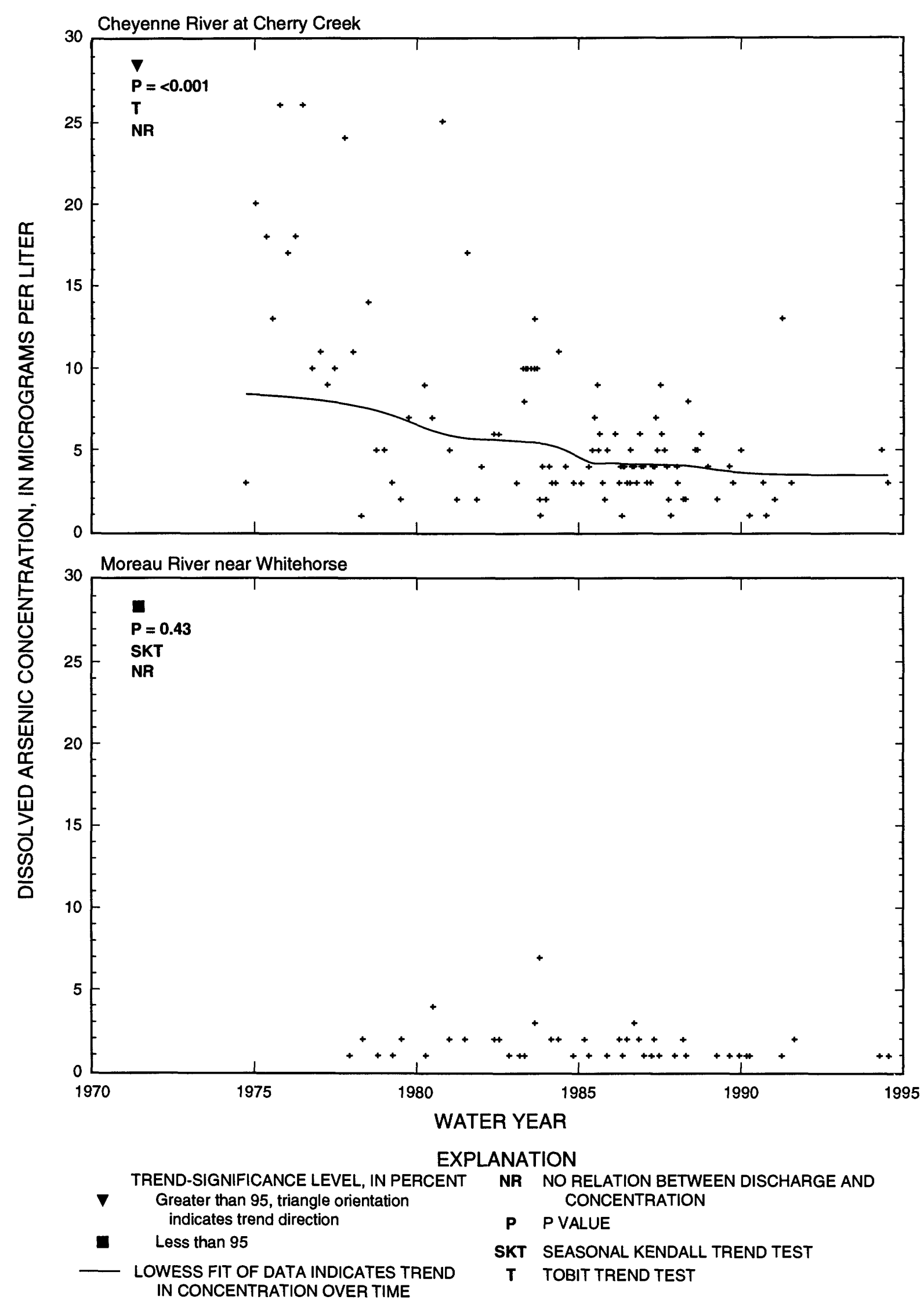

Figure 30. Temporal trends for the Cheyenne River in dissolved arsenic for raw concentrations, using the Tobit test, and for the Moreau River for flow-adjusted concentrations, using the seasonal Kendall test. 


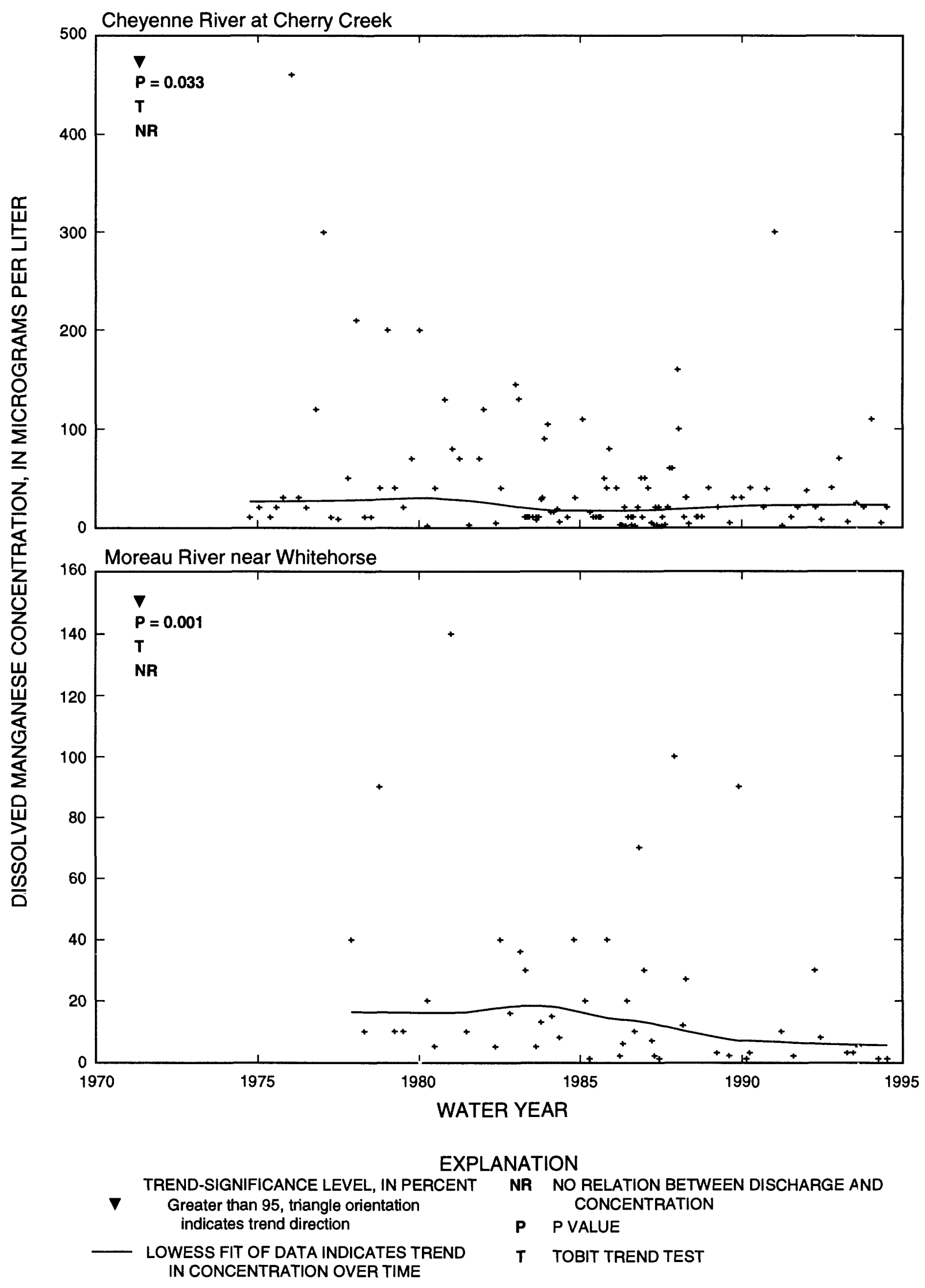

Figure 31. Temporal trends in dissolved manganese for raw concentrations, using the Tobit test. 


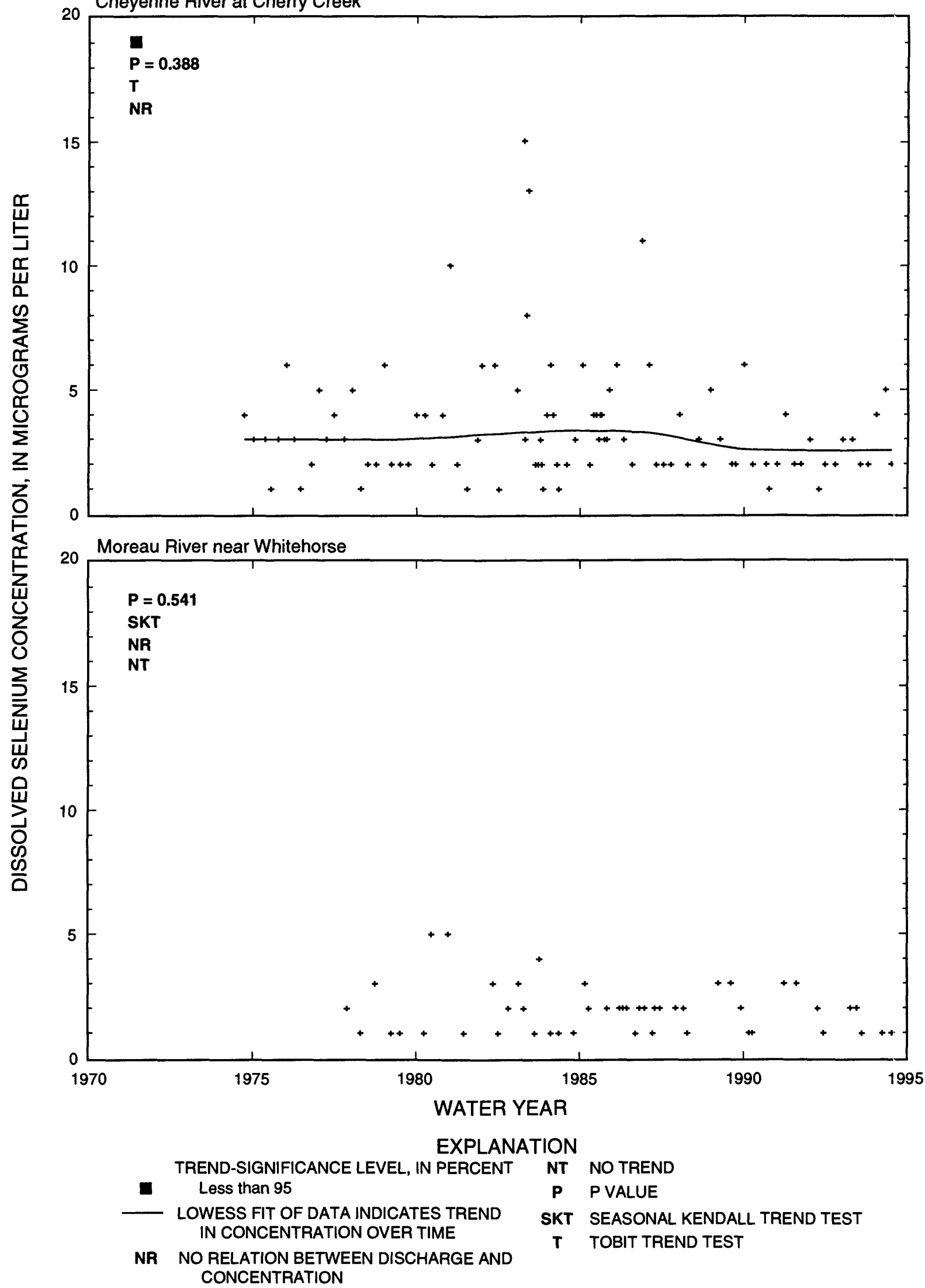

Figure 32. Temporal trends for the Cheyenne River in dissolved selenium for raw concentrations, using the -obit test, and for the Moreau River for raw concentrations, using the seasonal Kendall test. 


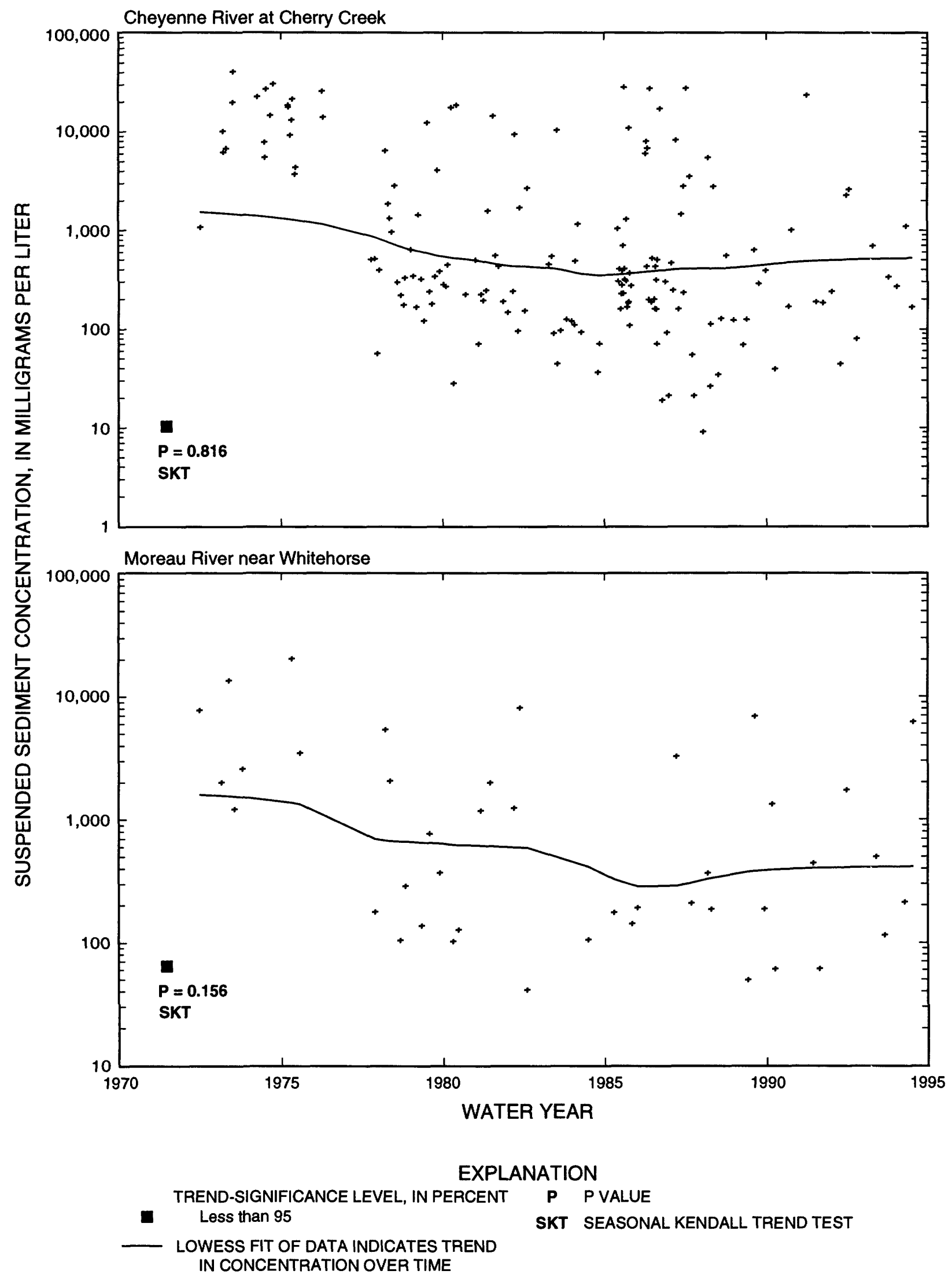

Figure 33. Temporal trends in suspended sediment for flow-adjusted concentrations, using the seasonal Kendall test. 